\author{
UNIVERSIDADE DE SÃO PAULO \\ CENTRO DE ENERGIA NUCLEAR NA AGRICULTURA - CENA/USP
}

\author{
SAMANTA MARIA GOBBO FEDRIZZI
}

Produção de metabólitos antimicrobianos e sideróforos de isolados provenientes de Terra Preta Antropogênica da Amazônia Ocidental 
SAMANTA MARIA GOBBO FEDRIZZI

\section{Produção de metabólitos antimicrobianos e sideróforos de isolados provenientes de Terra Preta Antropogênica da Amazônia Ocidental}

Tese apresentada ao Centro de Energia Nuclear na Agricultura - Universidade de São Paulo, para obtenção do título de Doutor em Ciências.

Área de Concentração: Biologia na Agricultura e no Ambiente.

Orientadora: Prof. Dra. Siu Mui Tsai

Piracicaba - SP 
AUTORIZO A REPRODUÇÃO E DIVULGAÇÃO TOTAL OU PARCIAL DESTE TRABALHO, POR QUALQUER MEIO CONVENCIONAL OU ELETRÔNICO, PARA FINS DE ESTUDO E PESQUISA, DESDE QUE CITADA A FONTE.

Dados Internacionais de Catalogação na Publicação (CIP)

Seção Técnica de Biblioteca - CENA/USP

Fedrizzi, Samanta Maria Gobbo

Produção de metabólitos antimicrobianos e sideróforos de isolados provenientes de Terra Preta Antropogênica da Amazônia Ocidental / Samanta Maria Gobbo Fedrizzi; orientadora Siu Mui Tsai. - - Piracicaba, 2006.

$117 \mathrm{f}$ : : fig.

Tese (Doutorado - Programa de Pós-Graduação em Ciências. Área de Concentração: Biologia na Agricultura e no Ambiente) - Centro de Energia Nuclear na Agricultura da Universidade de São Paulo.

1. 16S rRNA 2. Peptídeo Sintetase Não Ribossômica 3. Policetídeo Sintase 4. Metabólito Secundário 5. Pseudomonina I. Título

CDU 579.22 
À minha família, Ricardo Fedrizzi, marido, companheiro, pai e amor da minha vida. Aos meus filhos Pedro e Lucas, meus tesouros, que são a calma, a serenidade e a luz da minha vida, dedico.

Aos meus pais Nivaldo e Hermínia e minha irmã Sarita Go66o por estarem sempre presentes em todos os momentos da minha vida, ofereço. 


\section{AGRADECIMENTOS}

À Prof ${ }^{\mathrm{a}}$ Dr $^{\mathrm{a}}$ Siu Mui Tsai, pela oportunidade dada para a realização desse projeto, pela orientação segura e amizade que me permite compartilhar e por ter-me guiado, apoiado e auxiliado, me estimulando a crescer profissionalmente, a quem devo total gratidão.

À $\operatorname{Dr}^{\mathrm{a}}$ Maria Estela Stenico, um exemplo de vida e dedicação, agradeço pelo carinho e apoio, por me fazer acreditar que para tudo tem um jeito nessa vida e por permitir compartilhar dessa amizade.

À Prof ${ }^{\mathrm{a}}$ Dr $^{\mathrm{a}}$ Adriana Pinheiro Martinelli, pela amizade, carinho, por todos os esforços e principalmente por ter confiado e acreditado em mim.

Aos técnicos do Laboratório de Biologia Molecular e Celular, José Elias Gomes, Fábio Rodrigo Sanches Duarte, Wagner Picinini e Francisco Montrazi, por todos os "galhos quebrados", por todos os ensinamentos, por todo carinho e amizade.

Aos amigos do Laboratório de de Biologia Molecular e Celular: Daniela Campos, Othon Abrahão, Luciana Ferreira, Fabiana Canavan, Rafael Medau, Jeanedy Pazinato, Ezio Nalim, Ludmila Campos, Juliana Martineli, Carlos Garcia, Ricardo Yara e Bianca Furlan que me acolheram e me ajudaram na execução do meu trabalho e mais que isso pela nossa amizade. Valeu.....

Á amiga Camila Patreze, pela paciência e cooperação na finalização deste trabalho. 
À Caroline Souza Pamplona da Silva pela colaboração e apoio durante o desenvolvimento deste trabalho.

Aos funcionários do Laboratório de Nutrição Animal: Maria Regina S. R. Pessanha, Lécio Ap. Castilho, Joaquim Everaldo M. dos Santos e Silvana Pousa Maziero pela amizade e pelo auxílio técnico e científico em diferentes etapas da minha vida.

Às bibliotecárias Marília R. G. Henyei pelo grande trabalho que teve em me auxiliar nas correções referente a elaboração da tese.

À Cláudia Márcia de F. Corrêa, Neuda Fernandes de Oliveira, Maria Regina Silveira Rodrigues (in memorian), Alzira Ferraz Adão por todo carinho e principalmente por sempre encontrarem uma solução para os problemas.

Ao Centro de Energia Nuclear na Agricultura por permitir a realização desta pesquisa.

À CAPES, pela concessão de bolsa de estudos e a oportunidade de iniciar a minha formação científica.

Ao Conselho Nacional de Desenvolvimento Científico e Tecnológico-CNPQ por conceder a minha bolsa de estudo bem como todo o auxílio técnico.

A todas as pessoas que passaram pela vida durante essa longa jornada que, de alguma forma contribuíram para o desenvolvimento desse projeto.

A Deus, por estar sempre presente na minha vida em todos os momentos...

Muito Obrigada!!!!! 
"Por vezes sentimos que aquilo que fazemos não é senão uma gota de água no mar. Mas o mar seria menor se lhe faltasse uma gota".

(Madre Teresa de Calcutá) 


\section{RESUMO}

\section{Produção de metabólitos antimicrobianos e sideróforos de isolados provenientes de Terra Preta Antropogênica da Amazônia Ocidental}

Os microrganismos atraem considerável atenção por serem uma fonte de compostos biotecnológicos e farmacêuticos. Diversos produtos naturais peptídicos produzidos por fungos e bactérias são sintetizados por grandes enzimas, conhecidas como peptídeo sintetase não ribossômica (NRPS) e policetídeo sintase (PKS). A bioprospecção dos microrganismos isolados do solo de Terra Preta Antropogênica (TPA) da Amazônia Ocidental é de grande importância para o conhecimento deste bioma tropical. Este estudo correlacionou a presença de sideróforos e de compostos antimicrobianos produzidos pelos microrganismos isolados de TPA e dos solos adjacentes com a presença dos genes que codificam para NRPS e PKS. Linhagens bacterianas foram isoladas das amostras do solo coletadas de 10, 20 e $40 \mathrm{~cm}$ de profundidade. Os isolados foram cultivados em meio líquido específico por 2 dias a $28^{\circ} \mathrm{C}$. Um total de 143 isolados foi testado para a atividade de sideróforo e para isso, as linhagens foram inoculadas em um meio com baixa concentração de ferro (MM9) contendo o complexo cromoazurol $\mathrm{S}-\mathrm{Fe}_{3}$. Do total, 72 isolados apresentaram reação positiva para a produção de sideróforo. O DNA genômico dos isolados foi extraído e a amplificação por PCR foi realizada usando iniciadores específicos para NRPS e PKS. Os resultados mostraram que quinze isolados apresentaram o gene que codifica para NRPS, vinte isolados para PKS e somente dez isolados apresentaram ambos os genes. A presença de genes de NRPS e PKS em 31\% dos isolados testados sugere que a produção dos sideróforos possa ocorrer pela via não ribossomal. Dois isolados foram selecionados para estudos de identificação e caracterização dos compostos. O isolado TP11 foi identificado como Pseudomonas putida através de seqüenciamento do $16 \mathrm{~S}$ rRNA e apresentou resultado negativo para hidroxamato e catecol, sugerindo que o tipo de sideróforo não possui nenhum destes grupos funcionais. $\mathrm{O}$ isolado TP16 foi identificado como Pseudomonas putida e apresentou produção de sideróforo do tipo catecol e hidroxamato, sugerindo a produção de mais de um sideróforo. Além disso, esta linhagem produziu um composto antimicrobiano, com atividade de sideróforo identificado por espectrometria de massas como pseudomonina com massa molar de $330 \mathrm{Da}$.

Palavras-chave: 16S rRNA; Peptídeo Sintetase Não Ribossômica; Policetídeo Sintase; Metabólito Secundário; Pseudomonina. 


\section{ABSTRACT \\ Antimicrobial metabolites and siderophore produced by strains from Anthropogenic Dark Earth of the Occidental Amazon}

Microorganisms have attracted considerable attention as a source for biotechnological and pharmaceutical agents. Several peptidic natural products synthesized by fungi and bacteria are assembled by large enzymes, referred as nonribosomal peptide synthetase (NRPS) and polyketide synthase (PKS). Bioprospection of microorganisms isolated from Anthropological Dark Earth soil of Brazilian Occidental Amazon is of great importance to the knowledge of this tropical biome. This study aimed to correlate the presence of siderophores and antimicrobial compounds produced by microorganisms isolated from Dark Earth and adjacent soils of Brazilian Amazon with the presence of genes encoding NRPS and PKS. Bacterial strains were isolated from soil samples collected at 10,20 and $40 \mathrm{~cm}$ depth. The isolates were grown in specific liquid medium for $2 \mathrm{~d}$ at $28^{\circ} \mathrm{C}$. A total of 143 isolates were screened for siderophore activity and for this, bacterial strains were inoculated on plates containing an iron-limited medium (MM9) amended with a chromeazurol $\mathrm{S}-\mathrm{Fe}_{3}$ complex. From the total, seventy-two isolates showed positive reaction for siderophore production. Genomic DNA of the isolates was extracted and PCR amplification was carried out using specific primers for NRPS and PKS. The results showed that fifteen isolates presented NRPS, twenty isolates presented PKS and only ten isolates showed both genes. The presence of NRPS and PKS genes in $31 \%$ of the isolates tested suggests that production of siderophores may occur by a nonribosomal pathway. Two isolates were selected for further studies. Isolate TP11 was identified as Pseudomonas putida by $16 \mathrm{~S}$ rDNA sequencing analysis and was negative for hydroxamate and catechol, suggesting that the siderophore type has no hydroxamate- or catechol-type functional groups. The isolate TP16 was identified as Pseudomonas putida and showed the production of catechol and hydroxamate siderophore-type, suggesting the production of more than one siderophore. In addition, this strain produced an antimicrobial compound, with siderophore activity identified through mass spectrometry as pseudomonine with a molar mass of $330 \mathrm{Da}$.

Keywords: 16S rRNA; Non-ribosomal Peptide Synthetase; Polyketide Synthase; Secondary Metabolite; Pseudomonine. 


\section{LISTA DE FIGURAS}

Figura 1- Mapa da localização de Terra Preta na Amazônia.............................. 25

Figura 2- $\quad$ Presença de artefatos líticos em TPA................................................ 26

Figura 3- $\quad$ Ativação de aminoácidos na síntese peptídica pela via ribossomal e não-ribossomal........................................................................ $\quad 30$

Figura 4- Classe dos sideróforos................................................................ 35

Figura 5- Imagem aérea da localização dos solos de Terra Preta e adjacente

Figura 6- Áreas de coleta de solos de TPA e solo adjacente.

Figura 7- Teste do CAS-agar para análise em espectrometria de massas.

Figura 8- Eletroforese em gel de agarose $1 \%$ com produtos de amplificação para o gene ribossomal $16 \mathrm{~S}$ rRNA

Figura 9- Eletroforese em gel de agarose 1,7\% com produtos de digestão enzimática com a endonuclease Taq I após a amplificação do gene $16 \mathrm{~S}$ rRNA

Figura 10- Eletroforese em gel de agarose 1,7\% com produtos de digestão enzimática com as endonucleases $R s a$ I e $M s p$ I após a amplificação do gene $16 \mathrm{~S}$ rRNA.

Figura 11- Porcentagem de isolados seqüenciados de solos TPA e adjacente.

Figura 12- Árvore filogenética baseada na seqüência do gene 16S rRNA de isolados de TPA e solo adjacente

Figura 13- Produtos amplificados para o gene NRPS e PKS.. 
Figura 14- Distribuição de genes que codificam para NRPS e

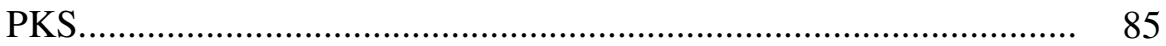

Figura 15- Crescimento das linhagens em meio de cultivo contendo o complexo CAS..........

Figura 16- Produção de sideróforos (CAS-agar) de isolados de TPA e solo adjacente

Figura 17- Espectros de massas em modo positivo de ionização por "electrospray"”, (ESI).....

Figura 18- Espectros MS/MS de dissociação induzida por colisão (CID)

Figura 19- Teste de bioensaio

Figura 20- Curva de crescimento de $P$. putida TP16 e produção sideróforo.

Figura 21- Detecção de sideróforo em sobrenadante de $P$. putida TP16 em solução de CAS

Figura 22- CCD dos extratos de P. putida TP16 - comprimento de onda 366 $\mathrm{nm}$

Figura 23- CCD dos extratos de $P$. putida TP16 - comprimento de onda $254 \mathrm{~nm} 97$

Figura 24- Espectros de electrospray (ESI) de pseudomonina em modo positivo

Figura 25- Estrutura química do sideróforo pseudomonina.

Figura 26- Esquema de fragmentação para o íon $\mathrm{m} / \mathrm{z}$ 331 


\section{LISTA DE TABELAS}

Tabela 1- Sideróforos produzidos por bactérias e fungos.................................... 40

Tabela 2- $\quad$ Isolados de bactérias e localização...................................................... 46

Tabela 3- Seqüências de oligonucleotídeos internos para amplificação do

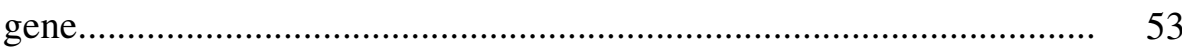

Tabela 4- Iniciadores de reação que foram utilizados na amplificação por PCR.. 56

Tabela 5- Análise de polimorfismo do DNA genômico...................................... 70

Tabela 6- Identificação dos isolados através do seqüenciamento do gene $16 \mathrm{~S}$

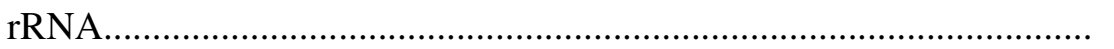

Tabela 7- População de bactérias encontradas em TPA e solo

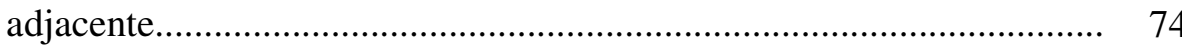

Tabela 8- Identificação dos isolados que apresentaram os genes que codificam NRPS e PKS e produção de sideróforos............................................ 78

Tabela 9- Distribuição dos isolados em diferentes profundidades em TPA e solo

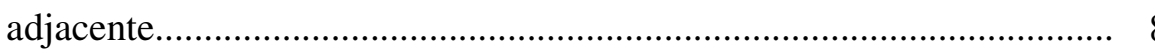

Tabela 10- Produção de sideróforos do tipo catecol e hidroxamato........................ 88

Tabela 11- Rfs das frações dos extratos................................................................ 96 


\section{LISTA DE ABREVIATURAS}

A

$\mathrm{A}_{\text {ref }}$

ARDRA

AS

CAS

CCD

CID

DNA

D.O.

ESI

HDTMA

$m / z$

$\mathrm{MM}$

NRPS

ORF

$\mathrm{pb}$

PCR

PKS

Q-TOF

RNA

TPA
Absorbância da amostra

Absorbância do controle

“Amplified Ribosomal DNA Restriction Analysis" (Análise de

restrição de DNA ribossomal amplificado)

Ácido Salicílico

Cromoazurol S

Cromatografia em camada delgada

“Collision-induced dissociation” (Dissociação Induzida Por Colisão)

Ácido Desoxirribonucléico

Densidade Óptica

"Electrospray ionization” (Ionização por "Electrospray”)

Hexadeciltrimetilamônio

Razão Massa Carga

Massa Molecular

"Non ribosomal peptide synthetase" (Peptídeo Sintetase não ribossômica)

“Open Reading Frames” (Quadro aberto de leitura)

Pares de Base

"Polymerase Chain Reaction” (Reação de polimerase em cadeia)

"Poliketyde synthase" (Policetídeo Sintase)

"Quadrupole - time of flight" (Quadrupolo - Tempo de Vôo)

Ácido Ribonucléico

Terra Preta Antropogênica 


\section{SUMÁRIO}

Página

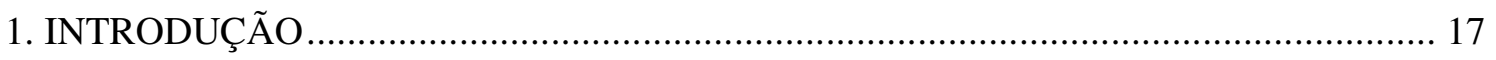

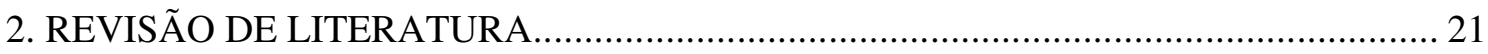

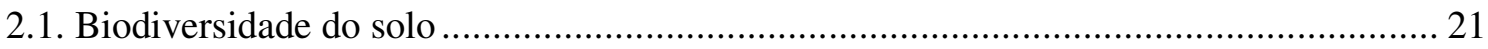

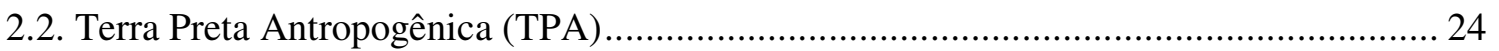

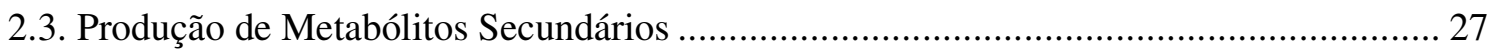

2.4. Biossíntese de Peptídeos não ribossômicos ................................................................ 28

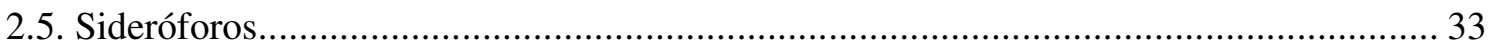

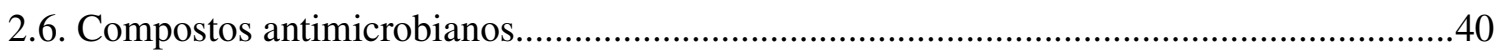

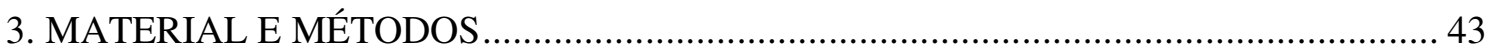

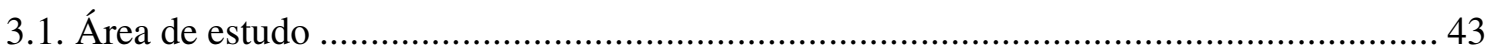

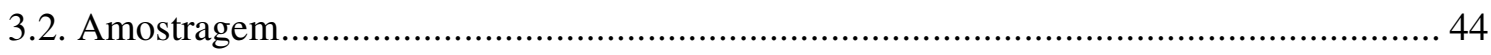

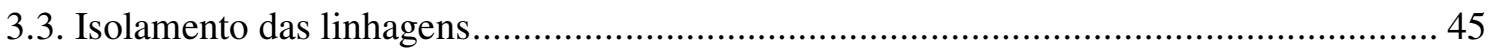

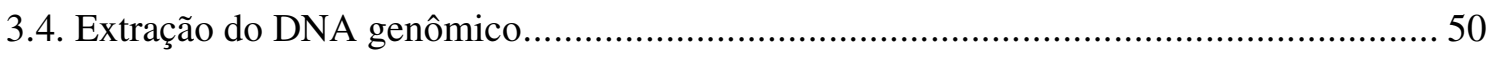

3.5. Amplificação do gene que codifica o 16S rRNA …................................................ 50

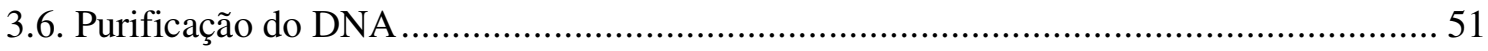

3.7. Análise de restrição do DNA ribossomal amplificado (ARDRA) ..................................52

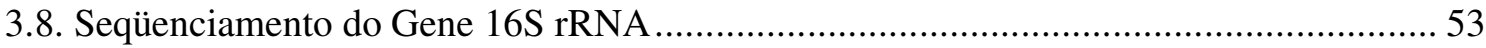

3.9. Processamento e análise filogenética das seqüências ................................................. 54

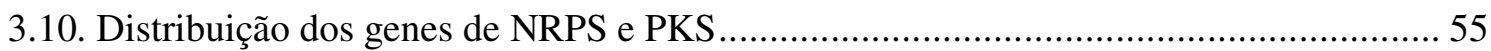


3.11. Produção de sideróforo em meio Sólido

3.12. Detecção de sideróforo em solução pelo método do CAS …...................................... 57

3.13. Análise de sideróforos - propriedades químicas .................................................. 57

3.13.1. Análise pelo método de CSÁKY (1948)........................................................ 58

3.13.2 Análise pelo método de ARNOW (1937) .................................................. 58

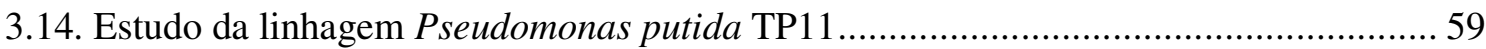

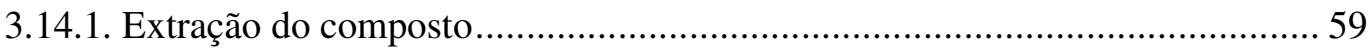

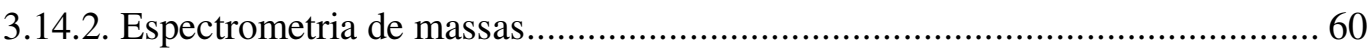

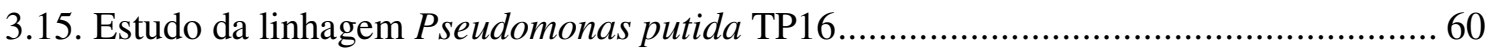

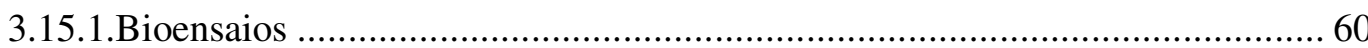

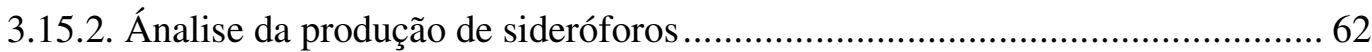

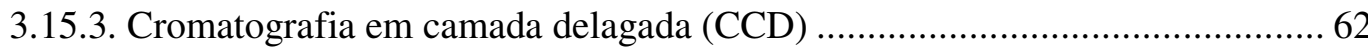

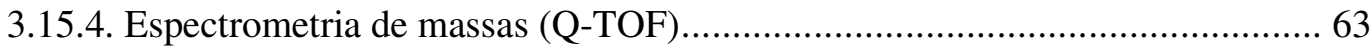

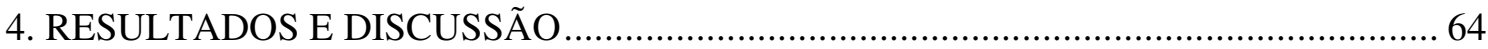

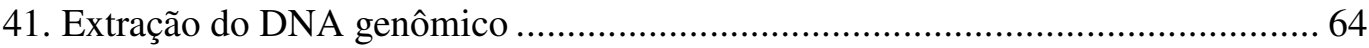

4.2. Amplificação do gene que codifica o 16S rRNA .................................................. 64

4.3. Análise de restrição do DNA ribossomal amplificado (ARDRA) ....................... 67

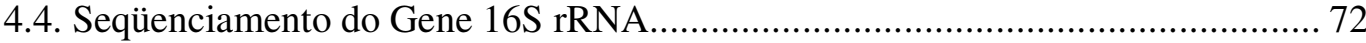

4.5. Processamento e análise filogenética das seqüências ...................................... 75

4.6. Distribuição dos genes que codificam para NRPS e PKS ................................. 77

4.7. Produção de sideróforo em meio Sólido ........................................................... 86 
4.8. Análises pelos métodos bioquímicos de Csácky e Arnow .................................. 88

4.9. Estudo da linhagem Pseudomonas putida TP11 ............................................ 89

4.10 Estudo da linhagem Pseudomonas putida TP16 ............................................ 91

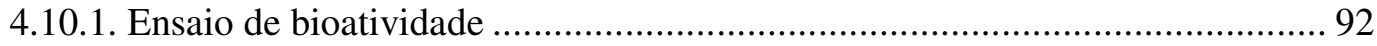

4.10.2. Produção de sideróforo pela linhagem P. putida TP16 .............................. 93

4.10.3. Cromatografia em Camada Delgada ............................................................. 95

4.10.4. Espectrometria de massas...................................................................... 98

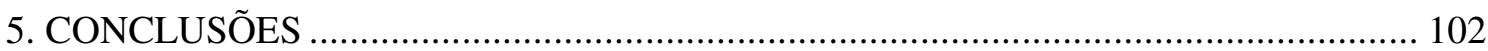

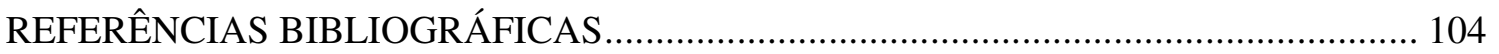




\section{INTRODUÇÃO}

As bactérias são organismos procarióticos pertencentes aos Domínios Bacteria, vivem nos mais variados ecossistemas da Terra. As populações microbianas são as mais diversas geneticamente, indicando que elas tiram proveito de qualquer nicho encontrado em seu ambiente, realizando assim, os mais variados processos para obtenção dos nutrientes necessários para o seu desenvolvimento.

Os microrganismos sobrevivem em um ambiente bastante competitivo, sendo responsáveis por uma grande quantidade de processos biogeoquímicos e de uma certa forma, controlando os ecossistemas no qual fazem parte. Uma grande diversidade microbiana pode ser encontrada em quantidades pequenas de solo, podendo sobreviver em várias situações ambientais diferentes onde também são responsáveis pela fertilidade do solo. Um maior conhecimento sobre essa diversidade se faz necessário para uma melhor compreensão das funções da comunidade microbiana nos solos e as suas interações com outros componentes da biodiversidade, como por exemplo, os animais e as plantas.

A Floresta Amazônica é um dos maiores recursos naturais do mundo graças à sua biodiversidade que ainda precisa ser melhor conhecida e explorada. Populações ribeirinhas utilizam o solo para plantações há centenas de anos e sua fertilidade continua a mesma. Esses solos conhecidos como Terra Preta Antropogênica (TPA) ocorre somente em sítios arqueológicos na região Amazônica. Ela se estende da Cordilheira dos Andes até a Ilha de Marajó. A sua biodiversidade microbiológica é muito pouco conhecida e daí a importância em catalogar esses microrganismos. 
A TPA é conhecida pela sua grande fertilidade, sem adição de insumos ou fertilizantes (GLASER et al., 2001). Sabe-se que a fertilidade do solo é resposta da diversidade microbiológica da comunidade local, onde apenas uma pequena porcentagem é conhecida (HACKL et al., 2004). A TPA contribui para a agricultura de subsistência das populações ribeirinhas, as quais a utilizam para plantação de várias monoculturas como mamão, feijão, etc. Estes solos de origem antrópica foram enriquecidos em nutrientes, provavelmente pelo manejo de restos orgânicos e do fogo pelas populações pré-colombianas. Estima-se que $1 \mathrm{~cm}$ de TPA leve pelo menos 10 anos para se formar. As TPAs mostram tipicamente um horizonte A espesso e de cor escura, elevados teores de fósforo, cálcio e alguns micronutrientes, como o manganês e o zinco (SOMBROEK, 1966; KERN; KÄMPF, 1989). Apresentam também teores de matéria orgânica estável superiores aos solos adjacentes (SMITH, 1980; GLASER et al., 2001). Essa estabilidade é questionada se isso seria um resultado das características mineralógicas desses solos orgânicos ou deve-se ao carbono orgânico, já que a quantidade de carvão vegetal é a maior diferença que existe entre a TPA e os solos adjacentes. Neste último, ocorre a rápida decomposição da matéria orgânica, devido às altas temperaturas, precipitações elevadas e a deficiência de minerais estáveis (GLASER et al., 2001).

A TPA possui também maior atividade biológica que os solos adjacentes originais, onde não houve ação antrópica (KERN; KÄMPF, 1989). Outra característica da TPA é a sustentabilidade de sua fertilidade, sendo os microrganismos do solo fundamentais para esse processo.

A grande atividade biológica e o material orgânico estável encontrado nas TPAs podem indicar um tipo de solo com alta diversidade de microrganismos, o que constitui em uma fonte de germoplasma microbiano. Entretanto, ainda não se tem conhecimento da microbiota e 
sobretudo da diversidade das comunidades e estrutura microbiana presentes em TPA. O conhecimento desta biodiversidade poderá melhorar o entendimento das funções destas comunidades microbianas, além de se conhecer as interações com outros componentes desta diversidade biológica. Isso proporcionará benefícios econômicos e estratégicos, como a descoberta de microrganismos potencialmente exploráveis.

Alguns microrganismos do solo são responsáveis pela produção de vários metabólitos secundários que exercem várias funções, como por exemplo: antibióticos, anticancerígenos, imunosupressores, componentes antifúngicos, inibidores enzimáticos, agentes antiparasitários, herbicidas, inseticidas e promotores de crescimento (OMURA, 1992). Objetivando um melhor aproveitamento desses microrganismos potencialmente exploráveis para vários processos biotecnológicos, as indústrias tentam se beneficiar da descoberta de novos metabólitos. Os metabólitos produzidos por alguns microrganismos se tornaram alvo para a produção de novos antibióticos e agentes terapêuticos, probióticos, biorremediação de poluentes, entre outros. Também de muito interesse, a melhoria da capacidade microbiana para a fertilização dos solos e para a despoluição das águas tornou-se alvo de estudos.

A Floresta Amazônica por ser um dos maiores nichos ecológicos do mundo, abrigando uma enorme quantidade de animais, plantas e microrganismos, possui uma biodiversidade enorme, principalmente no solo sendo alvo de exploração para a produção desses metabólitos, tanto na indústria internacional farmacêutica quanto estética. Por isso, a importância em se conhecer os microrganismos do solo tem-se intensificado.

Alguns metabólitos podem ser produzidos, por exemplo, em condições de baixa concentração de ferro no solo. Embora o ferro seja abundante em solos aerados (1 a 6\%), é freqüentemente indisponível para as plantas devido a sua solubilidade, que é dependente do 
pH e controlada pela baixa solubilidade dos óxidos de ferro. O ferro livre, em ambientes aeróbios, está presente a uma concentração de aproximadamente $10^{-18} \mathrm{M}$ a $\mathrm{pH} 7$ (BIEDERMANN; SCHINDLER, 1957). A baixa solubilidade do ferro se torna um problema para os microrganismos que requerem esse metal e vivem em um ambiente aeróbio. Para combater esta baixa solubilidade, os microrganismos desenvolveram um sistema de transporte com elevada afinidade por ferro, moléculas de baixa massa molar, conhecidos como sideróforos (NEILANDS, 1984).

Muitos metabólitos secundários produzidos por fungos e bactérias são produzidos por enzimas multifuncionais denominadas de peptídeo sintetase não ribossômica (NRPS) e as policetídeos sintases (PKS). Alguns tipos de enzimas são modulares e estão envolvidas na produção de sideróforos e antibióticos. Essas enzimas multifuncionais envolvidas na biossíntese não-ribossômica de antibióticos peptídicos (KLEINKAUF; VON DÖHREN, 1996; STACHELHAUSS; MARAHIEL, 1995) possuem sequiências conservadas envolvidas em reações parciais de formação de adenilatos, ativação de intermediários na forma de tioéster, condensação e em alguns casos, modificação de aminoácidos por metilação e epimerização.

A bioprospecção dos microrganismos isolados do solo de Terra Preta Antropogênica (TPA) da Amazônia Ocidental é de grande importância para o conhecimento deste bioma tropical. Este estudo correlacionou a presença de sideróforos e de compostos antimicrobianos ativos assim como de genes que codificam para NRNRPS e PKS, produzidos pelos microrganismos isolados de TPA dos municípios de Rio Preto da Eva e de Presidente Figueiredo e de seus solos adjacentes. 


\section{REVISÃO DA LITERATURA}

\subsection{Biodiversidade do solo}

Devido ao fato dos microrganismos serem os mais diversos e abundantes organismos da Terra (TORSVIK et al., 2002; VENTER et al., 2004), a distribuição da diversidade microbiana precisa ser melhor estudada. Com o advento da análise do DNA ribossomal, a caracterização de comunidades bacterianas tornou-se mais acessível, devido a este ser um método de análise rápido (PACE, 1997; JACKSON et al., 2002). A composição microbiana de uma comunidade é mais efetivamente elucidada por este método do que o método convencional de cultivo (SMITH et al., 2006).

Bactérias do solo são organismos essenciais para a comunidade biótica em florestas naturais e são responsáveis pelo funcionamento dos ecossistemas e por participarem de vários processos de transformação de nutrientes (HACKL et al., 2004).

Os microrganismos do solo são responsáveis pela degradação de toda matéria morta do solo. Através da degradação de diferentes elementos ocorrem transformações em uma variedade de biomoléculas e vários metabólitos secundários são liberados via degradação microbiológica realizadas por várias enzimas (DUBEY et al., 2006) ou processos ainda desconhecidos.

Nos últimos 50 anos, vários metabólitos secundários foram utilizados e continuam sendo em várias áreas como na medicina, indústria e na agricultura. São utilizados na produção de antibióticos, antitumorais, componentes antifúngicos, antiparasitários, inseticidas e 
promotores de crescimento. Os microrganismos do solo têm sido uma fonte de pesquisa para produção de produtos naturais. Através de cultura in vitro desses microrganismos, é possível o estudo de compostos bioativos. Esses estudos com a comunidade da microbiota do solo estão divididos em duas áreas: 1) estudo da diversidade, incluindo isolamento, identificação e quantificação dos microrganismos em vários ecossistemas e 2) atividade microbiológica, como eles contribuem para a manutenção da atividade do solo como, por exemplo, no ciclo biogeoquímico (XU, 2006).

Cada vez mais tornam-se necessários métodos rápidos de análises para a diversidade das comunidades microbiológicas. LAMBAIS et al. (2006), estudaram a biodiversidade microbiana da folha de três espécies de árvores da Floresta Amazônica. Uma varredura das amostras de folhas indicaram uma diversidade de 95 a 671 espécies por amostra.

MARTIN-LAURENT et al. (2001) testaram três diferentes tipos de extração de DNA total do solo comparando a diversidade encontrada através das técnicas RISA (Ribossomal Intergenic Spacer Analysis) e ARDRA (Amplified Restriction Fragment Length Polymorfism). Os resultados indicaram que os métodos de extração de DNA total do solo podem interferir na abundância de microrganismos como na composição das comunidades nativas.

Vários estudos indicaram a importância da floresta Amazônica não só na biodiversidade de microrganismos como também na interferência nos ecossistemas (ERWIN, 1988). BORNEMAN e TRIPLETT (1997) analisaram os solos de uma região Amazônica através de extração de DNA do solo e utilizando a técnica RISA, elaboraram uma árvore filogenética e mostraram uma imensa variedade de microrganismos presentes em pequenas quantidades de 
solo, sendo que $18 \%$ das seqüências não puderam ser classificadas em nenhum reino conhecido. Cinco seqüências formaram uma classe que pode ser representada por um novo grupo dentro da classe Proteobacteria. Análises do espaçador intergênico do RNA ribossomal indicaram diferenças significativas na população microbiana dos solos naturais da floresta e dos solos adjacentes.

HACKL et al. (2004) avaliou a diversidade microbiológica em três tipos de solos de florestas naturais da Áustria. Os dados indicaram que cada tipo de população microbiana é diferente entre os tipos de amostras de solo.

Novas técnicas de biologia molecular têm ajudado a demonstrar a diversidade de microrganismos no solo. No estudo de FIERER e JACKSON (2006) é apresentado uma descrição em escala continental das comunidades bacterianas do solo e os fatores ambientais que influenciam sua biodiversidade. Foram coletadas 98 amostras de solo da América do Sul e do Norte e usado uma varredura do DNA ribossomal, que é um método para comparar a composição da comunidade bacteriana e a diversidade quantitativamente por sítios de coleta. A diversidade e riqueza das comunidades bacterianas do solo foram diferentes em cada ecossistema estudado e estas diferenças poderiam ser explicadas em grande parte através de pH do solo. A diversidade bacteriana foi maior em solos neutros e menor em solos ácidos. Já os solos da Amazônia Peruana foram os mais ácidos e com menos diversidade. Esses resultados sugerem que a biogeografia microbiana seja principalmente controlada através de variáveis edáficas que fundamentalmente diferem da biogeografia dos seus organismos.

Resultados de medições realizadas no solo indicaram que a intensificação da agricultura tem levado a uma diminuição da biodiversidade do solo. As mudanças nas práticas de 
agricultura afetam essa biodiversidade, mas o monitoramento dessas práticas agrícolas e pesquisas recentes tentam conciliar esses problemas como, por exemplo, o uso de pesticidas. A diminuição da heterogeneidade ecológica em escalas espacial e temporal são conseqüências da intensificação da agricultura multivariada, entretanto pesquisas futuras fornecerão meios de recriar a heterogeneidade do solo que é a chave para restaurar e sustentar a biodiversidade em sistemas agrícolas (BENTON; AYALA, 2003).

A quantidade e a composição da biomassa microbiológica do solo são sensíveis particularmente a alterações ambientais do solo. Esses parâmetros da biomassa microbiológica têm sido freqüentemente usados como indicadores para ecossistemas perturbados e estressados (ANDERSON; DOMSCH, 1993).

\subsection{Terra Preta Antropogênica (TPA)}

A TPA se localiza na região da Amazônia ao longo dos rios, próximo das populações ribeirinhas (Figura 1). São encontrados nestes solos materiais arqueológicos como cerâmicas e artefatos líticos. Esses solos são de grande importância pela sua fertilidade e pelas altas concentrações de Ca, Mg, P e C (LEHMANN et al., 2003).

As áreas de localização da TPA são consideradas pequenas, variando de 2 a 3 hectares (SMITH, 1980), mas podem ser encontradas ocasionalmente em áreas maiores, numa extensão com mais de 100 ha.

Segundo informações do Museu Paraense Emílio Goeldi (www.museugoeldi.br/pesquisa/ecologia/tpa/paginas_imagens/tpaindex.htm) existem grandes quantidades 
de sítios arqueológicos conhecidos, mas se faz necessário um mapeamento do todos os locais de ocorrência de TPA na região Amazônica. Dados indicam que possam existir cerca de centenas de sítios espalhados pela região, podendo abranger cerca de $10 \%$ da bacia Amazônica.

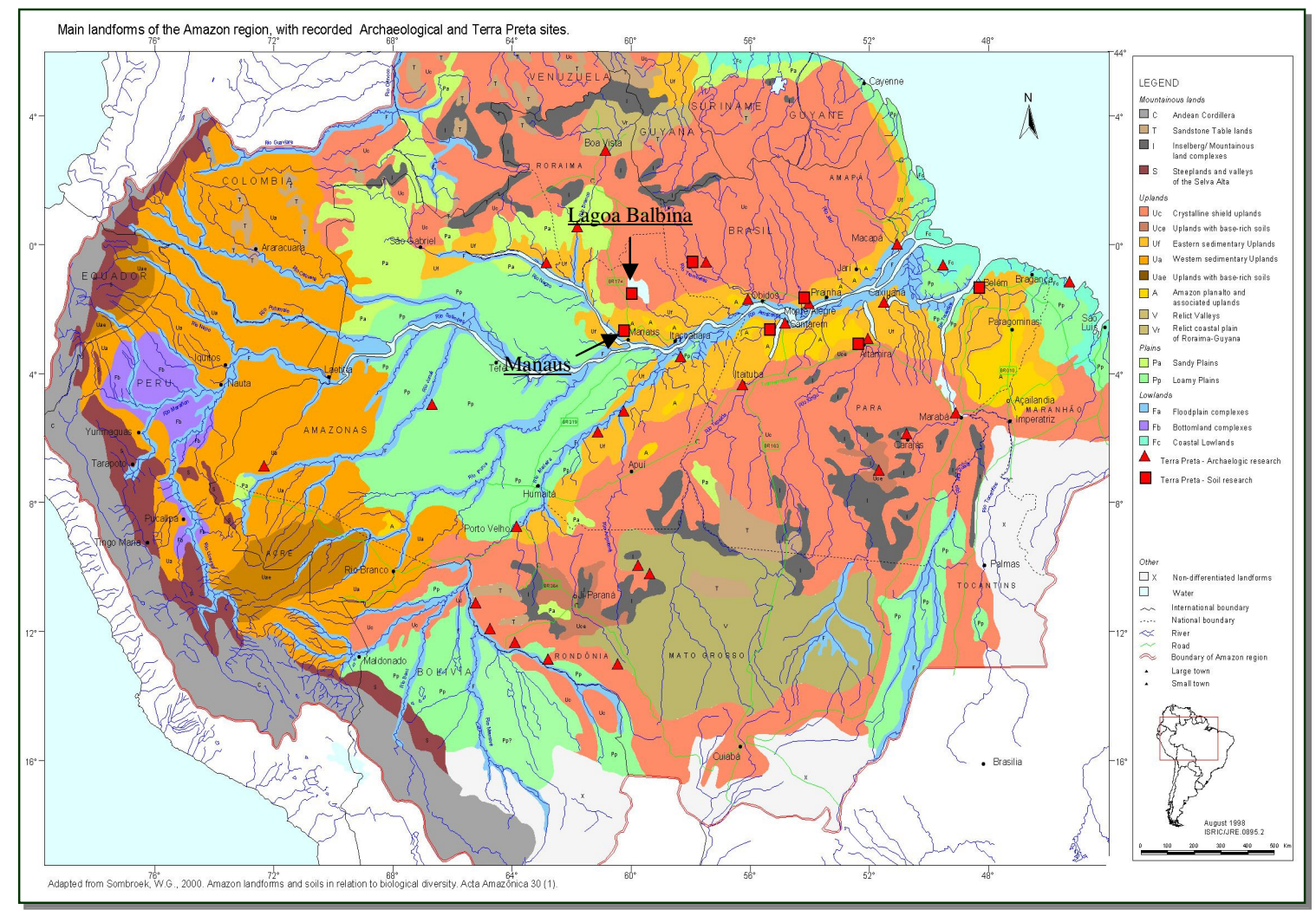

Figura 1. Mapa da localização de TPA na Amazônia. As áreas de TPA são consideradas pequenas, medem de 2 a 3 hectares. A camada de TPA, possui em média 40 a 60 $\mathrm{cm}$, mas pode atingir até $2 \mathrm{~m}$ de profundidade. Apesar da grande quantidade de sítios arqueológicos já conhecidos, não se tem um mapeamento de todas as ocorrências de TPA na Amazônia.

A presença dessa grande quantidade de material lítico e cerâmico pode ser responsável por essa deposição de minerais ao longo dos anos. A grande quantidade de matéria orgânica encontrada sugere que uma combustão incompleta desse material orgânico propiciou a alta fertilidade do solo (GLASER et al., 2001). A quantidade de material orgânico chega a ser 6 vezes mais estável que nos solos adjacentes sem horizonte A antropogênico (PABST, 1992; 
GLASER et al., 2001). A presença desses materiais arqueológicos e a sua coloração escura possibilitam a identificação e delimitação do solo. O enriquecimento do solo com nutrientes foi possível pelo manejo não intencional de restos orgânicos e do fogo pelas populações précolombianas (SOMBROEK, 1966; KERN; KÄMPF, 1989) (Figura 2).

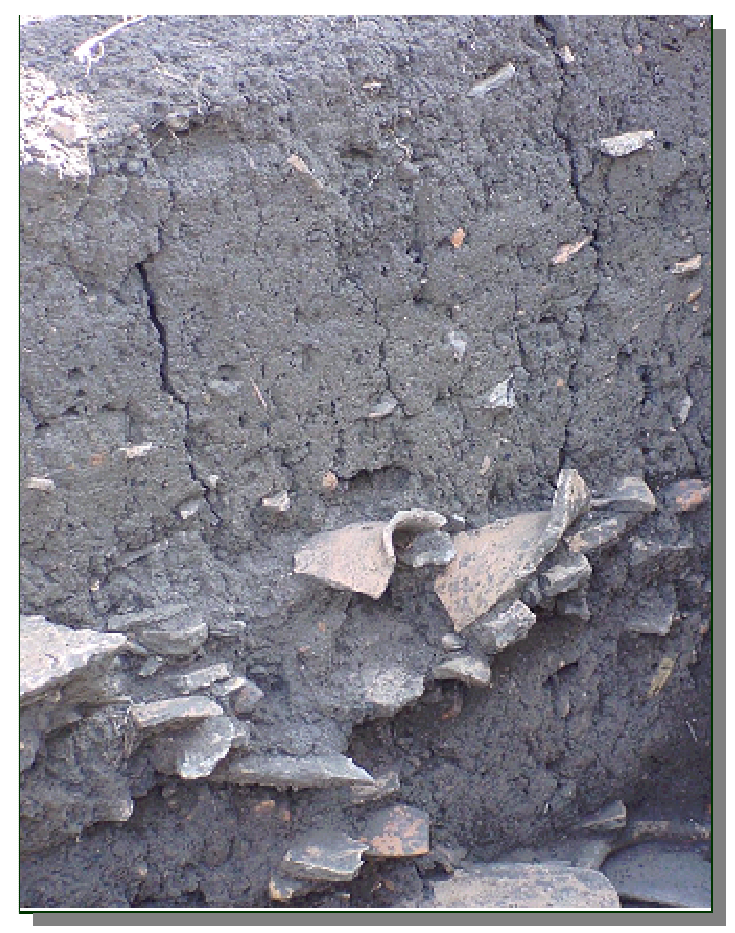

Figura 2. Presença de artefatos líticos em TPA (KERN; KAMPF, 1989).

As maiores diferenças existentes entre a Terra Preta e os solos adjacentes são a alta fertilidade, sem necessidade de adição de insumos ou com a utilização de uma quantidade bem menor de fertilizantes para agricultura de subsistência e alta atividade biológica. Essa característica justifica a importância em se estudar este tipo de solo, pois pode contribuir para a produção sustentável em solos tropicais de baixa fertilidade. As TPAs são encontradas sob os mais diferentes tipos de solos, como os latossolos, argissolos e terra roxa estruturada (SOMBROEK, 1966; SMITH, 1980). 
GARCIA (2006) identificou uma grande população de actinobactérias em TPA através do isolamento de amostras do solo e identificação da diversidade através da técnica ARDRA. Através desta técnica foi possível observar o polimorfismo de bactérias do mesmo gênero, mas não a espécie.

\subsection{Produção de Metabólitos Secundários}

Os microrganismos do solo representam um importante grupo para a produção de compostos biologicamente ativos. Esses compostos apresentam moléculas específicas com estruturas diversas e podem ser inibidores seletivos de algumas moléculas alvo (DONADIO et al., 2002). De acordo com esse mesmo autor, cerca de 17.000 antibióticos e outras moléculas bioativas têm sido produzidos por microrganismos procarióticos (WAWRIK et al., 2005).

Os metabólitos secundários são compostos especiais formados de estruturas diferentes com aplicações nas áreas farmacêutica, industrial e agricultura. Industrialmente importantes, os metabólitos secundários incluem rapamicina (imunossupressor), eritromicina (antibiótico), lovostatina (droga anticolesterolêmica) e epotilona B (droga anticancerígena), pigmentos, toxinas, indutores de competição ecológica e simbiose, pesticidas, inibidores de enzimas e promotores de crescimento de animais e plantas (ETCHEGARAY, 1998; WAWRIK et al., 2005).

Os metabólitos secundários são compostos produzidos pelos microrganismos e podem ser sintetizados pela via ribossomal e não-ribossomal (KOLTER; MORENO, 1992; KLEINKAUF; VON DÖHREN, 1996). Entre esses encontram-se os antibióticos, pigmentos, toxinas, indutores de competição ecológica e simbiose, pesticidas, inibidores de enzimas, 
agentes antitumorais, feromônios e promotores de crescimento de animais e plantas (DEMAIN, 1992). Esses compostos exibem uma atividade biológica potente e muitos desses têm sido usados nas áreas farmacológica e industrial (ANSARI et al., 2004).

Segundo DONADIO et al. (2002) os metabólitos secundários estão sendo obtidos após algumas décadas de extensivas pesquisas envolvendo provavelmente milhões de microrganismos. Esses compostos representam uma gama enorme de engenhosas estruturas e com potentes atividades biológicas. Entretanto, diferentes isolados geralmente produzem diferentes compostos. Assim, novos metabólitos bioativos continuam sendo identificados. A habilidade de produzir um grande número de metabólitos secundários quimicamente diferentes está mais associada com actinobactérias, mixobacteria, pseudomonades, cianobactérias e fungos filamentosos.

\subsection{Biossíntese de peptídeos não-ribossômicos}

Nos sistemas biológicos, duas estratégias diferentes são conhecidas para a catálise da formação da ligação peptídeo durante a biossíntese do peptídeo: a via ribossomal e o sistema de enzimas multifuncionais pela via não ribossomal.

A via ribossomal para a síntese de peptídeos depende dos códons do RNAm que se associam aos ribossomos, que consistem de RNAr e proteínas. O pareamento de bases dos códons no ribossomo resulta na captação de aminoácidos específicos aderidos a moléculas de RNAt e sua formação pelas ligações peptídicas (TORTORA et al., 2005). A primeira etapa na síntese de proteínas envolve a ativação da carboxila do aminoácido. Cada aminoácido possui uma enzima específica de ativação, a qual forma o complexo aminoaciladenilato-enzima e 
libera pirofosfato (PPi). Os dois sistemas via ribossomal e a multi-enzimática não-ribossomal são ativados $\operatorname{logo}$ em seguida. Essa relativa estabilidade intermediária é devido a (tio)esterificação sobre o RNAt ou um grupo prostético 4 '-fosfopantoteína da peptídeo sintetase. Através da via não ribossomal os peptídeos são sintetizados por enzimas capazes de produzir peptídeos biologicamente ativos a partir de substratos, em muitos casos nãoprotéicos, chamadas de peptídeo sintetase não ribossômica e policetídeo sintase (KLEINKAUF; VON DÖHREN, 1996). O sistema de enzimas multifuncionais por via não ribossomal para a síntese de peptídeos freqüentemente contém aminoácidos não usuais, incluindo aminoácidos não protéicos ou modificados, sem a participação direta do ácido nucléico A Figura 3 apresenta um esquema de biossíntese de peptídeos (STACHELHAUSS et. al., 1996). É conhecido um grande número de diferentes tipos estruturais de peptídeos, os quais por sua composição, não poderiam ser sintetizados a partir da via ribossomal que está restrita a 20 resíduos de aminoácidos (KLEINKAUF; VON DÖHREN, 1996).

A formação de peptídeos não ribossômicos está diretamente ligada ao módulo que corresponde ao segmento de DNA que codifica o sistema multienzimático responsável pela adição de um amino ou hidroxiácido, juntamente com alguma atividade catalítica. A seqüência de eventos é determinada por um arranjo espacial de domínios catalíticos sendo comandadas a nível gênico pelos módulos. O segmento protéico seria denominado de unidade de sintetase. Os fragmentos protéicos obtidos por proteólise são denominados domínios, que por sua vez são formados por subdomínios onde apresentam uma estrutura similarmente definida (KLEINKAUF; VON DÖHREN, 1996; ETCHEGARAY, 1998). A biossíntese de peptídeos não-ribossômicos pode ocorrer também pelo mecanismo não-arranjo de tióis. Diferente do mecanismo de arranjo de tióis, o não-arranjo de tióis não inclui ligação enzimática, covalentemente ligada. 


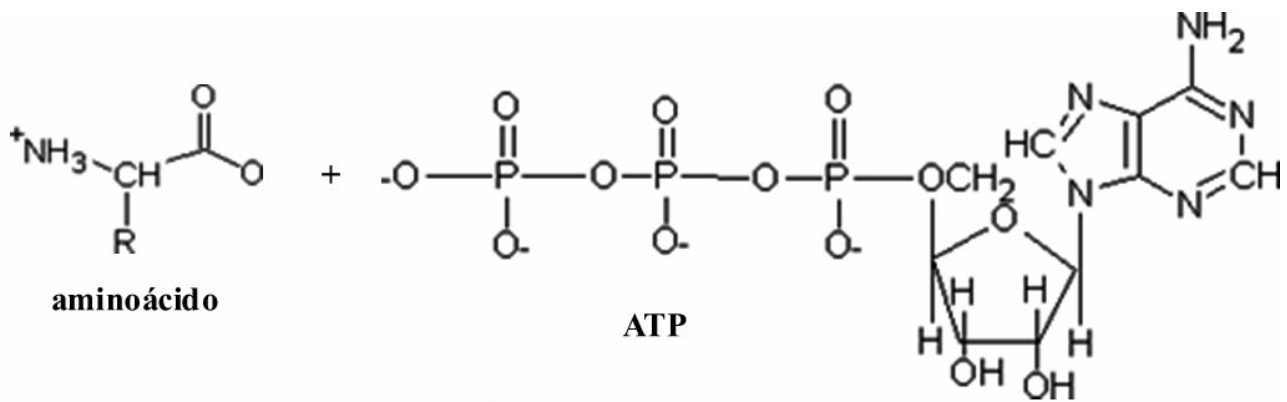

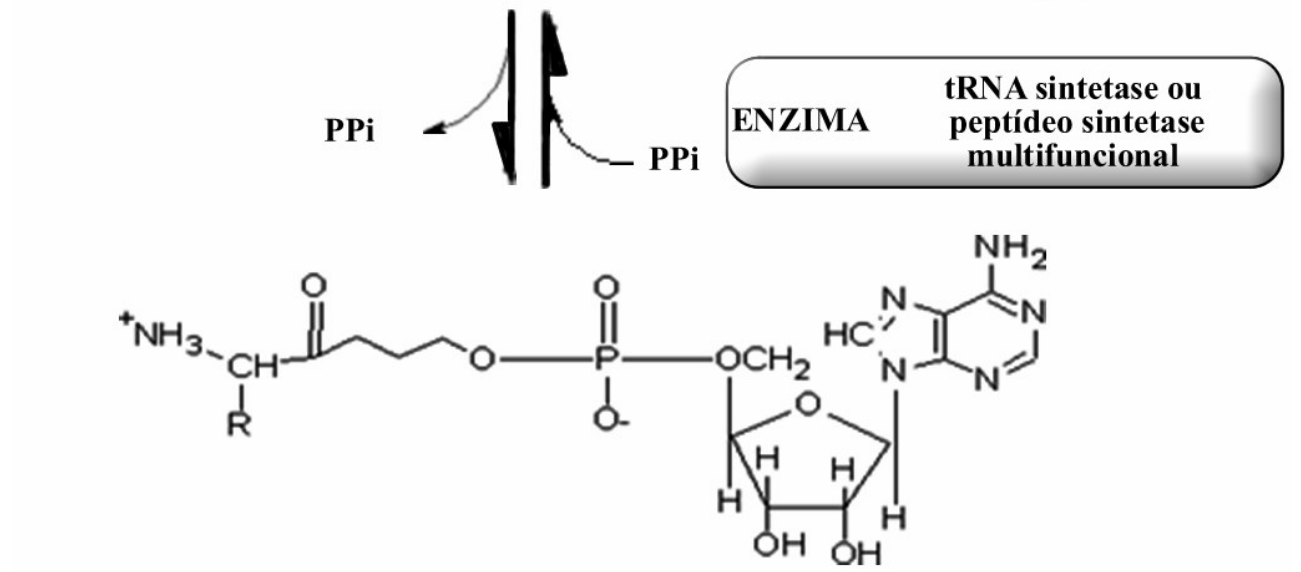

amino aciladenilato (enzima associada)

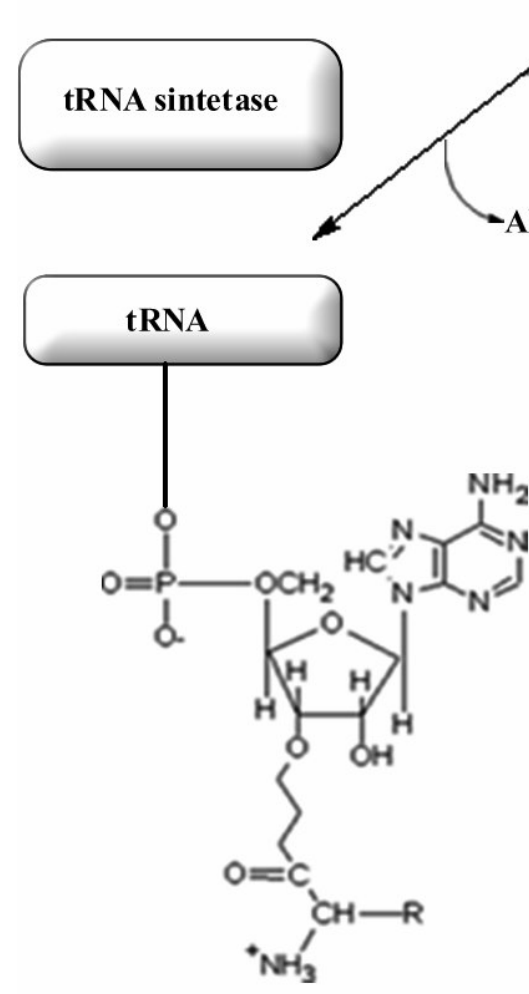

aminoacil-tRNA

VIA RIBOSSOMAL

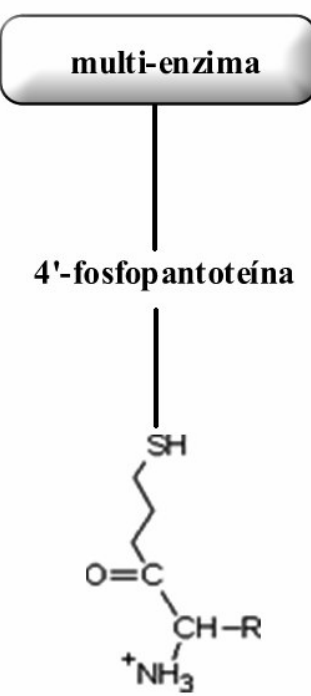

ligação aminoácido tioéster

VIA NÃO RIBOSSOMAL

Figura 3. Ativação de aminoácidos na síntese peptídica pela via ribossomal e não-ribossomal. 
O modo de síntese pelas enzimas multifuncionais emprega o mecanismo de múltiplo carreador de tióis e possui também uma diversidade elevada na especificidade e tamanho do substrato. Suas massas moleculares variam de $123 \mathrm{KDa}$, como por exemplo, para a gramicidina $\mathrm{S}$ sintetase (GrsA) a $1689 \mathrm{KDa}$ para a ciclosporina sintetase (SimA) (STACHELHAUSS et al., 1996).

As PKSs modulares são proteínas multifuncionais e são classificadas em tipo I (modulares) e tipo II (iterativas). Cada classe de PKS se assemelha as da classe das ácidos graxos sintases (FAS): PKS do tipo I possui um multidomínio estrutural semelhante a do tipo FAS tipo I de fungo e animais e PKS do tipo II carrega em cada sítio catalítico uma proteína separada, característica das FAS tipo II encontrada em bactérias e plantas (JENKEKODAMA et al., 2005)

As moléculas sintetizadas pelas NRPSs normalmente são cíclicas e têm uma grande quantidade de aminoácidos não proteinogênicos e freqüentemente contém aminoácidos conectados por ligações diferentes das peptídicas, tais como as ligações sulfídicas. No caso das NRPSs, um aminoácido é incorporado ao peptídeo por um módulo, assim produtos contendo 10 aminoácidos são construídos por uma NRPS de 10 módulos juntos (CHALLIS; NAISMITH, 2004).

As análises genéticas e bioquímicas de muitas NRPSs revelaram que estas proteínas exibem uma estrutura modular em que um módulo é definido como a unidade mínima, independente que catalisa todas as reações necessárias para modificar e incorporar um aminoácido específico na cadeia crescente do peptídeo. $\mathrm{O}$ arranjo genético dos genes que codificam estes módulos é geralmente colinear com a seqüência do aminoácido do produto do 
peptídeo. Há mais de trinta anos, um modelo foi proposto para a síntese de peptídeos em que cada módulo é carregado com um aminoácido específico (LIPMANN, 1971).

Actinomicetos, bacilos e fungos são comumente associados à metabólitos secundários não-ribossômicos e sua biossíntese é bem estudada. No passado, estes organismos foram de grande interesse devido à produção de antibióticos não-ribossômicos, tais como gramicidina $S$ e ciclosporina (imunossupressora) produzidos pelo fungo Tolypocladium niveum (KLEINKAUF; VON DÖHREN, 1990). A peptídeo sintetase descoberta em Actinomyces inclui aquelas envolvidas na biossíntese dos antibióticos ansatrienina (CHEN et al., 1999) e os do grupo vancomicina, cloroeremomicina (VAN WAGENINGEN et al., 1998), bleomicina (DU; SHEN, 1999) e estreptomicina (FERNANDEZ-MORENO et al., 1997). O biossurfactante fengicina, que exibe atividade antimicrobiana e antiviral, é produzido via um mecanismo de arranjo de tióis em Bacillus subtilis (STELLER et al., 1999). Biossíntese nãoribossômica de agentes antifúngicos micosubtilina tem sido estudada nestas espécies de Bacillus (DUITMAN et al., 1999). Pseudomonas sp produz um sideróforo que consiste no fator de virulência, pioquelina (QUADRI et al., 1999) e a fitotoxina siringomicina (ZHANG et al., 1995) via um mecanismo de arranjo de tióis. O gene responsável pela biossíntese do fator de virulência yersiniabactina e micobactina de Yersinia pestis e Mycobacterium tuberculosis, respectivamente, tem sido completamente seqüenciado e a via biossintética foi proposta (GEHRING et al., 1998). A via não-ribossômica tem sido implicada na biossíntese do biossurfactante serrawetina, de Serratia liquefaciens (LINDUM et al., 1998). Peptídeos não-ribossômicos são também identificados em Myxobacteria, incluindo o inibidor de transporte de elétrons myxothiazol produzido por Stigmatella aurantiaca (SILAKOWSKI et al., 1999) e antibiótico TA de Myxococcus xanthus (PAITAN et al., 1999). A quelação do ferro pelas bactérias é vital para sua sobrevivência e é freqüentemente uma determinante da 
virulência nos patógenos. As NRPSs sintetizam sideróforos, como por exemplo a enterobactina, a qual tem uma elevada afinidade por ferro (GEHRING et al., 1998).

\subsection{Sideróforos}

Os sideróforos (do Grego: “carreadores de ferro") são metabólitos secundários produzidos pela biossíntese das NRPS e PKS. São quelantes com massa molecular entre 400 e 2000 Da. Sua função é de se ligar ao Fe(III), em condições de baixo ferro livre (NEILANDS, 1995). Podem ser produzidos por espécies aeróbicas e facultativamente por espécies anaeróbicas. $\mathrm{Na}$ variedade de microrganismos conhecidos que sintetizam sideróforos estão incluídas várias bactérias entéricas; bactérias patogênicas de humanos, animais, fungos e de plantas; microrganismos do solo; espécies Gram-positivas e negativas; cianobactérias e algas superiores; bactérias fixadoras de nitrogênio; alguns tipos de leveduras (BENITE et al., 2002) e até certas espécies de plantas (fitosideróforos).

Os microrganismos aeróbicos precisam do ferro para realizar várias funções como a redução do oxigênio para a síntese de ATP, redução de precursores de DNA, formação do grupo heme e para outras finalidades. É necessário em torno de um micromolar de ferro para um crescimento bacteriano ótimo (NEILANDS, 1995).

A disponibilidade do ferro para as raízes das plantas depende de quelantes orgânicos que manteriam um adequado suprimento de ferro por difusão e fluxo de massa em concentrações tão baixas como $10^{-8}$ M (HOWELL, 1980). O ferro é indispensável para a planta, pois faz parte da enzima nitrogenase, responsável pela conversão do nitrogênio em amônia, da leghemoglobina, que tem a função do controle da quantidade de oxigênio dentro dos nódulos 
contaminados pela bactéria e dos citocromos que são catalisadores de elétrons no processo da respiração celular do bacterióide (LUCA et al., 1988). Como estratégia para a obtenção do ferro, as bactérias produzem metabólitos secundários que conseguem se ligar ao $\mathrm{Fe}$ e transportá-lo para dentro da célula (PATRIARCA et al., 2002). Esse processo acontece com algumas bactérias que se relacionam simbioticamente com as plantas. Um exemplo dessa simbiose são as bactérias do gênero Rhizobium sp. As bactérias Rhizobium entram nos pêlos radiculares de plantas leguminosas quando ainda estão no estágio de plântulas formando os nódulos. Para converter o nitrogênio em amônia a bactéria precisa de uma enzima chamada nitrogenase, que depende do ferro para a sua formação. A depleção do ferro no solo faz com que a bactéria produza metabólitos secundários responsáveis pela sua quelação, disponibilizando o ferro para a bactéria e também para a planta (NEILANDS, 1995; HOWELL, 1980; LUCA et al., 1988). Esse processo facilita a promoção direta de crescimento da planta através da produção de sideróforos.

A função do sideróforo envolve o transporte de ferro através da membrana celular bacteriana. A entrada do ferro no citoplasma somente acontece depois que o ferro é reduzido e/ou desmembrado de seu ligante. Em alguns casos o sideróforo é reciclado para iniciar novamente o processo de absorção do ferro (NEILANDS, 1995).

Os sideróforos possuem pelo menos um ácido hidroxâmico, um catecol e/ou um ácido a-hidroxicarboxílico como sítios ligantes (Figura 4). Uma característica comum destes sítios é a formação de anéis quelatos de cinco membros muito estáveis com o Fe(III). Os sideróforos podem apresentar afinidade por outros ligantes formando complexos relativamente estáveis com o cobre (II), gálio(III), molibdênio(II), alumínio(III) entre outros. 

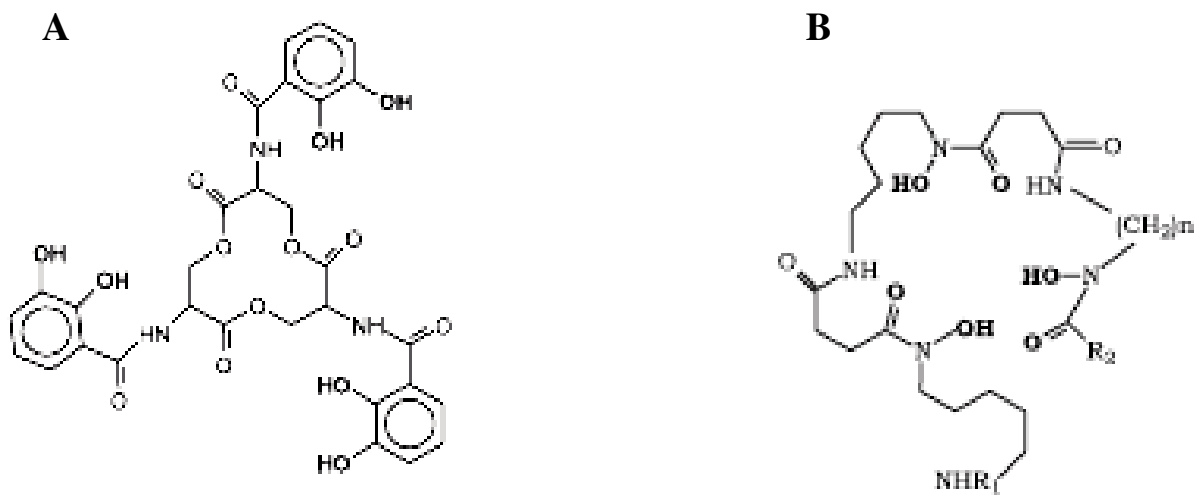

Figura 4. Classes dos sideróforos: A) enterobactina (catecol); B) desferrioxamina
(hidroxamato).

Para que ocorra a disponibilização do ferro para a bactéria são necessários vários processos químicos para a solubilização e captação do ferro mediado pelo sideróforo: 1) quelação seletiva do ferro; 2) reconhecimento molecular do complexo sideróforo-Fe(III); 3) transporte do Fe complexado através da membrana celular; 4) deposição do Fe, dentro de um sítio apropriado na célula (superfície ou interior celular), sendo que neste último a troca do ligante pode ou não ser seguida pela redução de $\mathrm{Fe}(\mathrm{III})$ e/ou pela hidrólise do ligante (BENITE et al., 2002).

O que facilita essa ligação altamente estável com o íon Fe(III) é a sua dureza, o tamanho, sua configuração de elétrons d, a alta densidade de carga e a alta eletronegatividade (BENITE et al., 2002).

O primeiro trabalho que relata a expressão molecular do sideróforo é com a Salmonella typhimurium (ERNST et al., 1978). Através de mutagêneses químicas foi identificado um gene designado fur (ferric upptake regulation), o qual controla a expressão do sideróforo. 
Segundo NEILANDS (1981), algumas bactérias Gram-negativas possuem uma via de absorção de ferro altamente específica envolvendo dois componentes principais. Um dos componentes é a produção de ligantes denominados sideróforos. O outro componente é um sistema de transporte ativo envolvendo um complexo de proteínas de membrana que reconhecem o complexo ferro-sideróforo e realizam o transporte. Segundo POLE et al. (1990) e RABSCH et al. (1999) algumas dessas proteínas transportam complexos ferro-sideróforos produzidos pela própria bactéria, enquanto outros transportam complexos produzidos por outros microrganismos.

Bactérias Gram-negativas têm desenvolvido um especial sistema transportador de membrana externo que consiste em receptores externos de membrana e um complexo de membrana citoplasmático formado pelas proteínas $E x b \mathrm{~B}, E x b \mathrm{D}$ e TonB. O sistema TonB se baseia na força próton motora da membrana citoplasmática com alta afinidade com receptores externos, o qual são conhecidos como receptores TonB dependentes. Algumas bactérias possuem uma grande disposição para receptores TonB dependentes diferentes, sendo cada um com sua própria especificidade, a fim de utilizar os sideróforos (sideróforos heterólogos) dos seus vizinhos carregados com o ferro. A bactéria Pseudomonas aeruginosa um patógeno oportunista humano, por exemplo, possui os receptores para seus próprios sideróforos pioverdina e piochelina, mas possui a habilidade de produzir outros 32 receptores TonBdependentes. Estes receptores adicionais são usados para captar enterobactina produzida por diferentes Enterobacteriaceae (DEAN; POOLE, 1993; GHYSELS et al., 2005) e a ferrioxamina ou o ferricromo produzidos por diversas bactérias e fungos, respectivamente (LLAMAS et al., 2006). 
Vários sideróforos produzidos por Pseudomonades apresentam utilidades em processos de biorremediação, sendo um deles a fitorremediação, onde solos contaminados por metais pesados como $\mathrm{Cr}$, $\mathrm{Hg}$ e $\mathrm{Pb}$ seriam limpos através da quelação pelos sideróforos (BRAUD et al., 2006).

Alguns metais, chamados de fitotóxicos, causam inibição do crescimento e posterior morte da planta. Um isolado bacteriano extraído de uma região da Índia, denominado KNP9 produziu sideróforo com uma função de promotor de crescimento em plantas "Panki power". A concentração de chumbo e cádmio na raiz e no broto foi reduzida na presença do isolado de 37,5 para 93,19\%. Análise por $16 \mathrm{~S}$ ribossomal identificou o isolado como $P$. putida (TRIPATHI et al., 2005).

A família Pseudomonadaceae são bactérias GRAM-negativas, bastonetes, estritamente aeróbicas e oxidase positiva. Possuem motilidade por flagelos. São bactérias que respiram e são capazes de utilizar componentes do carbono orgânico como fonte de energia e carbono. Apresentam pigmentação amarela, vermelha, laranja, rosa, e violeta. Podem ser encontradas nos solos e águas e estão sendo relacionadas com a produção de sideróforos. Algumas promovem degradação em ovos, carnes e seus produtos. Podem ser patogênicas ao homem causando doenças de pele, úlcera de córnea, otites, pneumonia, sepsis, endocardites e infecções no trato urinário (CULLIMORE, 2000).

Pseudomonas fluorescens 2P24 é um agente de biocontrole isolado de solos produtores de trigo da China. Esse isolado produziu componentes antifúngicos, cianido de hidrogênio e sideróforos. Esse isolado utiliza um sistema de sinais chamado de "quorum-sensing" que regula a atividade de biocontrole através da produção de sideróforos. Foi identificado no 
isolado 2P24 um sistema de "quorum-sensing" formado por PcorR e PcoI da família LuxRLuxI. A deleção do PcoI do isolado 2P24 aboliu a produção dos sinais do "quorum-sensing", mas não foi detectado efeito na produção dos metabólitos antifúngicos. Porém, essa mutação mostrou um significativo efeito na formação de biofilmes, colonização na rizosfera do trigo e habilidade no biocontrole contra doença "take-all” do trigo (WEI e ZHANG, 2006).

Um estudo sobre os mecanismos pelos quais a expressão gênica controla a absorção de ferro, envolvendo o metabolismo de pioverdina em $P$. aeruginosa mostrou que a transcrição desses genes foi reprimida pela presença de ferro no meio de crescimento. Três promotores desses genes foram clonados e a atividade desses promotores mostrou-se dependente da quantidade de ferro no meio de cultura (ROMBEL et al., 1995).

Mutações em P. flurescens WCS374, com deficiência na biossíntese do sideróforo fluorescente pseudobactina, ainda exibe atividade de sideróforo, indicando a produção de um segundo sideróforo (MERCADO-BLANCO et al., 2001). Uma recombinação de um clone (pMB374-07) com um gene da biblioteca WCS374 que possui loci necessário para o biossíntese de ácido salicílico e para um segundo sideróforo pseudomonina foi isolado. Essa região responsável pela biossíntese de ácido salicílico e de pseudomonina foram transferidas para uma $P$. putida com deficiência na produção de pseudobactina. Produtos de ORF (open reading frames) (pmsE) codificou uma proteína com forte semelhança com enzimas envolvidas no biossíntese de sideróforos em outras espécies bacterianas. Várias evidências indicam que a biossíntese de ácido salicílico e de pseudomonina estão relacionados (MERCADO-BLANCO et al., 2001). Além disso, esses autores isolaram um mutante Tn5 (374-05), o qual não produziu ácido salicílico e pseudomonina. 
Através de uma completa análise genômica de Agrobacterium tumefaciens C58, foi identificado um gene que codifica a biossíntese de um metabólito com atividade de sideróforo. O suporte para esta conclusão veio de análise genética e regulatória do cluster, junto com a purificação de um metabólito de A. tumefaciens C58 com atividade férrica (RONDON et al., 2004).

No Brasil, poucos trabalhos foram realizados foram realizados até o presente com o foco na prospecção de genes da biodiversidade microbiana. Os estudos se concentraram na interação do microrganismo com a planta hospedeira e de produção de sideróforos, como no caso das leguminosas com Rhizobium (SACCOL DE SÁ, 2001) e Bradyrhizobium, assim como, mais recentemente, com a bactéria Xylella fastidiosa que ataca citros. De acordo com os dados obtidos no seqüenciamento desta bactéria, foi encontrado a presença de ORFs associadas com proteínas com afinidade por ferro. Em meio de cultivo sem a presença do ferro, esta bactéria produziu receptores de sideróforos caracterizados molecularmente (PACHECO et al., 2005) e bioquimicamente (SILVA-STENICO et al., 2005).

Os genomas dos patógenos de plantas Xanthomonas axonopodis (Xac) e X. campestris (Xcc) foram analisados e investigados quanto à presença de peptídeos não ribossômicos. Essas análises revelaram que as duas linhagens possuem genes relacionados com a biossíntese de policetídeos e poliaminas, os quais poderiam estar envolvidos na formação de substratos para a biossíntese de sideróforos (ETCHEGARAY et al., 2004).

A Tabela 1 apresenta alguns sideróforos e os microrganismos responsáveis por sua produção. 
Tabela 1- Sideróforos produzidos por bactérias e fungos.

\begin{tabular}{|c|c|c|c|}
\hline Sideróforo & Microrganismo & $\begin{array}{c}\text { Massa } \\
\text { Molecular } \\
\text { (Da) }\end{array}$ & Referência \\
\hline Aminochelina & Azotobacter vinelandii & 224 & $\begin{array}{l}\text { PAGE e } \\
\text { VONTIGERSTROM (1988) }\end{array}$ \\
\hline Piochelina & Pseudomonas aeruginosa & 324 & COX et al. (1981) \\
\hline Pseudomonina & Pseudomonas fluorescens & 330 & ANTHONI et al. (1995) \\
\hline Chrisobactina & Erwinia chrysanthemi & 369 & PERSMARK et al. (1989) \\
\hline Rizobactina & Rhizobium meliloti & 377 & SMITH et al. (1985) \\
\hline Desferrioxiamina & Streptomyces pilosus & 561 & BICKEL et al. (1960) \\
\hline Agrobactina & Agrobacterium tumefaciens & 636 & NEILANDS (1983) \\
\hline Vibriobactina & Vibrio cholerae & 706 & GRIFFITHS et al. (1984) \\
\hline Coprogênio & Penicillium sp. & 822 & OHRA et al. (1995) \\
\hline Coprogênio B & Neurospora sp. & 822 & DIEKMANN (1970) \\
\hline Pseudobactina & $\begin{array}{l}\text { Pseudomonas } \\
\text { fluorescensputida }\end{array}$ & 1042 & TEINTZE et al. (1981) \\
\hline Pioverdina I & Pseudomonas fluorescens & 1315 & POPPE et al. (1987) \\
\hline
\end{tabular}

\subsection{Compostos antimicrobianos}

Antibióticos podem ser definidos como substâncias produzidas por um organismo que apresenta efeitos adversos em outros organismos (DAVIES, 1990). Esta definição, porém, não reflete o papel dos antibióticos nos ambientes naturais, os quais são pouco entendidos, embora pelo menos algumas destas substâncias conferiram vantagem competitiva para o microrganismo produtor (MARTIN; DEMAIN, 1980). A capacidade das bactérias em produzir substâncias antibióticas é bem conhecida. 
Muitos dos compostos classificados como antibióticos são peptídeos ou pequenas proteínas (KOLTER; MORENO, 1992). Estes freqüentemente contem resíduos de aminoácidos não comumente encontrados em proteínas, levantando a questão de como estes peptídeos podem ser elaborados. Muitos estudos mostram que essas biomoléculas de estrutura peptídica podem ser sintetizadas pela via não ribossomal através de uma séria de reações catalizadas pelas enzimas NRPS e PKS (KLEINKAUF; VON DÖHREN, 1996; MARAHIEL, 1992; STACHELHAUSS; MARAHIEL, 1995). Essas enzimas sintetizam moléculas lineares e circulares, tais como gramicidina, polimixina e bacitracina (KLEINKAUF; VON DÖHREN, 1987). Nisina (BUCHMAN et al., 1988), subtilina (BANERJEE; HANSEN, 1988) e microcina B17 (DAVAGNINO et al., 1986) são exemplos de peptídeos antibióticos, os quais ocorrem pela via ribossomal.

Um organismo que produz um peptídeo antibiótico precisa ser capaz de: a) sintetizar o antibiótico; b) exportar o antibiótico extracelularmente; c) proteger-se da ação do antibiótico (KOLTER; MORENO, 1992). A síntese do antibiótico envolve vários passos: transcrição, tradução, modificação pós-tradução de resíduos de aminoácidos e processamento pela clivagem da seqüência principal do N-terminal.

Há muitos relatos de que o solo é rico em microrganismos capazes de sintetizarem antibióticos, mas a freqüência com que a síntese ocorre em níveis ecologicamente significativos na natureza não é muito explorada. Usando-se técnicas genéticas e moleculares, acopladas com análises sensíveis e bons equipamentos, demonstrou-se que os microrganismos sintetizam uma variedade dos antibióticos, condições inferiores às encontradas no ambiente, como por exemplo, na rizosfera (parcela do solo enriquecida em carbono e energia liberados pelas raízes da planta). Estes antibióticos podem contribuir para a competitividade microbiana 
e à supressão dos patógenos da raiz da planta. Assim, as bactérias que os produzem são conseqüentemente de considerável interesse para fins práticos para o controle de doença de planta (THOMASHOW et al., 1990). Geralmente, as técnicas usadas para compreender o papel dos antibióticos na rizosfera são aplicáveis a outros ambientes onde os mecanismos dos microrganismos antagonistas ou da produção de metabólitos bioativos são de interesse. Quando as técnicas bioanalíticas e moleculares são utilizadas em conjunto, as mesmas permitem a detecção e a quantificação dos metabólitos produzidos, como também uma avaliação de sua atividade, e daí sua importância ecológica.

Acredita-se que novos antibióticos e outros metabólitos secundários bioativos podem ainda ser descobertos de fontes microbianas. A probabilidade de se encontrar novos compostos bioativos depende de alguns fatores críticos. Por um lado, existe o número de linhagens selecionadas e seus níveis de diversidade; do outro, essas linhagens são únicas e seu potencial para produzir metabólitos secundários é grande (DONADIO et al., 2002). Estes dois fatores são extremamente importantes, já que em uma seleção intensiva de microrganismos é menos provável de se encontrar novos metabólitos do que em grupos inexplorados. 


\section{MATERIAL E MÉTODOS}

\section{1 Área de Estudo: Localização das coletas}

As áreas de estudos estão localizadas no município de Rio Preto da Eva e de Presidente Figueiredo - AM (Figura 5), a 165 km de Manaus, próxima à Comunidade Rumo Certo e às margens da lagoa da Hidroelétrica Balbina.

$\mathrm{O}$ clima na região é quente e úmido com temperatura média entre $25^{\circ} \mathrm{C}$ e $35^{\circ} \mathrm{C}$. A vegetação é formada pela floresta tropical e há grande predominância de terras acidentadas e o solo apresenta características arenosas nas áreas mais altas e argila nas áreas mais baixas. A área de TPA é classificada como Latossolo Amarelo Antrópico, o solo de várzea é classificado como Gleissolo e o solo adjacente, localizado entre as áreas de TPA e várzea, é classificada como Latossolo Amarelo.

Amostras coletadas em Rio Preto da Eva são provenientes de solos cultivados, cuja exploração tem sido para fins agrícolas, enquanto que as obtidas no sítio Terra Preta (Hidroelétrica Balbina) são de solos não cultivados, na comunidade Rumo Certo, nas proximidades da Hidrelétrica Balbina. Foram coletadas amostras dos solos de Terra Preta Antropogênica $\left(01^{0} 30^{\prime} 26,4^{\prime \prime} \mathrm{S}-60^{0} 05^{\prime} 34,0^{\prime} \mathrm{W}\right)$ e de solos adjacentes $\left(01^{0} 30^{\prime} 27,0^{\prime \prime} \mathrm{S}-60^{0}\right.$ 05' 33” W). 


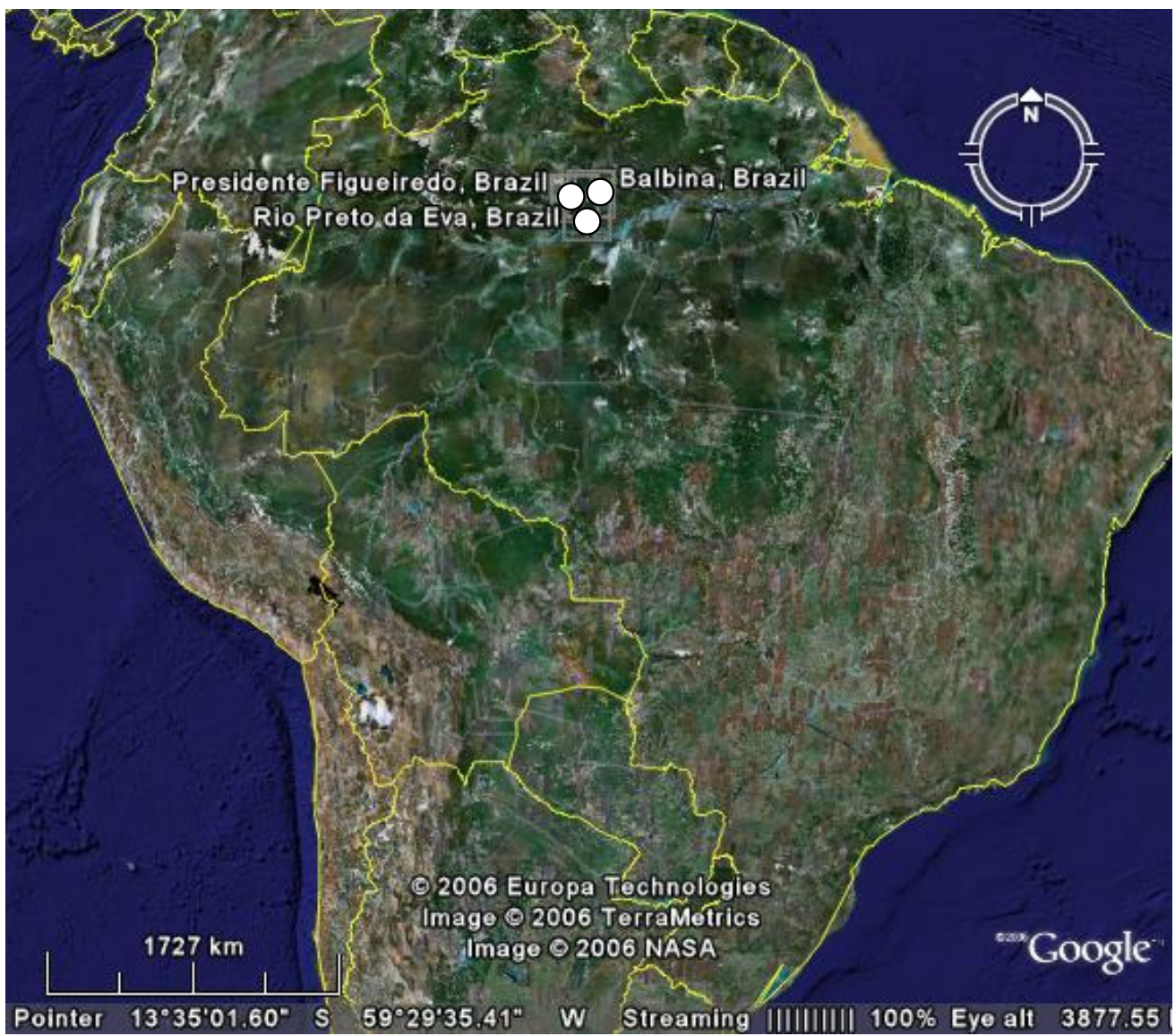

Figura 5. Imagem aérea da localização dos solos de Terra Preta e adjacente obtida através do programa GoogolEarth 4.0.2091 (beta).

\subsection{Amostragem}

Foram coletadas amostras de solo em cinco pontos (em TPA e solo adjacente à TPA), com profundidades de 15,30 e $45 \mathrm{~cm}$ para Sítio Terra Preta e 10 e $20 \mathrm{~cm}$ para adjacente (Figura 6). Após a coleta as amostras foram acondicionadas, armazenadas sob baixa temperatura $\left(-4^{\circ} \mathrm{C}\right)$ e enviadas imediatamente para o laboratório de Biologia Celular e Molecular do Centro de Energia Nuclear na Agricultura da Universidade de São Paulo em Piracicaba, SP. 
A

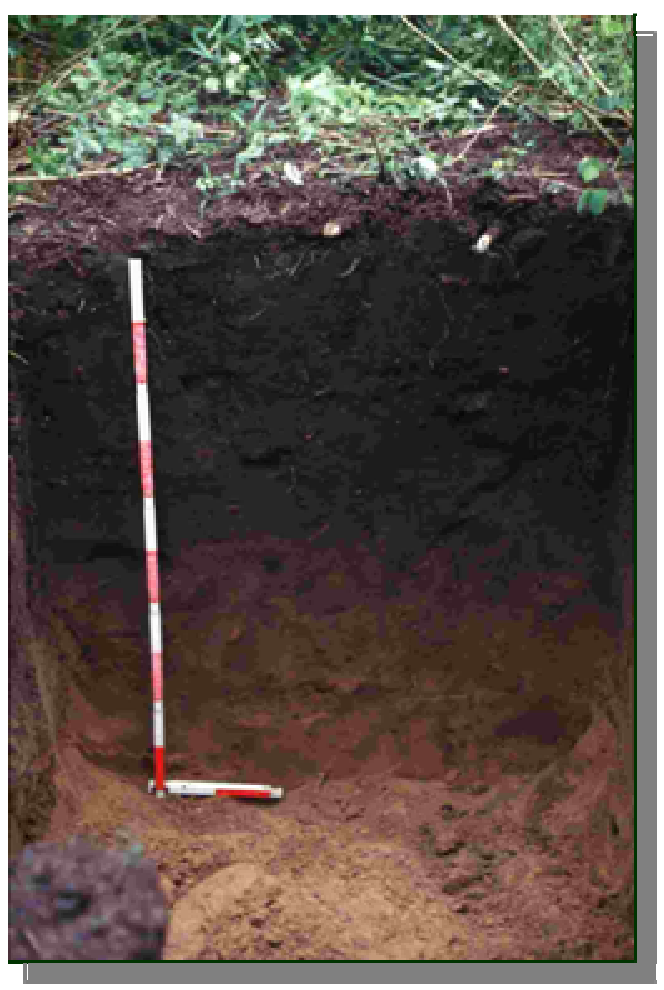

B

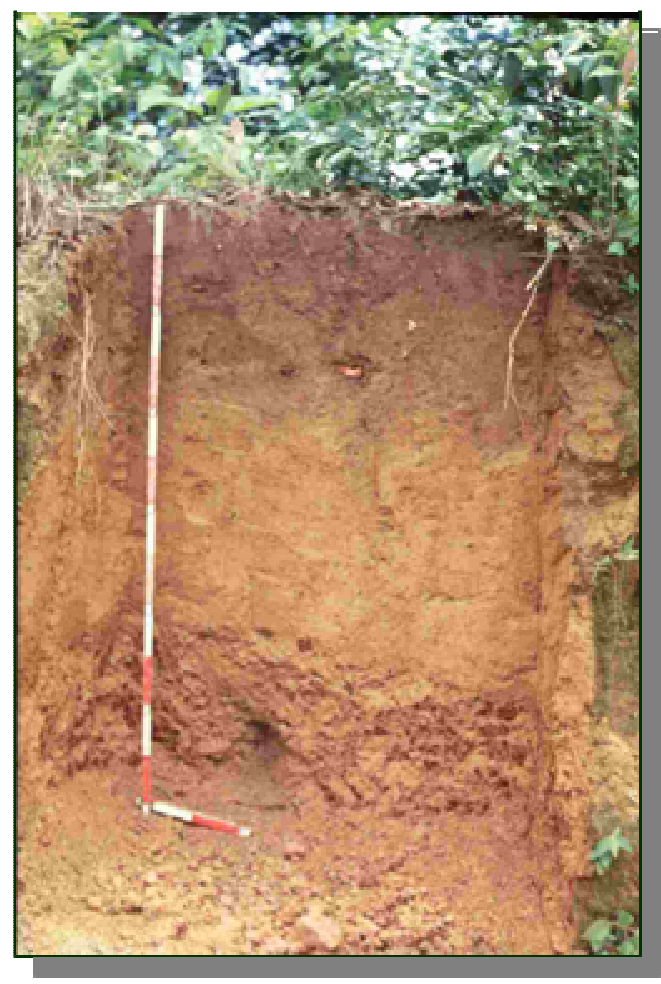

Figura 6. Áreas de coleta de solos de TPA (A) e solo adjacente (B).

\subsection{Isolamento das linhagens}

Os isolados dos solos de TPA foram isolados pela aluna de mestrado Fabiana Cannavan e depositadas na coleção de culturas do Laboratório de Biologia Celular e Molecular - CENA. A cianobactéria Fischerella sp CENA 19 foi utilizada como controle nos testes moleculares de NRPS e PKS (ETCHEGARAY et al., 2004). As bactérias testes Salmonella typhimurium e Bacillus subtilis e os fungos testes Sclerotium rolfsii e Rhizoctonia solani usados nos bioensaios foram cedidos pelo Dr. Itamar Soares de Melo (Embrapa Meio Ambiente, Jaguariúna). Os demais microrganismos testes foram obtidos da coleção de cultura do Laboratório de Biologia Celular e Molecular - CENA/USP. 
Os isolados da Terra Preta foram mantidos em meio Actinomycete Isolation Agar (Difco 212168) contendo: caseinato de sódio $2,0 \mathrm{~g} / \mathrm{L}$; asparagina $0,1 \mathrm{~g} / \mathrm{L}$; propionato de sódio 4,0 $\mathrm{g} / \mathrm{L} ; \mathrm{K}_{2} \mathrm{HPO}_{4}$ 0,5 g/L; $\mathrm{MgSO}_{4} 7 \mathrm{H}_{2} \mathrm{O} 0,1 \mathrm{~g} / \mathrm{L} ; \mathrm{FeSO}_{4} 7 \mathrm{H}_{2} \mathrm{O}$ 0,001g/L; glicerol 5,0 g/L; Agar $15,0 \mathrm{~g} / \mathrm{L}$. Todos os isolados foram preservados em glicerol $50 \%$ a $-80^{\circ} \mathrm{C}$.

A Tabela 2 descreve todos os isolados usados neste trabalho.

Tabela 2- Isolados de bactérias e localização.

\begin{tabular}{|c|c|c|c|}
\hline Numeração & Isolado & Localização & Profundidade $(\mathrm{cm})$ \\
\hline 1 & TP01 & Adjacente & $0-10$ \\
\hline 2 & TP02 & Terra Preta & $0-18$ \\
\hline 3 & TP03 & Adjacente & $10-20$ \\
\hline 4 & TP04 & Adjacente & $10-20$ \\
\hline 5 & TP05 & Adjacente & $10-20$ \\
\hline 6 & TP06 & Adjacente & $10-20$ \\
\hline 7 & ТP07 & Adjacente & $10-20$ \\
\hline 8 & TP08 & Adjacente & $10-20$ \\
\hline 9 & TP09 & Adjacente & $10-20$ \\
\hline 10 & TP10 & Adjacente & $10-20$ \\
\hline 11 & TP11 & Adjacente & $10-20$ \\
\hline 12 & TP12 & Adjacente & $10-20$ \\
\hline 13 & TP13 & Adjacente & $10-20$ \\
\hline 14 & TP14 & Adjacente & $0-10$ \\
\hline 15 & TP15 & Adjacente & $0-10$ \\
\hline 16 & TP16 & Adjacente & $0-10$ \\
\hline 17 & TP17 & Adjacente & $0-10$ \\
\hline 18 & TP18 & Adjacente & $0-10$ \\
\hline 19 & TP19 & Adjacente & $0-10$ \\
\hline 20 & TP20 & Adjacente & $0-10$ \\
\hline 21 & TP21 & Adjacente & $0-10$ \\
\hline 22 & TP22 & Adjacente & $0-10$ \\
\hline 23 & TP23 & Adjacente & $0-10$ \\
\hline 24 & TP24 & Adjacente & $0-10$ \\
\hline 25 & TP25 & Adjacente & $0-10$ \\
\hline 26 & ТP26 & Adjacente & $0-10$ \\
\hline
\end{tabular}




\begin{tabular}{|c|c|c|c|}
\hline 27 & TP27 & Adjacente & $0-10$ \\
\hline 28 & TP28 & Terra Preta & 15 \\
\hline 29 & TP29 & Terra Preta & 15 \\
\hline 30 & TP30 & Terra Preta & 15 \\
\hline 31 & TP31 & Terra Preta & 15 \\
\hline 32 & TP32 & Terra Preta & 15 \\
\hline 33 & TP33 & Terra Preta & 15 \\
\hline 34 & TP34 & Terra Preta & 15 \\
\hline 35 & TP35 & Terra Preta & 15 \\
\hline 36 & TP36 & Terra Preta & 15 \\
\hline 37 & TP37 & Terra Preta & 15 \\
\hline 38 & TP38 & Terra Preta & 15 \\
\hline 39 & TP39 & Terra Preta & 15 \\
\hline 40 & TP40 & Terra Preta & 15 \\
\hline 41 & TP41 & Terra Preta & 15 \\
\hline 42 & TP42 & Terra Preta & 15 \\
\hline 43 & TP43 & Terra Preta & 15 \\
\hline 44 & TP44 & Terra Preta & 15 \\
\hline 45 & TP45 & Terra Preta & 15 \\
\hline 46 & ТP46 & Terra Preta & 15 \\
\hline 47 & TP47 & Terra Preta & 15 \\
\hline 48 & TP48 & Terra Preta & 15 \\
\hline 49 & ТP49 & Terra Preta & 15 \\
\hline 50 & TP50 & Terra Preta & 15 \\
\hline 51 & TP51 & Terra Preta & 15 \\
\hline 52 & TP52 & Terra Preta & 15 \\
\hline 53 & TP53 & Terra Preta & 15 \\
\hline 54 & TP54 & Terra Preta & 15 \\
\hline 55 & TP55 & Terra Preta & 30 \\
\hline 56 & TP56 & Terra Preta & 30 \\
\hline 57 & TP57 & Terra Preta & 30 \\
\hline 58 & TP58 & Terra Preta & 30 \\
\hline 59 & TP59 & Terra Preta & 45 \\
\hline 60 & ТP60 & Terra Preta & 45 \\
\hline 61 & TP61 & Terra Preta & 45 \\
\hline 62 & TP62 & Terra Preta & 45 \\
\hline 63 & TP63 & Terra Preta & 45 \\
\hline 64 & TP64 & Terra Preta & 45 \\
\hline
\end{tabular}




\begin{tabular}{|c|c|c|c|}
\hline 65 & ТР65 & Terra Preta & 45 \\
\hline 66 & TP66 & Terra Preta & 45 \\
\hline 67 & TP67 & Terra Preta & 45 \\
\hline 68 & TP68 & Terra Preta & 45 \\
\hline 69 & TP69 & Terra Preta & 45 \\
\hline 70 & TP70 & Terra Preta & 45 \\
\hline 71 & TP71 & Terra Preta & 45 \\
\hline 72 & TP72 & Terra Preta & 45 \\
\hline 73 & TP73 & Terra Preta & 45 \\
\hline 74 & TP74 & Terra Preta & 45 \\
\hline 75 & TP75 & Terra Preta & 45 \\
\hline 76 & TP76 & Terra Preta & 45 \\
\hline 77 & TP77 & Terra Preta & 45 \\
\hline 78 & TP78 & Terra Preta & 45 \\
\hline 79 & TP79 & Terra Preta & 45 \\
\hline 80 & TP80 & Terra Preta & 45 \\
\hline 81 & TP81 & Terra Preta & 45 \\
\hline 82 & TP82 & Terra Preta & 45 \\
\hline 83 & TP83 & Terra Preta & 45 \\
\hline 84 & TP84 & Terra Preta & 45 \\
\hline 85 & TP85 & Terra Preta & 45 \\
\hline 86 & TP86 & Terra Preta & 45 \\
\hline 87 & TP87 & Terra Preta & 45 \\
\hline 88 & TP88 & Terra Preta & 45 \\
\hline 89 & TP89 & Terra Preta & 45 \\
\hline 90 & ТР90 & Terra Preta & 45 \\
\hline 91 & TP91 & Terra Preta & 45 \\
\hline 92 & TP92 & Terra Preta & 45 \\
\hline 93 & TP93 & Terra Preta & 45 \\
\hline 94 & TP94 & Terra Preta & 45 \\
\hline 95 & TP95 & Terra Preta & 45 \\
\hline 96 & ТР96 & Terra Preta & 45 \\
\hline 97 & TP97 & Terra Preta & 45 \\
\hline 98 & TP98 & Terra Preta & 45 \\
\hline 99 & TP99 & Terra Preta & 10 \\
\hline 100 & TP100 & Adjacente & 10 \\
\hline 101 & TP101 & Adjacente & 10 \\
\hline 102 & TP102 & Adjacente & 10 \\
\hline
\end{tabular}




\begin{tabular}{|c|c|c|c|}
\hline 103 & ТР103 & Adjacente & 10 \\
\hline 104 & TP104 & Adjacente & 10 \\
\hline 105 & TP105 & Adjacente & 10 \\
\hline 106 & TP106 & Adjacente & 10 \\
\hline 107 & TP107 & Adjacente & 10 \\
\hline 108 & TP108 & Adjacente & 10 \\
\hline 109 & TP109 & Adjacente & 10 \\
\hline 110 & TP110 & Adjacente & 10 \\
\hline 111 & TP111 & Adjacente & 10 \\
\hline 112 & TP112 & Adjacente & 10 \\
\hline 113 & TP113 & Adjacente & 10 \\
\hline 114 & TP114 & Adjacente & 10 \\
\hline 115 & TP115 & Adjacente & 10 \\
\hline 116 & TP116 & Adjacente & 10 \\
\hline 117 & TP117 & Adjacente & 10 \\
\hline 118 & TP118 & Adjacente & 10 \\
\hline 119 & TP119 & Adjacente & 10 \\
\hline 120 & TP120 & Adjacente & 10 \\
\hline 121 & TP121 & Adjacente & 10 \\
\hline 122 & TP122 & Adjacente & 10 \\
\hline 123 & TP123 & Adjacente & 10 \\
\hline 124 & TP124 & Adjacente & 10 \\
\hline 125 & TP125 & Adjacente & 10 \\
\hline 126 & TP126 & Adjacente & 10 \\
\hline 127 & TP127 & Adjacente & 10 \\
\hline 128 & TP128 & Adjacente & 10 \\
\hline 129 & TP129 & Adjacente & 10 \\
\hline 130 & TP130 & Adjacente & 10 \\
\hline 131 & TP131 & Adjacente & 10 \\
\hline 132 & TP132 & Adjacente & 10 \\
\hline 133 & TP133 & Adjacente & 10 \\
\hline 134 & TP134 & Adjacente & 10 \\
\hline 135 & TP135 & Adjacente & 20 \\
\hline 136 & TP136 & Adjacente & 20 \\
\hline 137 & TP137 & Adjacente & 20 \\
\hline 138 & TP138 & Adjacente & 20 \\
\hline 139 & TP139 & Adjacente & 20 \\
\hline 140 & TP140 & Adjacente & 20 \\
\hline
\end{tabular}




\begin{tabular}{cccc} 
Conclusão & & & \\
\hline 141 & TP141 & Adjacente & 20 \\
\hline 142 & TP142 & Adjacente & 20 \\
\hline 143 & TP143 & Adjacente & 20 \\
\hline
\end{tabular}

\subsection{Extração do DNA genômico}

O isolamento do DNA genômico dos isolados foi feito a partir de culturas líquidas (25 mL) sendo as células posteriormente coletadas por centrifugação. O DNA foi isolado de acordo com DOYLE e DOYLE (1990) conforme a seguir: $700 \mu \mathrm{L}$ do tampão de extração ( $\mathrm{NaCl}$ 1,4 M, Tris-HCl $100 \mathrm{mM}$ pH 8,0, EDTA $20 \mathrm{mM}$ pH 8,0, PVP-40 1\%, CTAB 2\%, proteinase $\mathrm{K} 100 \mu \mathrm{g} / \mathrm{ml}$ e $\beta$-mercaptoetanol $0,2 \%$ ) foram adicionados às células, seguido de re-suspensão e incubação a $65^{\circ} \mathrm{C}$ por 30 min. A suspensão foi extraída com clorofórmio:álcool isoamílico (24:1) por 3 vezes, precipitada com isopropanol, seca ao ar e ressuspendida em TE $\mathrm{pH}$ 8,0 (Tris- $\mathrm{HCl} 10 \mathrm{mM}$ e EDTA $1 \mathrm{mM}$ ). O DNA total foi quantificado através de espectofotômetro modelo Lambda Bio da Perkin Elmer. Cinco microlitros do DNA foram analisados em gel de agarose $1 \%$, utilizando como padrão de tamanho de DNA o marcador molecular 1 kb Plus DNA LadderTM (Invitrogen Life Technologies, São Paulo, Brasil). Os géis foram documentados utilizando-se o programa "Multi Analyst" do "FluorSTM Multimager" (BioRad, Hercules, Califórnia, E.U.A), bem como em espectrofotometria a $260 / 280 \mathrm{~nm}$.

\subsection{Amplificação do gene que codifica o 16S rRNA}

O gene 16S rRNA foi amplificado por PCR com os seguintes oligonucleotídeos iniciadores para o domínio Eubacteria fD1 (5'-AGAGTTTGATCCTGGCTCAG-3') e rD1 
(5'-AAGGAGGTGATCCAGCC-3') (WEISBURG et al., 1991). Amplificações do gene 16S rRNA por PCR foram feitas em volume de $50 \mu \mathrm{L}$ contendo 5 pmols de oligonucleotídeos iniciadores, $200 \mu \mathrm{M}$ de cada dNTP, $1 \mathrm{X}$ tampão Taq, 1,5 mM de MgCl2, 2 U Platinum Taq DNA polimerase (Invitrogen Life Technologies, São Paulo, Brasil) e 50 ng de DNA.

A PCR foi realizada no termociclador de modelo GeneAmp PCR System 9700 - Aplied Biosytem com o seguinte ciclo: 3 min. de desnaturação a $94^{\circ} \mathrm{C}$, seguido de 30 ciclos com desnaturação a $94^{\circ} \mathrm{C}$ por 1 min., anelamento a $55^{\circ} \mathrm{C}$ por $30 \mathrm{seg}$., extensão a $72^{\circ} \mathrm{C}$ por $30 \mathrm{seg}$. e extensão final a $72^{\circ} \mathrm{C}$ por 10 min. Uma alíquota de $5 \mu \mathrm{L}$ do produto da PCR foi analisada em gel de agarose $1 \%$, utilizando como padrão de tamanho de DNA o marcador molecular 100 pb (Invitrogen Life Technologies, São Paulo, Brasil). Os géis foram documentados através do programa "Multi Analyst" do "Fluor-STM Multimager" (BioRad, Hercules, Califórnia, E.U.A).

\subsection{Purificação do DNA}

A purificação do DNA foi efetuada da seguinte forma: todo o volume do produto de PCR $(45 \mu \mathrm{L})$ foi transferido para tubos Eppendorf de $500 \mu \mathrm{L}$ e adicionados $135 \mu \mathrm{L}$ de isopropanol $100 \%$ e $45 \mu \mathrm{L}$ de água ultrapura (Ex: milli-Q) autoclavada. A mistura foi homogeneizada (vórtex) por alguns segundos. Foi deixado em repouso por $2 \mathrm{~h} \mathrm{a}-20^{\circ} \mathrm{C}$; em seguida foi centrifugada a $20.800 \times g$ por 25 min., a temperatura ambiente. O sobrenadante foi descartado totalmente e adicionado $250 \mu \mathrm{L}$ de etanol $70 \%$ (diluído em água ultrapura imediatamente antes de usar). Homogeneizou-se (vórtex) por alguns segundos e centrifugouse a $20.800 \times g$ por 5 min., a temperatura ambiente; o sobrenadante foi descartado totalmente e o precipitado foi secado no concentrador de DNA por 10 min. e ressuspendido em $50 \mu \mathrm{L}$ de 
água ultrapura autoclavada. Agitou-se em vórtex seguido de um pulso na microcentrífuga; o material $(5 \mu \mathrm{L})$ foi colocado em gel de agarose $1 \%$ e o restante foi armazenado em freezer $20^{\circ} \mathrm{C}$ até a próxima etapa (digestão com enzimas de restrição).

\subsection{Análise de Restrição do DNA Ribossomal Amplificado (ARDRA)}

As reações de digestão foram realizadas utilizando-se aproximadamente $500 \mathrm{ng}$ do produto de PCR resultante da amplificação do gene 16S rRNA universal purificado: 2,0 $\mu \mathrm{L}$ do tampão da enzima, $0,3 \mu \mathrm{L}$ da enzima de restrição $(10 \mathrm{U} / \mu \mathrm{L})$ em volume final de $20 \mu \mathrm{L}$. As reações foram incubadas a $65^{\circ} \mathrm{C}$ para as enzimas $T a q$ I, $M s p$ I e $R S A$ I. Todo o produto de PCR foi analisado em gel de agarose 1,7\%, utilizando como padrão de tamanho de DNA o marcador molecular $1 \mathrm{~Kb}$ Plus DNA LadderTM (Invitrogen Life Technologies). Os géis foram documentados pelo programa "Multi Analyst" do "Flúor-S ${ }^{\mathrm{TM}}$ Multimager" (BioRad, Hercules, Califórnia, E.U.A).

A seguir, encontram-se descritas as enzimas de restrição (endonuclease) utilizadas neste estudo, com suas respectivas seqüências de corte:

$\operatorname{Taq}$ I: $\quad 5^{\prime}-\mathrm{T} \downarrow \mathrm{CG} \mathrm{A}-3$ '

$$
\text { 3' - A GC } \uparrow \mathrm{T}-5 \text {, }
$$

$\boldsymbol{R s a}$ I: $\quad 5^{\prime}-\mathrm{G} \mathrm{T} \downarrow$ A C - 3'

\footnotetext{
3'- C A $\uparrow$ T G - 5'

Rsa I: 5 '-
}

$\operatorname{Msp} \mathbf{I}: 5^{\prime}-\mathrm{C} \downarrow \mathrm{CG} \mathrm{G}-3$ '

$$
3^{\prime}-\mathrm{G} \mathrm{GC} \uparrow \mathrm{C}-5^{\prime}
$$




\subsection{Seqüenciamento do Gene 16S rRNA}

A PCR de seqüenciamento dos fragmentos foi feita através do kit de seqüenciamento DYEnamic ET Terminator Cycle (Amersham Biosciences, Inglaterra, UK). A reação foi para um volume final de $10 \mu \mathrm{L}$ onde foram utilizados $200 \mathrm{ng}$ dos fragmentos de interesse; 5 pmoles de oligonucleotídeos iniciadores; $2,0 \mu \mathrm{L}$ de tampão 2,5 X; 2,0 $\mu \mathrm{L}$ de DYEnamic ET Terminator Cycle. Os oligonucleotídeos iniciadores utilizados foram: rD1 e fD1, além dos conjuntos de oligonucleotídeos internos descritos na Tabela 3, visando o fechamento da seqüência do gene 16S rRNA. As condições de amplificação para o iniciador T7 foram: 2 min. de desnaturação a $96^{\circ} \mathrm{C}$, seguidos de 25 ciclos com desnaturação a $96^{\circ} \mathrm{C}$ por 45 seg., anelamento a $50^{\circ} \mathrm{C}$ por $30 \mathrm{seg}$., extensão a $60^{\circ} \mathrm{C}$ por $4 \mathrm{~min}$., enquanto que para os demais iniciadores tais condições encontram-se a seguir: 4 min. de desnaturação a $94^{\circ} \mathrm{C}$, seguidos de 25 ciclos com desnaturação a $94^{\circ} \mathrm{C}$, por 1 min.; anelamento a $55^{\circ} \mathrm{C}$ por $30 \mathrm{seg}$. e extensão a $60^{\circ} \mathrm{C}$ por $4 \min$.

Tabela 3- Sequiências dos oligonucleotídeos iniciadores internos para amplificação do gene.

\begin{tabular}{cc}
\hline \hline Seqüência $\left(\mathbf{5}^{\prime} \mathbf{- 3}^{\prime}\right)$ & $\begin{array}{c}\text { Posição de alinhamento na } \\
\text { seqüência de } \boldsymbol{E} \text {. coli }\end{array}$ \\
\hline \hline AGA GTT TGA TCC TGC CTC AG & $8-28$ FDI eubactéria \\
\hline AAG GAG GTG ATC CAG CC & $1526-1542 \mathrm{RDI}$ eubactéria \\
\hline CCT ACG GGA GGC AGC AG & $341-357 \mathrm{~F}$ \\
\hline CTG CTG CCT CCC GTA GG & $357 \mathrm{R}$ \\
\hline TTA G(GC)G GTG AAA T(GC)C GTA GA & $685-704 \mathrm{~F}$ \\
\hline GCA ACG AGC GCA ACC C & $704 \mathrm{R}$ \\
\hline GGG TTG CGC TCG TTG C & $1099-1114 \mathrm{~F}$ \\
\hline \hline
\end{tabular}


Após a amplificação dos fragmentos de interesse, procedeu-se a precipitação para a eliminação dos dNTPs que não foram incorporados. Foram adicionados $1 \mu \mathrm{L}$ de tampão acetato de sódio/EDTA, mais $40 \mu \mathrm{L}$ etanol a 95\% (recém preparado). Após a homogeneização por agitação, os tubos foram centrifugados a $12.000 \mathrm{rpm}$, por $15 \mathrm{~min}$., a temperatura ambiente. O sobrenadante foi descartado e $500 \mu \mathrm{L}$ de etanol $70 \%$ foram adicionados. Após a homogeneização, as amostras foram centrifugadas por 5 min. a $12.000 \mathrm{rpm}$. O sobrenadante foi descartado e o precipitado incubado por $5 \mathrm{~min}$. a $40^{\circ} \mathrm{C}$ para secagem. Em seguida o precipitado foi ressuspendido em $10 \mu \mathrm{L}$ de formamida (HiDi formamida - Applied Biosystems) em microplacas. A microplaca foi colocada em um termociclador para a desnaturação do DNA a $96^{\circ} \mathrm{C}$ durante 5 min. e imediatamente colocada no gelo por 2 min. A leitura das bases marcadas foi realizada no Seqüenciador Automático ABI Prism 3100 Genetic Analyser do departamento de Ciências Biológicas no Laboratório Biologia Celular de Plantas - ESALQ/USP.

\subsection{Processamento e análise filogenética das seqüiências}

As seqüências geradas foram processadas removendo-se as bases de baixa qualidade $(<20)$ através dos programas Phred/Phrap/Consed em sistema operacional Linux (EWING; GREEN, 1998; EWING et al., 1998; GORDON et al., 1998). As seqüências obtidas foram comparadas com outras seqüências previamente depositadas no GenBank do National Center for Biotechnology Information (NCBI), utilizando-se a ferramenta Basic Local Aligment Search Tool (BLAST) (ALTSCHUL et al., 1990). A construção e visualização da árvore filogenética foi realizada com o auxílio do programa Mega 3.1 (KUMAR et al., 2004). O alinhamento das seqüências foi realizado através do programa Clustal W 1.8 (http://www.ebi.ac.uk/index.html) (THOMPSON et al., 1994). Posteriormente, o ajuste das 
extremidades das seqüências de DNA, de forma que todas elas tivessem o mesmo número de bases e estivessem completamente alinhadas foi realizado com o auxílio do programa BioEdit (HALL, 2001). Para o cálculo da significância estatística da similaridade entre as sequiências foi utilizada uma re-amostragem para 1000 replicações (SWOFFORD et al., 1996). O método de distância ("Neighbour Joining”) (SAITOU; NEI, 1987) foi usado na construção da árvore filogenética.

\subsection{Distribuição dos genes de NRPS e PKS}

Para amplificação de seqüências conservadas de NRPS e PKS, utilizou-se um conjunto de oligonucleotídeos iniciadores descritos na Tabela 4, confeccionado pela Integrated DNA Technologies, Inc. (Integrated DNA Technologies, INC., Coralville, IA, EUA). A amplificação foi feita em solução contendo: tampão para a reação PCR 1 X (Tris HCl 20 mM pH 8,4; KCl $50 \mathrm{mM}$ ); 0,2 mM de cada dNTP; $\mathrm{MgCl}_{2} 5 \mathrm{mM} ; 1,5 \mathrm{U}$ de Platinum® Taq DNA Polimerase (Invitrogen); $10 \mathrm{ng}$ de DNA; 5 pmol de cada iniciador; 4\% de DMSO (dimetilsulfóxido); água ultrapura (Milli-Q) esterilizada, para um volume final de $25 \mu \mathrm{L}$. A reação foi feita em um termociclador "Gene Amp PCR System 2400” (Applied Biosystems), nas seguintes condições: $94^{\circ} \mathrm{C} / 2 \mathrm{~min} ; 5$ ciclos de $94^{\circ} \mathrm{C} / 1 \mathrm{~min}, 45^{\circ} \mathrm{C} / 1 \mathrm{~min}, 72^{\circ} \mathrm{C} / 1 \mathrm{~min} ; 30$ ciclos de $94^{\circ} \mathrm{C} / 30 \mathrm{~s}, 50^{\circ} \mathrm{C} / 1 \mathrm{~min}, 72^{\circ} \mathrm{C} / 4 \mathrm{~min}$; extensão final a $72^{\circ} \mathrm{C} / 15 \mathrm{~min}$.

Uma alíquota de $5 \mu \mathrm{L}$ do produto da PCR foi analisada em gel de agarose $1 \%$, utilizando como padrão de tamanho de DNA o marcador molecular 100 pb (Invitrogen Life Technologies, São Paulo, Brasil). Os géis foram documentados através do programa "Multi Analyst” do "Fluor-S ${ }^{\mathrm{TM}}$ Multimager" (BioRad, Hercules, Califórnia, E.U.A). 
Tabela 4- Iniciadores de reação que foram utilizados na amplificação de PCR.

\begin{tabular}{cll} 
Iniciador & \multicolumn{1}{c}{ Sequiência no sentido 5'-3' } & Referência \\
\hline \hline & & \\
MTF & GCN GGY GGY GCN TAY GTN CC & NEILAN et al. (1999) \\
MTR & CCN CGD ATY TTN ACY TG & NEILAN et al. (1999) \\
KS $^{+}$ & MGI GAR GCI HWI SMI ATG GAY CCI CAR CAI MG & BEYER et al. (1999) \\
KS $^{-}$ & GGR TCI CCI ARI SWI GTI CCI GTI CCR TG & BEYER et al. (1999) \\
\hline \hline
\end{tabular}

\subsection{Produção de sideróforo em meio sólido}

A produção de sideróforos foi verificada para as 143 linhagens descritas na Tabela 2. A análise de cromoazurol S (CAS) ágar foi realizada conforme a seguir (SCHWIN; NEILANDS, 1987): 60,5 mg de CAS foram dissolvidos em $50 \mathrm{ml}$ de água destilada e misturada com $10 \mathrm{ml}$ de ferro (III) $\left(\mathrm{FeCl}_{3} \bullet 6 \mathrm{H}_{2} \mathrm{O} 1 \mathrm{mM}\right.$ em $\left.\mathrm{HCl} 10 \mathrm{mM}\right)$. Sob agitação, esta solução foi vagarosamente adicionada a 72,9 mg de HDTMA (hexadecyltrimethylammonium) dissolvido em $40 \mathrm{ml}$ de água. Estas soluções foram autoclavadas separadamente. Separadamente também foi autoclavado um meio de cultura deficiente em ferro (MM9) de acordo com PAYNE (1994), modificado por SILVA-STENICO et al. (2005). O meio era composto de (1 L): $\mathrm{KH}_{2} \mathrm{PO}_{4} 0,3 \mathrm{~g} \mathrm{~L}^{-1}, \mathrm{NaCl} 0,5 \mathrm{~g} \mathrm{~L}^{-1}, \mathrm{NH}_{4} \mathrm{Cl} 1,0 \mathrm{~g} \mathrm{~L}{ }^{-1}$. Em $100 \mathrm{ml}$ desta solução foram adicionados $1,2 \mathrm{~g}$ de Tris e $18 \mathrm{~g}$ de agar, $\mathrm{pH}$ 5.6, completado para $1 \mathrm{~L} \mathrm{e}$ autoclavada. Esta solução foi suplementada com $30 \mathrm{ml}$ de casaminoácido desferrado $10 \%$ (m/v) (o ferro contaminante foi removido com 3\% de 8-hidroxiquinolina em clorofórmio), manitol $2 \mathrm{~g} / \mathrm{L}, 1 \mathrm{ml}$ de $\mathrm{MgCl}_{2} 1 \mathrm{M}$ e $1 \mathrm{ml}$ de $\mathrm{CaCl}_{2} 100 \mathrm{mM}$. Estas soluções foram preparadas e filtradas em filtro Millipore $0,22 \mu$. A solução de CAS foi adicionada ao meio MM9 e as placas foram inoculadas com linhagens de culturas estoques e incubadas a $28^{\circ} \mathrm{C}$. A mudança 
de cor de azul para amarelo do meio CAS foi anotada. Toda a vidraria utilizada foi lavada com $\mathrm{HCl} 6 \mathrm{~N}$ para retirada de ferro contaminante.

\subsection{Detecção de sideróforo em solução pelo método do CAS}

Seis mililitros de HDTMA $10 \mathrm{mM}$ foram adicionados em balão volumétrico de $100 \mathrm{ml} \mathrm{e}$ diluído com água. Uma mistura de 1,5 ml de ferro(III) (1 mM FeCl $\left.\mathrm{ma} \mathrm{HCl}_{3} 10 \mathrm{mM}\right)$ e 7,5 ml de solução de CAS (2 mM) foi cuidadosamente adicionada ao balão volumétrico. Piperazina anidra 4,307 $\mathrm{g}$ foi dissolvida em água e $6,25 \mathrm{ml}$ de $\mathrm{HCl} 12 \mathrm{M}$ foram adicionados. Esta solução (pH 5,6) foi adicionada ao balão volumétrico até completar os $100 \mathrm{ml}$. Esta solução foi estocada em ausência de luz. Uma alíquota de $0,5 \mathrm{ml}$ da solução de sideróforo ou sobrenadante de cada cultura foi misturada com $0,5 \mathrm{ml}$ da solução de CAS (A). Um branco $\left(\mathrm{A}_{\mathrm{ref}}\right)$ foi preparado usando exatamente os mesmos componentes, menos o sideróforo (p.e. o meio não inoculado usado para a cultura das bactérias). Após atingir o equilíbrio, a absorbância foi lida a $630 \mathrm{~nm}$. O cálculo da produção de sideróforo foi realizado da seguinte maneira: A/A $\mathrm{A}_{\text {ref }}\left(\mathrm{A}=\right.$ absorbância da amostra, $\mathrm{A}_{\text {ref }}=$ absorbância do branco $)$.

\subsection{Análise de sideróforos - propriedades químicas}

Para estas análises todos os isolados foram cultivados em meio líquido MM9. O crescimento celular foi medido pela densidade ótica a $600 \mathrm{~nm}\left(\mathrm{DO}_{600}\right)$ em espectrofotômetro Perkin-Elmer. A bactéria foi proveniente de um inóculo padrão (100 $\mu 1$ de uma suspensão com absorbância a $600 \mathrm{~nm}$ de 0,5 ) em frascos de $10 \mathrm{ml}$ contendo $50 \mathrm{ml}$ de meio MM9 e incubado a $28^{\circ} \mathrm{C}$ em shaker a $150 \mathrm{rpm}$. As culturas foram centrifugadas e os sobrenadantes 
utilizados para os ensaios. As linhagens TP26, TP27 e TP122 foram utilizadas como controle negativo, uma vez que não apresentaram halo no teste de CAS-agar para sideróforo.

Para detectar a análise funcional do sideróforo, dois testes foram realizados:

\subsubsection{Análise pelo método de CSÁKY (1948)}

Essa análise identifica sideróforos do tipo hidroxamato. Uma curva padrão foi realizada utilizando hidroxilamina em concentrações de 10 a $400 \mu \mathrm{M}$. O sobrenadante $(1 \mathrm{ml})$ da cultura foi hidrolizado com $1 \mathrm{ml}$ de $\mathrm{H}_{2} \mathrm{SO}_{4} 6 \mathrm{~N}$ em digestor por 30 min a $130^{\circ} \mathrm{C}$. A solução foi então tamponada adicionando $3 \mathrm{ml}$ da solução de acetato de sódio 35\%. Então, foi adicionado $1 \mathrm{ml}$ da solução de ácido sulfanílico $1 \%$ seguido por $0,5 \mathrm{ml}$ de solução de iodina $1,3 \%$. Após 5 min., o excesso de iodina foi destruído com $1 \mathrm{ml}$ da solução de arsenito de sódio 2\%. Um ml de $\alpha$-naftalamina $0,15 \%$ foi adicionado. A cor se forma entre 20 e 30 min. A absorbância foi lida a $526 \mathrm{~nm}$.

\subsubsection{Análise pelo método de ARNOW (1937)}

Esta análise é destinada para sideróforos da classe catecol. Uma curva padrão foi realizada utilizando ácido hidroxibenzóico em concentrações de 10 a $590 \mu \mathrm{M}$. Para $1 \mathrm{ml}$ de sobrenadante ou solução de sideróforo, foi adicionado na seguinte ordem misturando após cada adição: $1 \mathrm{ml}$ de $\mathrm{HCl}$ 0,5 N, $1 \mathrm{ml}$ de nitrito-molibdato $10 \%$ e $1 \mathrm{ml}$ de $\mathrm{NaOH} 1 \mathrm{~N}$. A cor é estável por 1 h e a solução tem absorção máxima a $510 \mathrm{~nm}$. 


\subsection{Estudo da linhagem Pseudomonas putida TP11}

Testes preliminares foram realizados com $P$. putida TP11 para identificação de sideróforo através de espectrometria de massas (ESI-Q-TOF).

\subsubsection{Extração do composto}

Para esta análise $P$. putida TP11 foi inoculada em uma placa contendo MM9-CAS-agar até a formação do halo amarelo (indicador da presença de sideróforo). Então uma área de 1 $\mathrm{cm}^{2}$ foi recortada da placa contendo o halo amarelo e para o controle foi recortada a parte azul (Figura 7). A metodologia empregada deu-se da seguinte maneira: as regiões recortadas das placas de CAS contendo halos produzidos pela bactéria foram diluídas em $1 \mathrm{ml}$ de água destilada acidificada ( $\mathrm{pH}$ 2) e adicionado $1 \mathrm{ml}$ de acetato de etila. A fase orgânica foi coletada para uso posterior.

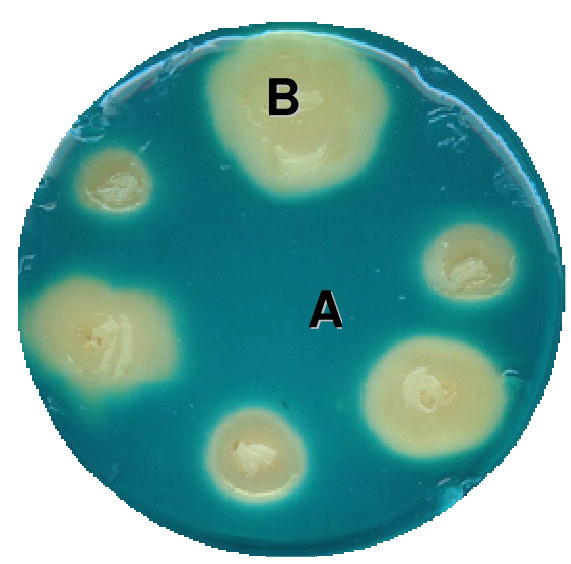

Figura 7. Teste do CAS-agar para análise em espectrometria de massas. As letras (A e B) indicam as áreas que foram recortadas da placa para extração do composto. A) Área usada como controle (sem crescimento bacteriano); B) Área que apresentou produção de sideróforos e formação de halos ao redor das colônias. 


\subsubsection{Espectrometria de massas}

Esta análise foi realizada no Instituto de Química, Univers. Estadual de Campinas (UNICAMP) em colaboração com o Dr. Marcos Nogueira Eberlin e Dr. Luis Alberto Beraldo de Moraes (USP-RP). A fase orgânica foi separada e analisada em espectrometria de massas usando um Q-Tof (Micromass, Manchester, UK) híbrido de alta resolução (7.000) e alta precisão (5 ppm) equipado com uma fonte de ionização por electrospray (ESI). As condições para a ESI no modo positivo foram as seguintes: gás de dessolvatação (nitrogênio) foi aquecido a $150^{\circ} \mathrm{C}$; o capilar foi mantido a um potencial de $3.5 \mathrm{kV}$ e a voltagem do cone foi de $25 \mathrm{kV}$. A fragmentação do peptídeo (MS/MS tandem) foi adquirida selecionando-se o íon com a MM alvo usando o analisador de massas quadrupolo seguido de $20 \mathrm{eV}$, dissociação de colisão induzida usando argônio na célula de colisão do quadrupolo e análise de massas pelo TOF. Os extratos foram dissolvidos em uma mistura de metanol:água (1:1 v/v). As amostras foram introduzidas na fonte a $5 \mu \mathrm{L} / \mathrm{min}$ com uma seringa.

\subsection{Estudo da linhagem Pseudomonas putida TP16}

A linhagem TP16 foi escolhida para este estudo por possuir sideróforos da classe catecol e hidroxamato e apresentar atividade antimicrobiana.

\subsubsection{Bioensaios}

Um pré-inóculo foi preparado a partir de $300 \mathrm{ml}$ de meio líquido MM9, contendo manitol $0,5 \%$. Este pré-inóculo (cultivado por $24 \mathrm{~h}$ ) foi centrifugado e as células foram inoculadas em $3 \mathrm{~L}$ de meio MM9 sob agitação a $28^{\circ} \mathrm{C}$. Após a cultura atingir a fase 
exponencial de crescimento, $500 \mathrm{ml}$ de cultura foram centrifugados e o sobrenadante separado em 2 frações de $250 \mathrm{ml}$ para a extração de compostos bioativos extracelulares. Para cada fração foi adicionado um solvente: clorofórmio e acetato de etila para se testar a melhor eficiência de separação dos compostos. A fase orgânica foi coletada e evaporada até $2 \mathrm{ml}$. O meio líquido MM9 também foi extraído em acetato de etila e clorofórmio na mesma proporção das amostras. Estes extratos foram utilizados para atividade antimicrobiana. Extratos orgânicos das culturas foram utilizados em bioensaios em placas de Petri contendo linhagens selecionadas de bactérias e fungos fitopatogênicos, da coleção de isolados do Laboratório de Biologia Celular e Molecular (CENA-USP), entre eles: Bacillus subtilis, Salmonella typhimurium, Micrococcus luteus, Staphylococcus pasteuri, Bacillus cereus, Paracoccus sp e Staphylococcus aureus, os fungos Sclerotium rolfsii e Rhizoctonia solani e a levedura Candida cruzeii. As bactérias foram inoculadas em meio LB (Luria-Bertani) (BERTANI, 1951), os fungos em extrato de malte 3\% e a levedura em meio YM (extrato de levedura-manitol) (VINCENT, 1970).

Os testes consistiram em colocar discos de filtro de papel $(6 \mathrm{~mm} \varnothing)$ esterilizados contendo $20 \mu \mathrm{L}$ do extrato orgânico em placas inoculadas com os microrganismos testes. As placas foram inoculadas por $24 \mathrm{~h}$ a $28^{\circ} \mathrm{C}$ para bactérias e levedura e por 7 dias a $30^{\circ} \mathrm{C}$ para os fungo. Resultados positivos foram visualizados pelo aparecimento de zonas de inibição de crescimento. 


\subsubsection{Análise da produção de sideróforos}

O cultivo da bactéria foi o mesmo descrito no item anterior. Coletas de alíquotas foram realizadas a cada 12 h para análise do crescimento celular (OD 600nm) e sideróforos (CAS líquido).

\subsubsection{Cromatografia em camada delgada (CCD)}

A CCD foi realizada para avaliação analítica qualitativa dos componentes dos extratos orgânicos, utilizando-se cromatoplacas de sílica $\mathrm{GF}_{254}$ em suporte de alumínio, da MERCK. O solvente de eluição usado foi uma mistura de hexano:acetato de etila:ácido acético (55:45:0.1) $(\mathrm{v} / \mathrm{v})$.

Os extratos orgânicos obtidos no item 3.15.1 foram aplicados nas cromatoplacas na quantidade $10 \mu 1$, tendo sido aplicado o controle (extrato do meio de cultura) como referência. As bandas foram identificadas sob luz ultravioleta no comprimento de onda de $254 \mathrm{~nm}$ e 366 nm e o cálculo dos Rfs (fator de retenção) segundo a seguinte equação:

$$
\mathrm{R}_{\mathrm{f}}=\text { Distância do centro da banda à linha de partida }
$$

Distância da frente do eluente à linha de partida 


\subsubsection{Espectrometria de massas (Q-TOF)}

A metodologia empregada para a espectrometria de massas foi a mesma descrita no item 3.14.2. Os extratos orgânicos obtidos no item 3.15.1 foram introduzidos na fonte a 5 $\mu \mathrm{L} / \mathrm{min}$ com uma seringa. 


\section{RESULTADOS E DISCUSSÃO}

\subsection{Extração de DNA genômico}

Foram isoladas em média 20 colônias de bactérias de cada amostra de solo, totalizando um número de 143 isolados. As extrações de DNAs genômicos das culturas puras foram realizadas com sucesso usando o protocolo descrito por DOYLE e DOYLE (1990). A concentração e a pureza desses DNAs foram determinadas em espectrofotômetro. Em seguida, os DNAs totais foram diluídos para padronização, para um total de 10 ng/ $\mu 1$ de DNA.

\subsection{Amplificação do gene 16S rRNA}

Os DNAs totais foram amplificados por PCR com os oligonucleotídeos iniciadores do gene ribossomal 16S para o Domínio Eubacteria fD1 e rD1. Os produtos de PCR de todos os isolados foram purificados usando-se precipitação por isopropanol e então ressuspendidos em água ultrapura esterilizada. Amplificações do gene 16S rRNA por PCR confirmaram a presença de bactérias entre os isolados.

A plasticidade genética das bactérias, que permite transferência do DNA através dos plasmídeos, bacteriófagos e transposons, complica a identificação da espécie bacteriana. Os métodos para medir a diversidade microbiana no solo podem ser categorizados em dois grupos: técnicas bioquímicas e técnicas moleculares. Conseqüentemente, muitas outras técnicas foram desenvolvidas para avaliar a diversidade microbiana da comunidade. Nestes métodos, o DNA é extraído da amostra ambiental e purificado. O DNA alvo (16S, 18S ou ITS) é amplificado usando iniciadores universais ou específicos e os produtos resultantes são 
separados de maneiras diferentes (WOESE et al. 1990; KIRK et al., 2004). A amplificação de seqüências correspondentes ao gene ribossomal $16 \mathrm{~S}$ produziu uma banda única em torno de $1500 \mathrm{pb}$ para todas as linhagens testadas (Figura 8). 

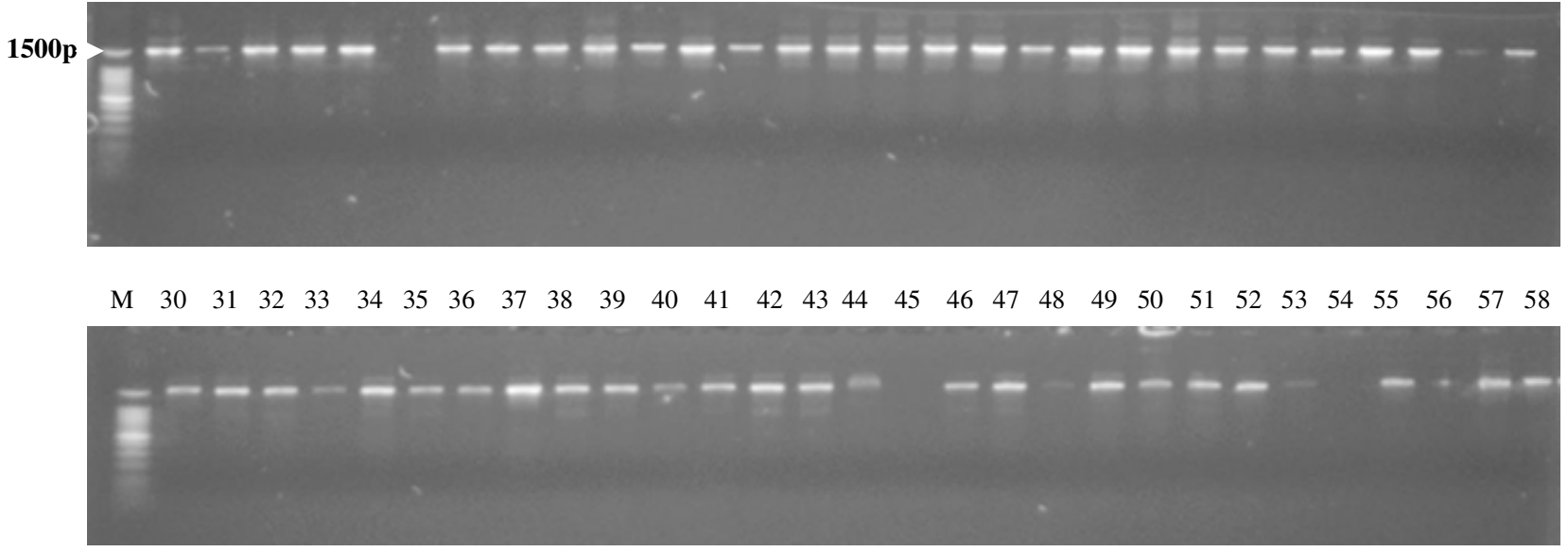

$\begin{array}{llllllllllllllllllllllllllllll}\text { M } & 59 & 60 & 61 & 62 & 63 & 64 & 65 & 66 & 67 & 68 & 69 & 70 & 71 & 72 & 73 & 74 & 75 & 76 & 77 & 78 & 79 & 80 & 81 & 82 & 83 & 84 & 85 & 86 & 87\end{array}$

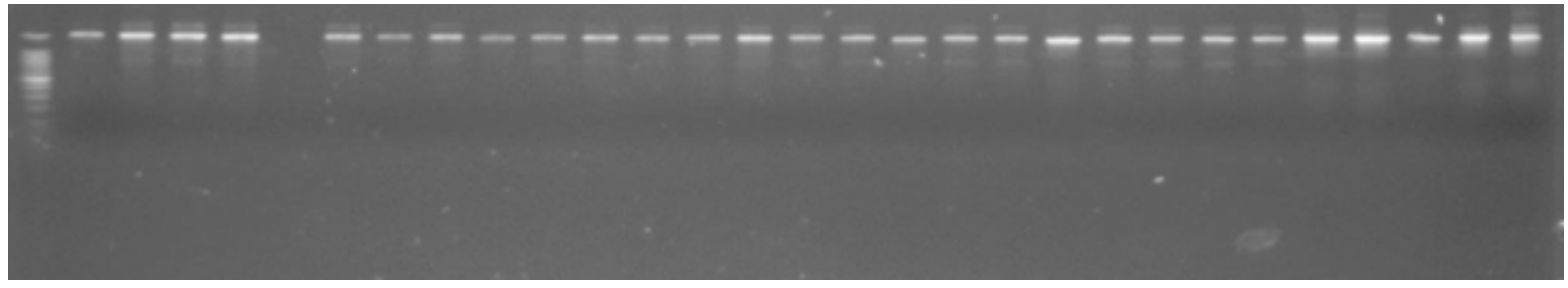

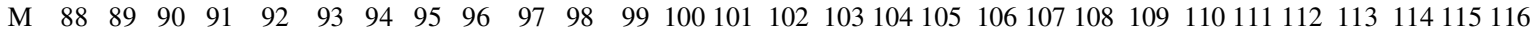

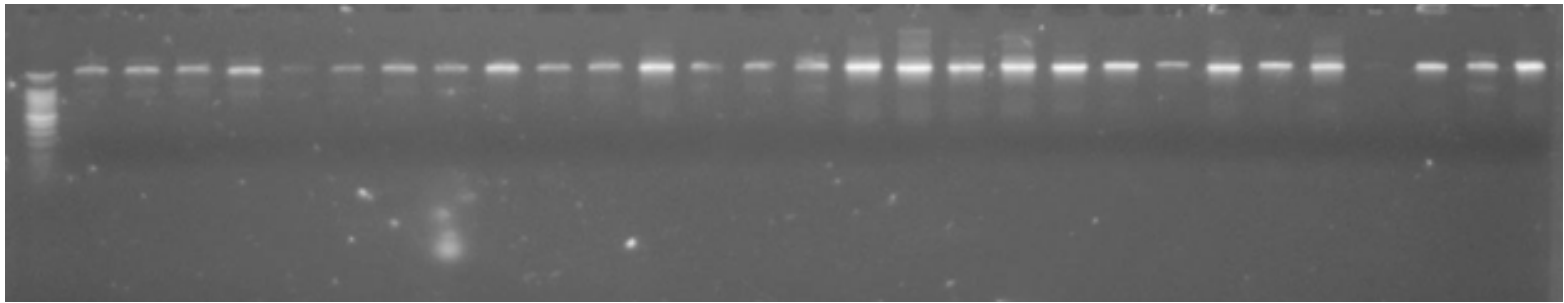

M 117118119120121122123124125126127128129130131132133134135136137138139140141142143 B

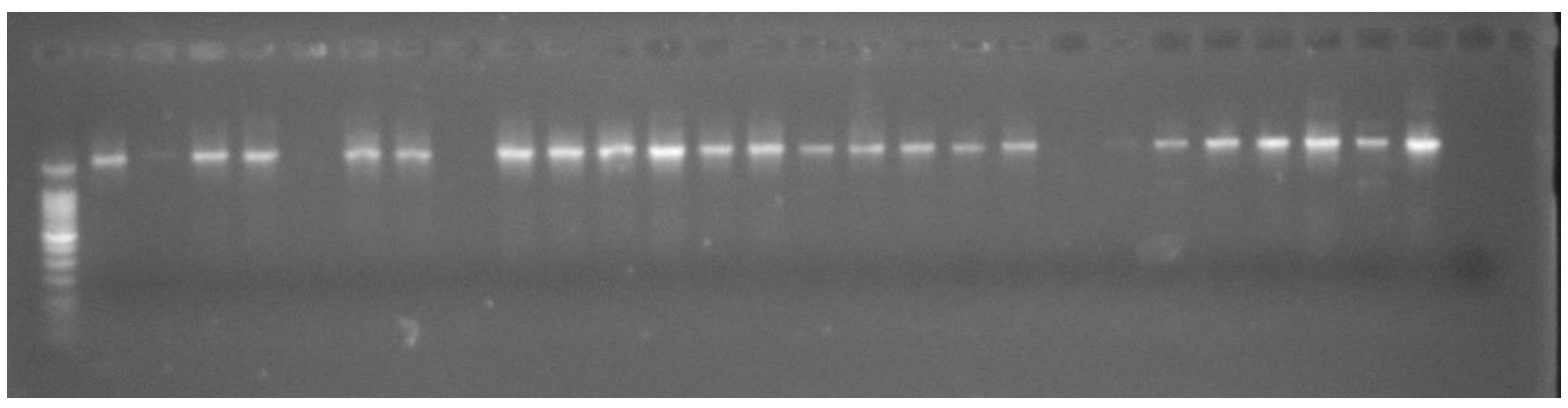

Figura 8. Eletroforese em gel de agarose $1 \%$ com produtos de amplificação (oligonucleotídeos iniciadores específicos para o gene ribossomal 16S rRNA). M) marcador molecular $100 \mathrm{pb}$; B) controle negativo (sem DNA). Os números acima das canaletas correspondem aos isolados indicados na Tabela 2. 


\subsection{Análise de restrição de DNA ribossomal amplificado (ARDRA)}

Posteriormente os produtos de PCR foram submetidos à técnica de restrição de seqüências amplificadas do gene $16 \mathrm{~S}$ rRNA (ARDRA) com o propósito de detectar a variabilidade genética entre os isolados de bactérias de cada amostra de solo. De acordo com o padrão de clivagem obtido, foi possível observar de 2 a 4 fragmentos por enzima de restrição (Figura 9). Fragmentos com tamanho acima de 100 pb foram considerados na presente análise. De acordo com o padrão de clivagem utilizado destas enzimas, foi possível observar polimorfismos entre os isolados deste estudo.

O valor deste método está na sua rapidez e habilidade para avaliar diferenças entre grupos filogenéticos, efetuando análises em vários níveis de classificação (JORGENSEN; CLUSTER, 1989). 
$\begin{array}{llllllllllllllllllllllllllllll}\mathrm{M} & 1 & 2 & 3 & 4 & 5 & 7 & 8 & 9 & 10 & 11 & 12 & 13 & 14 & 15 & 16 & 17 & 18 & 19 & 20 & 21 & 22 & 23 & 24 & 25 & 26 & 27 & 29 & 30 & \mathrm{M}\end{array}$

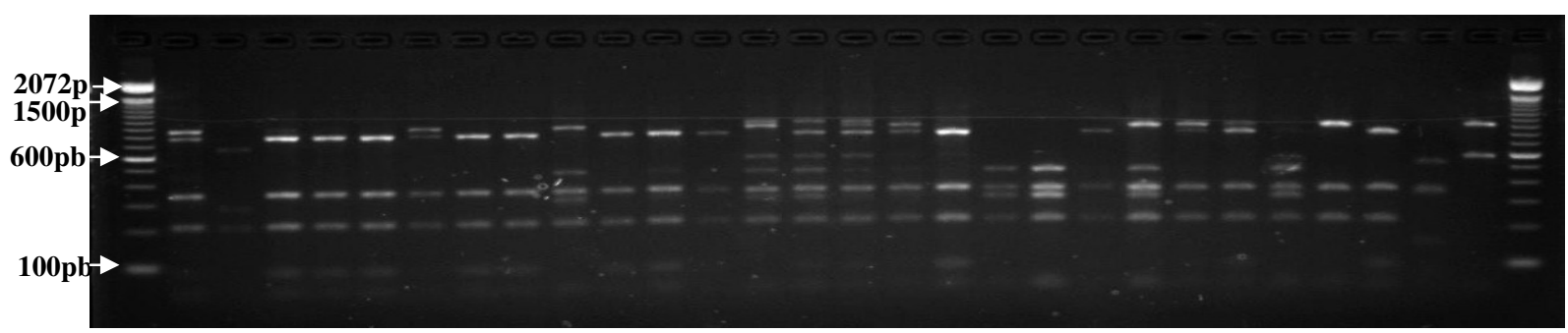

$\begin{array}{llllllllllllllllllllllllllllll}\text { M } & 31 & 32 & 33 & 34 & 35 & 36 & 37 & 38 & 39 & 40 & 41 & 42 & 43 & 46 & 47 & 49 & 50 & 51 & 52 & 55 & 57 & 58 & 59 & 60 & 61 & 62 & 64 & 65 & M\end{array}$

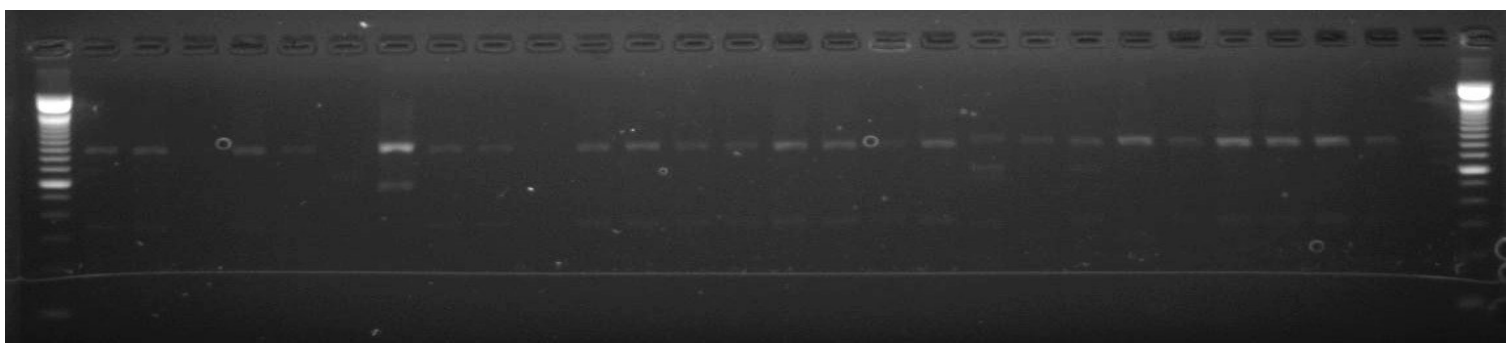

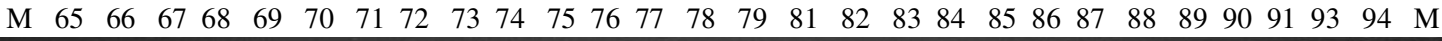

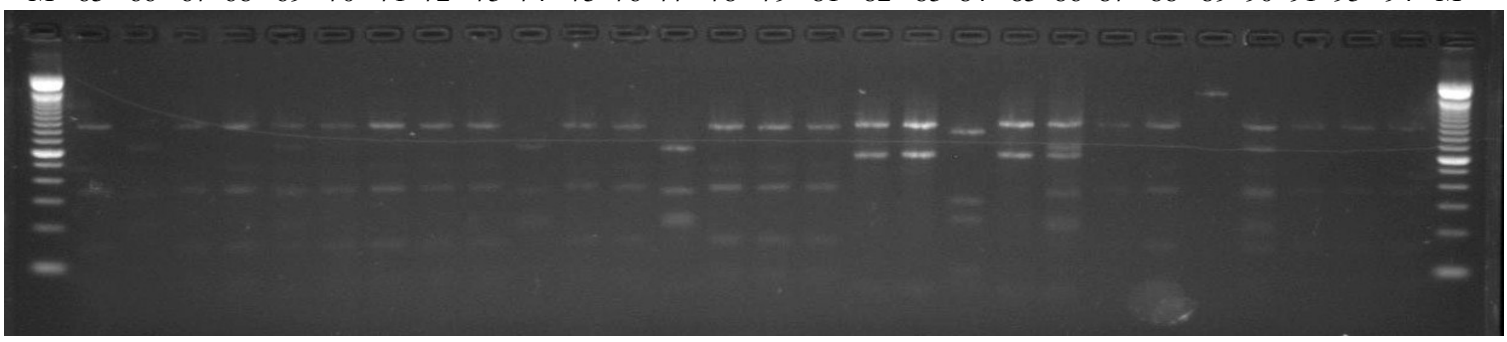

M 9596979899100101102103104105106107108109110111112114115116117118119120122123125 M
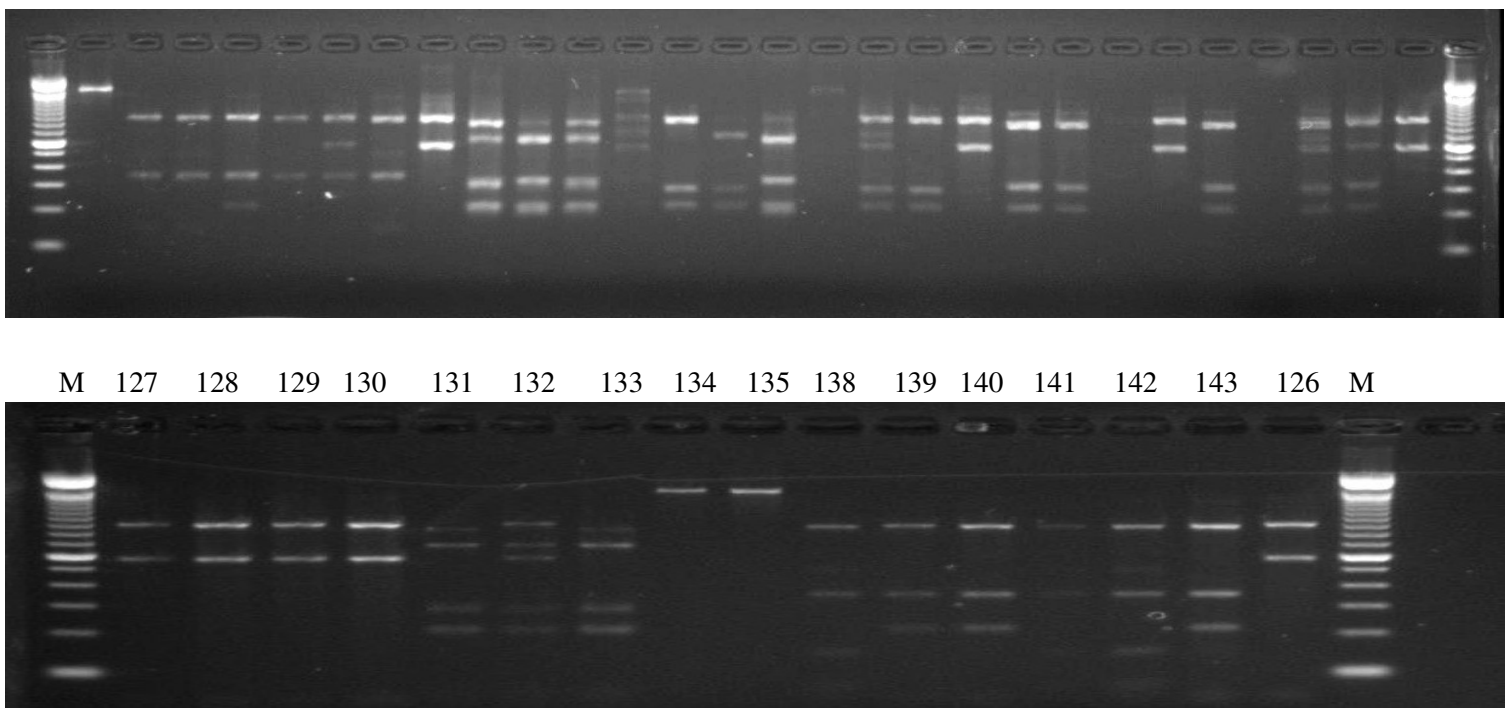

Figura 9. Eletroforese em gel de agarose $1,7 \%$ com produtos de digestão enzimática com a endonuclease Taq I após a amplificação do gene 16S rRNA. M - marcador molecular $1 \mathrm{~Kb}$ Ladder. Os números acima das canaletas correspondem aos isolados de TPA, conforme a numeração da Tabela 2. 
De acordo com a Figura 9 alguns isolados não apresentaram padrões de restrição, portanto um segundo grupo de enzimas $R s a \mathrm{I}$ e $M s p \mathrm{I}$ foi testado para estes isolados a fim de se observar o perfil de restrição (Figura 10).

\section{Rsa I (a)}

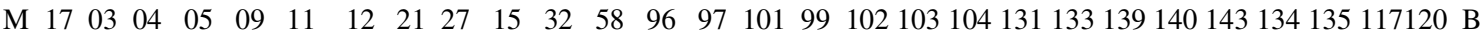

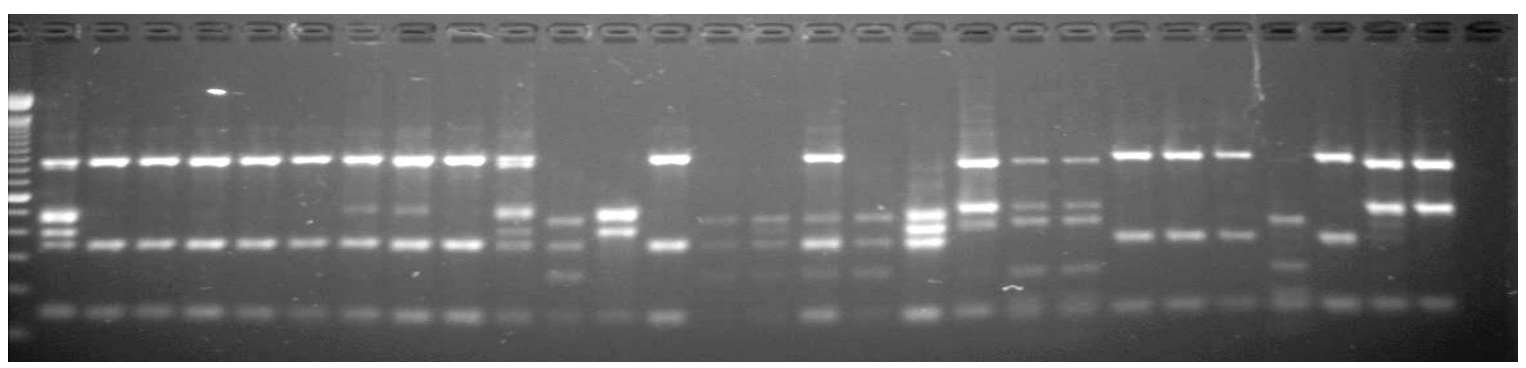

\section{Msp I (b)}

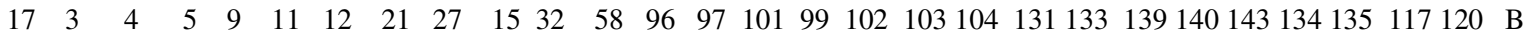

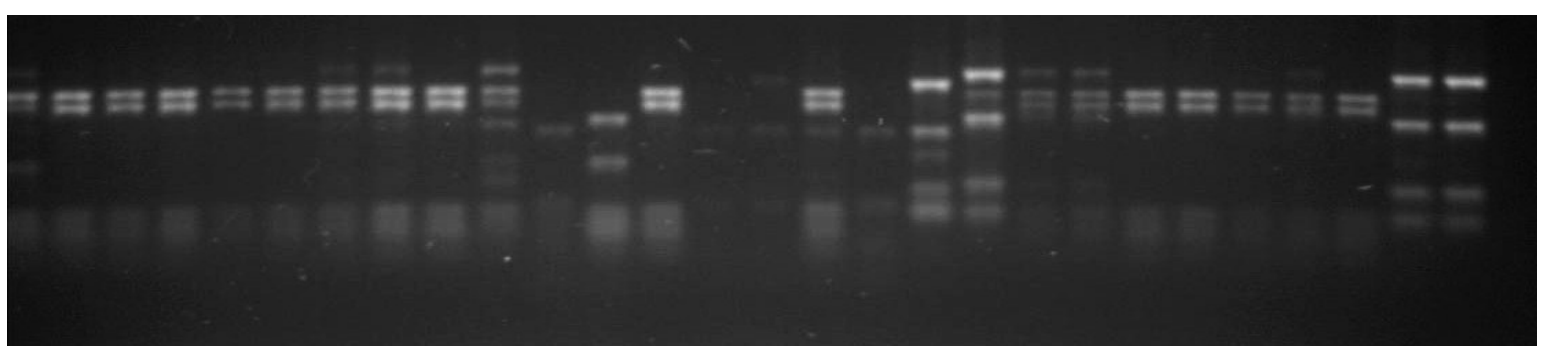

Figura 10. Eletroforese em gel de agarose 1,7\% com produtos de digestão enzimática com as endonucleases $R s a$ I (a) e Msp I (b) após a amplificação do gene 16S rRNA. M marcador molecular $1 \mathrm{~Kb}$ Ladder. B - controle negativo. Os números acima das canaletas correspondem aos isolados de TPA, conforme a numeração da Tabela 2.

Os dados obtidos a partir do ARDRA com as enzimas de restrições (Figura 10) foram combinados. A partir do perfil obtido através da digestão com a enzima Taq I, pôde-se agrupar esses isolados (Tabela 5).

Através dos grupos obtidos com a enzima Taq I, foram selecionados alguns isolados de cada grupo homólogo. Os produtos de PCR foram digeridos então com enzimas de restrição 
Rsa I, Msp I e pôde-se realizar um novo agrupamento desses isolados, confirmando os resultados obtidos com a enzima Taq $\mathrm{I}$.

Tabela 5- Análise de polimorfismo do DNA genômico, através de enzimas de restrição, nos isolados de bactérias de TPA e solo adjacente.

\begin{tabular}{|c|c|}
\hline Isolados homólogos & \% dos grupos homólogos \\
\hline $01 ; 07 ; 17 ; 23$ e 24 & 3,96 \\
\hline 02 & 0,79 \\
\hline $\begin{array}{c}03 ; 04 ; 05 ; 08 ; 09 ; 11 ; 12 ; 13 ; 18 ; 21,27,139,140 \mathrm{e} \\
143\end{array}$ & 11,1 \\
\hline 10 & 0,79 \\
\hline $19 ; 20$ e 25 & 2,38 \\
\hline 22 & 0,79 \\
\hline 26 & 0,79 \\
\hline 29 & 0,79 \\
\hline 30 e 37 & 1,58 \\
\hline $\begin{array}{c}31 ; 32 ; 34 ; 35 ; 38 ; 39 ; 40 ; 41 ; 42 ; 43 ; 46 ; 47 ; 48 ; 49 \\
\quad 50 ; 51 ; 55 ; 57 ; 58 ; 59 ; 60 ; 61 ; 62 ; 63 \text { e } 64\end{array}$ & 19,84 \\
\hline $\begin{array}{c}16 ; 65 ; 67 ; 68 ; 69 ; 70 ; 71 ; 72 ; 73 ; 75 ; 76 ; 78 ; 79 ; 81 ; \\
87 ; 88 ; 91 ; 93 ; 94 ; 98 ; 102\end{array}$ & 16,66 \\
\hline $66 ; 74$ e 77 & 2,38 \\
\hline 86 e 90 & 1,58 \\
\hline $96 ; 97 ; 99$ e 101 & 3,17 \\
\hline $84 ; 107 ; 112 ; 115 ; 116$ e 119 & 4,76 \\
\hline 52 e 100 & 1,58 \\
\hline $103 ; 104 ; 105 ; 109$ e 123 & 3,96 \\
\hline $\begin{array}{c}82 ; 83 ; 85 ; 102 ; 114 ; 118 ; 125 ; 126 ; 128 ; 127 ; 129 \text { e } \\
130\end{array}$ & 9,52 \\
\hline 108 & 0,79 \\
\hline 111 e 122 & 1,58 \\
\hline 117 e 120 & 1,58 \\
\hline 136 & 0,79 \\
\hline 131 e 133 & 1,58 \\
\hline
\end{tabular}

Continua 
Conclusão

\begin{tabular}{cc}
\hline 132 & 0,79 \\
\hline $138 ; 141$ e 142 & 2,38 \\
\hline $89 ; 95 ; 110 ; 134$ e 135 & 3,96 \\
\hline \hline
\end{tabular}

Do total de 143 isolados analisados, 17 isolados ou 11,8\% não amplificaram ou não apresentaram um perfil de restrição. Os resultados obtidos com 126 isolados demonstraram certa diversidade de sequiências de rDNA $16 \mathrm{~S}$ nas amostras analisadas, visto que 6,78\% apresentaram padrões de digestão distintos e houve formação de 3 grandes grupos, os quais apresentaram similaridade nos padrões de restrição.

Uma das maiores dificuldades para se estudar as comunidades do solo é a imensa diversidade genética e fenotípica encontrada nas comunidades bacterianas e de fungos dos solos (OVREAS et al., 1998). É possível que 1\% das bactérias cultiváveis seja representante da população inteira e os outros $99 \%$ está simplesmente em um estado fisiológico que iluda nossa habilidade de as cultivar (RONDON et al., 1999). Entretanto, é também provável que os $99 \%$ são fenotipicamente e geneticamente diferentes do outros $1 \%$ e uma minoria da população está sendo representada (RONDON et al., 1999, 2000).

GARCIA (2006) identificou microrganismos do grupo das actinobactérias em TPAs, apesar da pouca informação sobre a população microbiana do local. Essas bactérias foram determinadas utilizando-se o método ARDRA para obter a diversidade e para identificar/classificar os isolados ao nível de gênero e algumas vezes ao nível de espécie (LOUWS et al., 1999). 
RFLP (Restriction Fragment Length Polymorphism) e ARDRA são métodos utilizados para detectar alterações estruturais nas comunidades microbianas, mas não para medir ou detectar a diversidade de grupos filogenéticos específicos (LIU et al., 1997). Há vários métodos disponíveis para estudar a diversidade microbiana do solo. Cada método tem suas limitações e fornece somente um retrato parcial de um aspecto da diversidade microbiana do solo. É impossível avaliar a eficácia de cada método com o conhecimento atual, recomenda-se que se estudem as populações microbianas nos mais diferentes níveis possíveis (KIRK et al., 2004).

\subsection{Seqüenciamento do gene 16S rRNA}

Após a análise de polimorfismo pelo ARDRA, os 17 isolados foram seqüenciados, sendo editadas as bases de baixa qualidade $(<20)$ através dos programas Phred/Phrap/Consed em sistema operacional Linux e então analisadas pelo BLASTn contra a base de dados do NCBI. Os resultados indicaram a presença de diversos gêneros, como por exemplo, Pseudomonas, Bacillus, Arthrobacter, etc. conforme mostra a Tabela 6. 
Tabela 6- Identificação dos isolados através de seqüenciamento do gene $16 \mathrm{~S}$ rRNA.

\begin{tabular}{lll}
\hline \multicolumn{1}{c}{ Amostra } & \multicolumn{1}{c}{ Espécie } & Homologia \\
& & $(\boldsymbol{\%})$ \\
\hline \hline TP02 & Variovorax paradoxus & $99 \%$ \\
\hline TP11 & Pseudomonas putida & $99 \%$ \\
\hline TP16 & Pseudomonas putida & $99 \%$ \\
\hline TP20 & Agrobacterium sp & $98 \%$ \\
\hline TP26 & Alcaligenes faecalis & $99 \%$ \\
\hline TP30 & Bacillus megaterium & $98 \%$ \\
\hline TP32 & Arthrobacter sp & $97 \%$ \\
\hline TP60 & Arthrobacter sp & $98 \%$ \\
\hline TP65 & Arthrobacter chlorophenolicus & $98 \%$ \\
\hline TP67 & Brevundimonas sp & $99 \%$ \\
\hline TP77 & Arthrobacter chlorophenolicus & $98 \%$ \\
\hline TP86 & Bacillus sp & $98 \%$ \\
\hline TP96 & Pseudomonas putida & $98 \%$ \\
\hline TP103 & Bacillus sp & $99 \%$ \\
\hline TP130 & Bacillus sp & $99 \%$ \\
\hline TP134 & Beta proteobacterium & $99 \%$ \\
\hline TP138 & Arthrobacter chlorophenolicus & $99 \%$ \\
\hline \hline
\end{tabular}

Os índices de similaridade encontrados nas seqüências do 16S rRNA dos diferentes isolados variaram de 97 a 99\% (Tabela 6).

Dos 143 isolados pôde-se diferenciar 8 grupos através dos resultados obtidos pelo seqüenciamento (Tabela 7). 
Tabela 7- População de bactérias encontradas em TPA e solo adjacente.

\begin{tabular}{|c|c|c|c|}
\hline Isolados (TP) & Microrganismo & $\begin{array}{c}\text { Total por } \\
\text { Grupos } \\
\end{array}$ & $\begin{array}{c}\text { Sideróforo } \\
(\%)\end{array}$ \\
\hline 2 & Variovorax sp. & 1 & 100 \\
\hline $\begin{array}{l}3 ; 4 ; 5 ; 8 ; 9 ; 11 ; 12 ; 13 \\
16 ; 18 ; 21 ; 27 ; 43,68 ; 69 \\
70 ; 71 ; 72 ; 73 ; 75 ; 76 ; 78 \\
79 ; 81 ; 87 ; 88 ; 91 ; 93 ; 94 \\
97 ; 98 ; 99 ; 102,139 \text { e } 140\end{array}$ & Pseudomonas sp. & 35 & 49 \\
\hline 19,20 e 25 & Agrobacterium sp. & 3 & 100 \\
\hline 26 & Alcaligenes sp. & 1 & 0 \\
\hline $\begin{array}{l}31 ; 32 ; 34 ; 35 ; 38 ; 39 ; 40 \\
41 ; 42 ; 43 ; 46 ; 47 ; 48 ; 49 \\
50 ; 51 ; 55 ; 57 ; 58 ; 59 ; 60 \\
61 ; 62 ; 63,64,65,77,138 \\
141 \text { e } 142\end{array}$ & Arthrobacter sp. & 30 & 20 \\
\hline 67 & Brevundimonas sp. & 1 & 0 \\
\hline $\begin{array}{l}30,37,86,90,103 ; 104 ; \\
105 ; 109 \text { e } 123 ; 126 ; 127 \\
128 ; 129 \text { e } 130\end{array}$ & Bacillus sp. & 14 & 65 \\
\hline $89 ; 95 ; 110 ; 134$ e 135 & $\begin{array}{l}\text { Beta } \\
\text { proteobacterium }\end{array}$ & 5 & 60 \\
\hline
\end{tabular}

SMITH et al. (2006) realizaram um estudo filogenético de microrganismos bacterianos extraídos de três tipos de solos diferentes da Antártida. Utilizaram o método ARDRA e DGGE (Eletroforese em gel de gradiente desnaturante) e posterior confirmação dos isolados por sequienciamento. Os resultados indicaram uma proporção elevada de isolados não cultiváveis e uma diversidade relativamente baixa de isolados já identificados.

Na Figura 11 observa-se o número total de microrganismos encontrados nas amostras de TPA e solo adjacente, que mostra a grande população de bactérias do gênero Pseudomonas. 


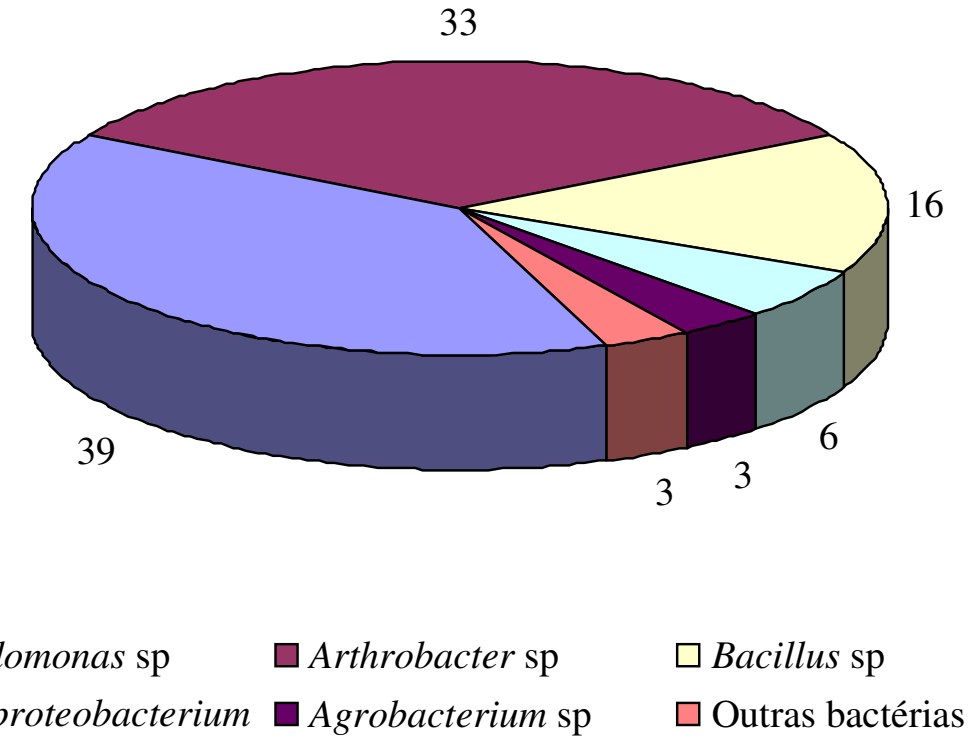

Figura 11. Porcentagem de isolados seqüenciados de solos TPA e adjacente.

Um estudo mais detalhado foi realizado com a linhagem TP11 e TP16 por apresentarem produção de sideróforos e antimicrobianos. Foi realizado o seqüenciamento completo dos dois isolados, onde as linhagens foram identificadas como Pseudomonas putida.

\subsection{Processamento e análise filogenética das seqüências}

A Figura 12 mostra as distâncias genéticas entre os isolados seqüenciados neste estudo e outras seqüências disponíveis no GenBank. A árvore filogenética foi construída com o programa Mega 3 utilizando o 16S rRNA dos isolados seqüenciados. 


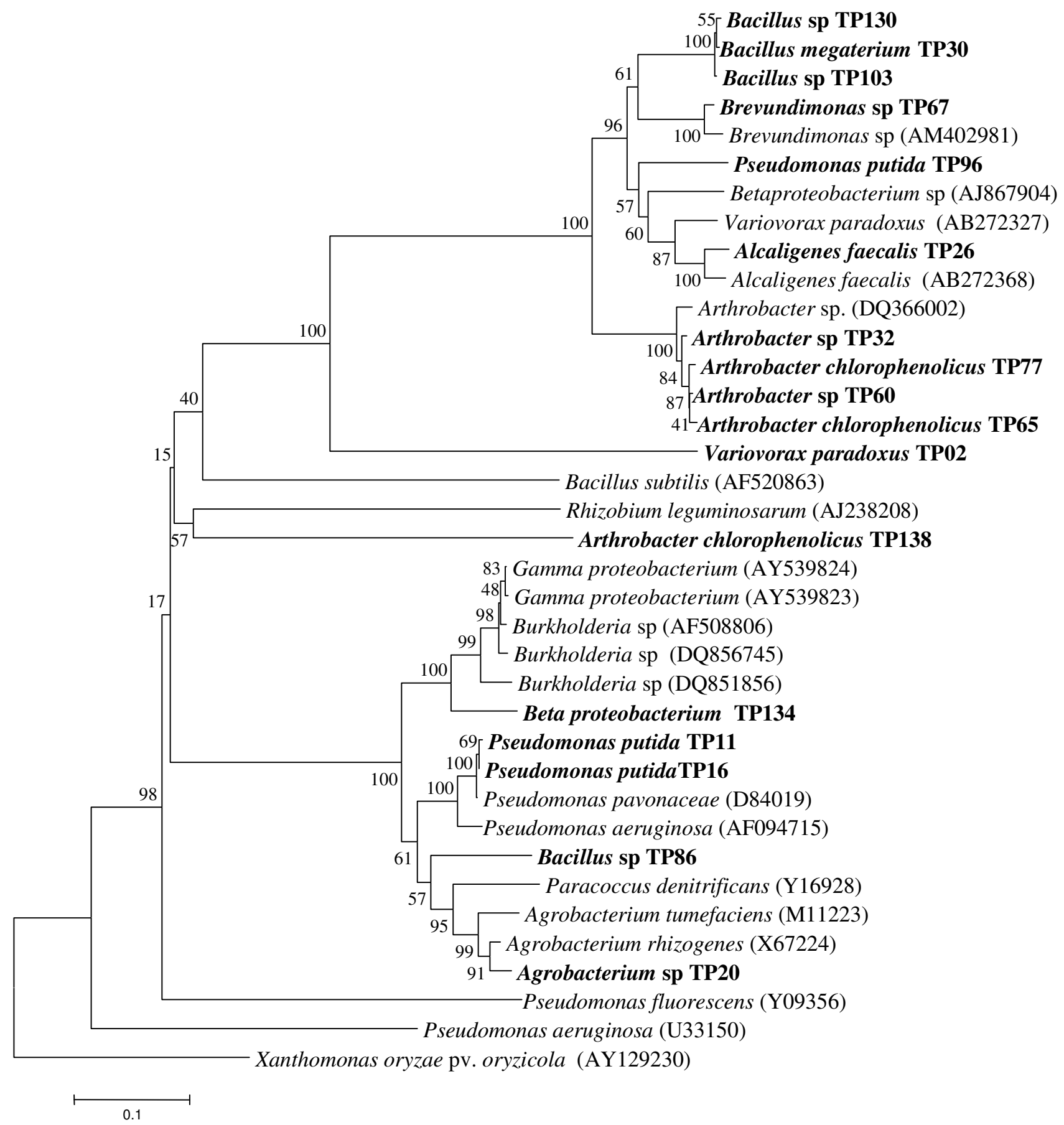

Figura 12. Árvore filogenética baseada na seqüência do gene $16 \mathrm{~S}$ rRNA de isolados de TPA e solo adjacente, construída pelo método de "Neighbour Joining". A árvore foi enraizada utilizando o gene 16S rRNA de Xanthomonas oryzae pv. oryzicola como grupo externo. Os números acima das linhas são valores de reamostragem obtidos com 1000 replicações. 
Numa análise de reamostragem para 1000 replicações observou-se a formação de 2 grandes grupos: um grupo formado principalmente pelas bactérias Arthrobacter, Alcaligenes e Bacillus e outro grupo formado pelas Burkholderia, Pseudomonas e Agrobacterium. Os resultados obtidos neste estudo comprovaram que as 2 linhagens selecionadas para o seqüenciamento completo (TP11 e TP16) estão relacionadas entre si e com outras Pseudomonas sob o ponto de vista filogenético. Todas as linhagens selecionadas do GenBank para compor a árvore filogenética foram escolhidas baseadas na sua capacidade de produzir sideróforos.

\subsection{Distribuição dos genes que codificam para NRPS e PKS}

O produto dessas complexas vias possuem várias propriedades farmacológicas, incluindo antibióticos, anti-tumor, anti-fúngico e agentes imunosupressores (JENKEKODAMA et al., 2005). A Tabela 8 apresenta a distribuição dos genes que codificam para NRPS e PKS de todos os isolados testados através da amplificação por PCR e o resultado da produção de sideróforo através de bioensaios com meio de cultivo seletivo (SCHWYN; NEILANDS, 1987). 
Tabela 8- Identificação dos isolados que apresentaram os genes que codificam para NRPS e PKS e produção de sideróforos.

\begin{tabular}{|c|c|c|c|}
\hline Isolado & NRPS & PKS & Sideróforo \\
\hline TP01 & - & - & + \\
\hline TP02 & - & - & + \\
\hline TP03 & + & - & + \\
\hline ТP04 & + & - & + \\
\hline TP05 & + & - & + \\
\hline ТР06 & - & - & + \\
\hline TP07 & - & - & + \\
\hline TP08 & - & - & + \\
\hline TP09 & - & + & + \\
\hline TP10 & + & + & + \\
\hline TP11 & - & + & + \\
\hline TP12 & - & - & + \\
\hline TP13 & + & - & + \\
\hline TP14 & - & + & + \\
\hline TP15 & - & + & + \\
\hline TP16 & + & - & + \\
\hline TP17 & - & + & + \\
\hline TP18 & + & + & + \\
\hline TP19 & - & - & + \\
\hline TP20 & - & - & + \\
\hline TP21 & - & + & + \\
\hline TP22 & - & - & + \\
\hline TP23 & - & - & + \\
\hline TP24 & - & - & + \\
\hline TP25 & - & + & + \\
\hline TP26 & - & + & - \\
\hline TP27 & - & - & - \\
\hline TP28 & - & - & - \\
\hline TP29 & - & + & - \\
\hline TP30 & - & - & - \\
\hline TP31 & - & - & + \\
\hline TP32 & - & - & - \\
\hline TP33 & - & - & - \\
\hline TP34 & - & - & - \\
\hline TP35 & - & - & $\begin{array}{c}- \\
\text { Continua }\end{array}$ \\
\hline
\end{tabular}




\begin{tabular}{|c|c|c|c|}
\hline TP36 & - & - & - \\
\hline TP37 & - & - & - \\
\hline TP38 & - & - & - \\
\hline TP39 & - & + & - \\
\hline ТP40 & - & - & + \\
\hline TP41 & - & - & - \\
\hline TP42 & - & - & - \\
\hline TP43 & - & + & - \\
\hline TP44 & - & - & - \\
\hline TP45 & - & - & - \\
\hline TP46 & - & - & - \\
\hline TP47 & - & - & - \\
\hline TP48 & - & - & - \\
\hline TP49 & - & - & - \\
\hline TP50 & - & + & - \\
\hline TP51 & - & - & - \\
\hline TP52 & + & - & - \\
\hline TP53 & - & - & - \\
\hline TP54 & + & - & - \\
\hline TP55 & + & - & - \\
\hline TP56 & - & - & - \\
\hline TP57 & - & - & - \\
\hline TP58 & - & - & + \\
\hline TP59 & - & - & - \\
\hline ТP60 & - & - & - \\
\hline TP61 & - & - & - \\
\hline ТР62 & - & - & - \\
\hline TP63 & - & - & - \\
\hline TP64 & - & - & - \\
\hline TP65 & - & - & - \\
\hline ТР66 & - & - & - \\
\hline ТР67 & - & - & - \\
\hline TP68 & - & - & - \\
\hline ТP69 & - & - & - \\
\hline TP70 & - & - & + \\
\hline TP71 & - & - & - \\
\hline TP72 & - & - & - \\
\hline TP73 & - & - & - \\
\hline
\end{tabular}

Continua 


\begin{tabular}{|c|c|c|c|}
\hline TP74 & - & - & - \\
\hline TP75 & - & - & - \\
\hline TP76 & - & - & - \\
\hline TP77 & - & - & - \\
\hline TP78 & - & - & - \\
\hline TP79 & - & - & - \\
\hline TP80 & - & - & - \\
\hline TP81 & - & - & - \\
\hline TP82 & - & - & - \\
\hline TP83 & + & + & - \\
\hline TP84 & - & - & - \\
\hline TP85 & - & - & - \\
\hline TP86 & + & - & - \\
\hline TP87 & + & - & - \\
\hline TP88 & - & - & - \\
\hline TP89 & - & - & - \\
\hline TP90 & + & - & - \\
\hline TP91 & - & - & - \\
\hline TP92 & - & - & - \\
\hline ТP93 & - & - & - \\
\hline TP94 & - & - & - \\
\hline TP95 & - & - & - \\
\hline ТР96 & + & - & + \\
\hline TP97 & - & - & + \\
\hline TP98 & - & - & + \\
\hline TP99 & - & - & + \\
\hline TP100 & - & - & + \\
\hline TP101 & - & - & + \\
\hline TP102 & - & - & + \\
\hline TP103 & - & - & + \\
\hline TP104 & + & - & + \\
\hline TP105 & - & - & + \\
\hline TP106 & - & - & + \\
\hline TP107 & - & - & + \\
\hline TP108 & - & + & + \\
\hline TP109 & - & - & + \\
\hline TP110 & - & - & + \\
\hline TP111 & - & - & + \\
\hline
\end{tabular}

Continua 
Conclusão

\begin{tabular}{|c|c|c|c|}
\hline TP112 & + & - & + \\
\hline TP113 & - & - & + \\
\hline TP114 & - & - & + \\
\hline TP115 & + & + & + \\
\hline TP116 & + & + & + \\
\hline TP117 & - & - & + \\
\hline TP118 & + & + & - \\
\hline TP119 & + & + & + \\
\hline TP120 & + & + & + \\
\hline TP121 & - & + & + \\
\hline TP122 & - & + & - \\
\hline TP123 & - & - & - \\
\hline TP124 & - & - & - \\
\hline TP125 & - & - & - \\
\hline TP126 & - & - & + \\
\hline TP127 & + & + & + \\
\hline TP128 & + & + & + \\
\hline TP129 & - & - & + \\
\hline TP130 & - & + & + \\
\hline TP131 & - & - & + \\
\hline TP132 & - & + & + \\
\hline TP133 & - & - & + \\
\hline TP134 & - & + & + \\
\hline TP135 & + & - & + \\
\hline TP136 & - & + & + \\
\hline TP137 & - & - & + \\
\hline TP138 & - & - & + \\
\hline TP139 & - & - & + \\
\hline TP140 & - & - & + \\
\hline TP141 & - & - & + \\
\hline TP142 & - & - & + \\
\hline TP143 & - & + & + \\
\hline
\end{tabular}

Os dados indicam que $50 \%$ dos isolados apresentaram produção de sideróforos, porém 57\% deste total não apresentaram os genes de NRPS e PKS, sugerindo que a via de produção 
da molécula seja ribossomal. Dos 143 isolados $10 \%$ apresentaram o gene que codifica para NRPS, 14\% para o gene que codifica para PKS e 7\% possuem os 2 genes. 


\section{NRPS (A)}

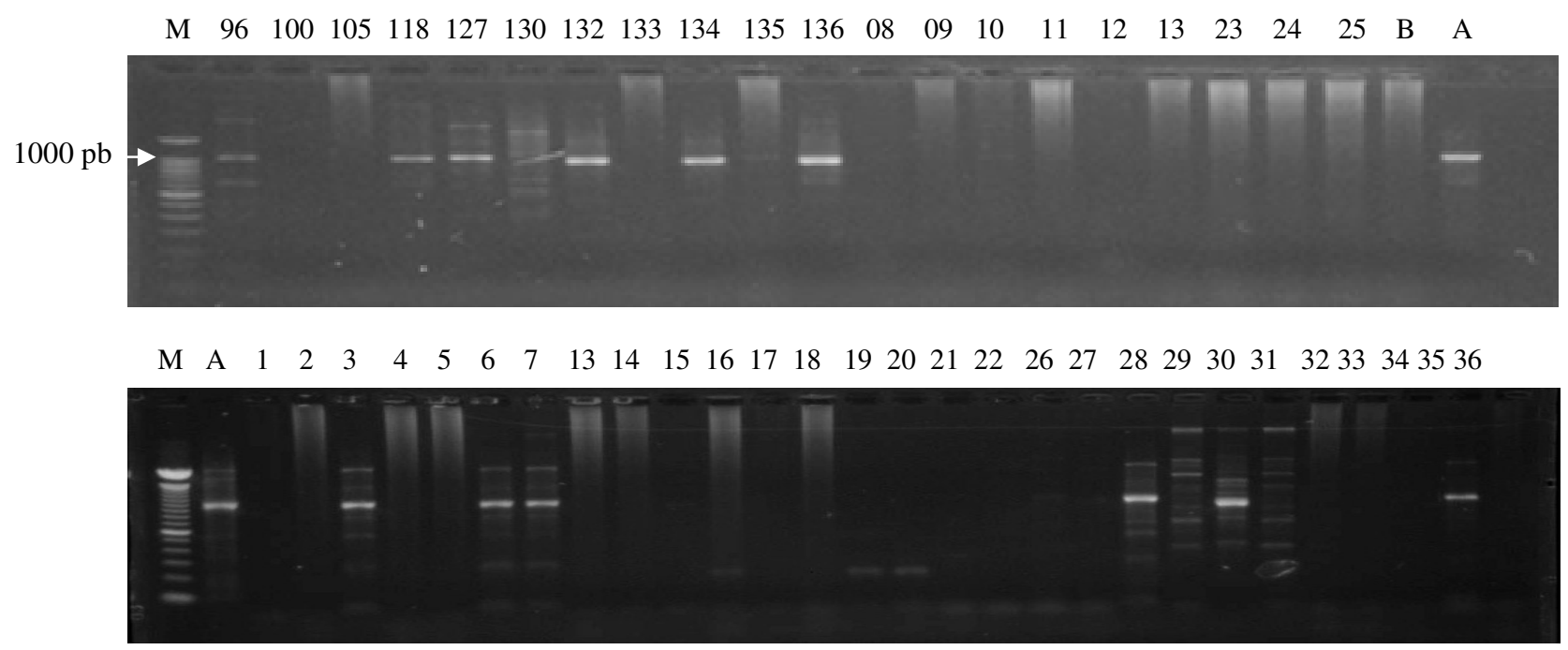

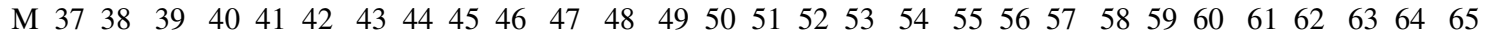

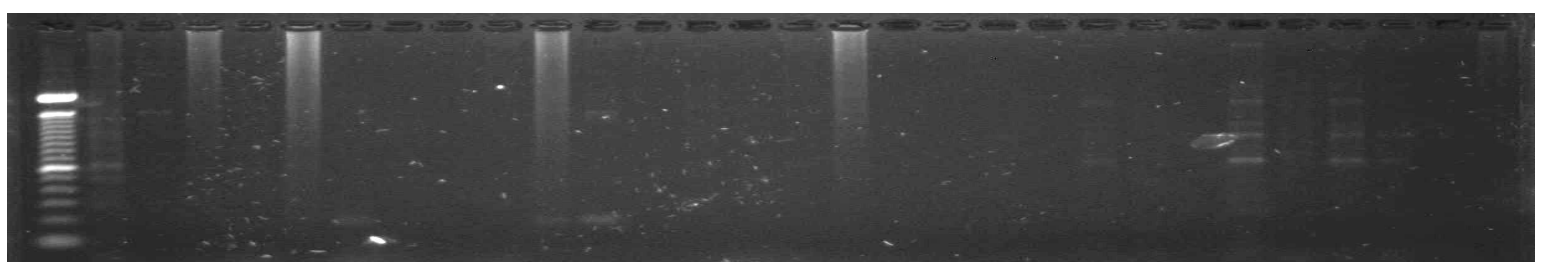

$\begin{array}{llllllllllllllllll}\text { M } & 66 & 67 & 68 & 69 & 70 & 71 & 72 & 73 & 74 & 75 & 76 & 77 & 78 & 79 & 80 & 81 & \text { B }\end{array}$

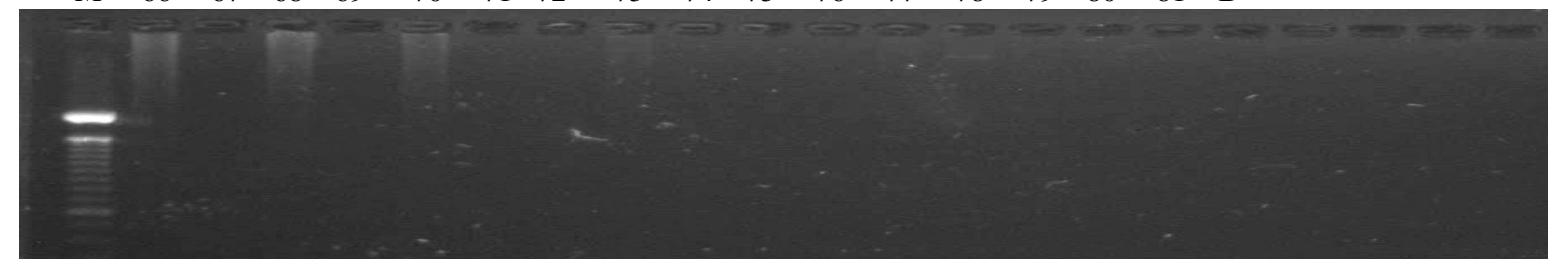

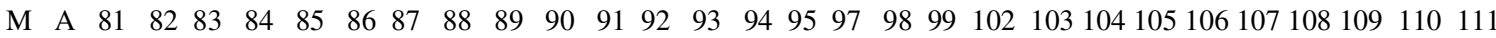

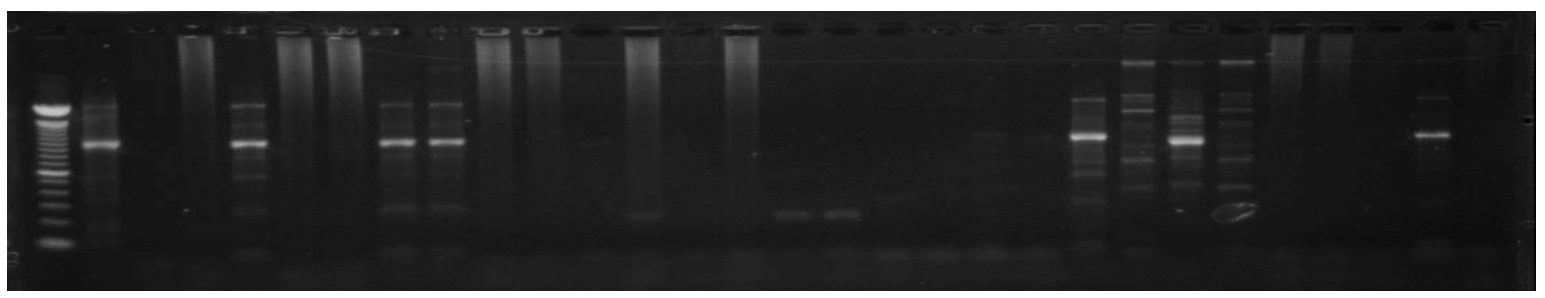

M A 112113114115116117119120121122123124125126128129131137138139140141142143 B

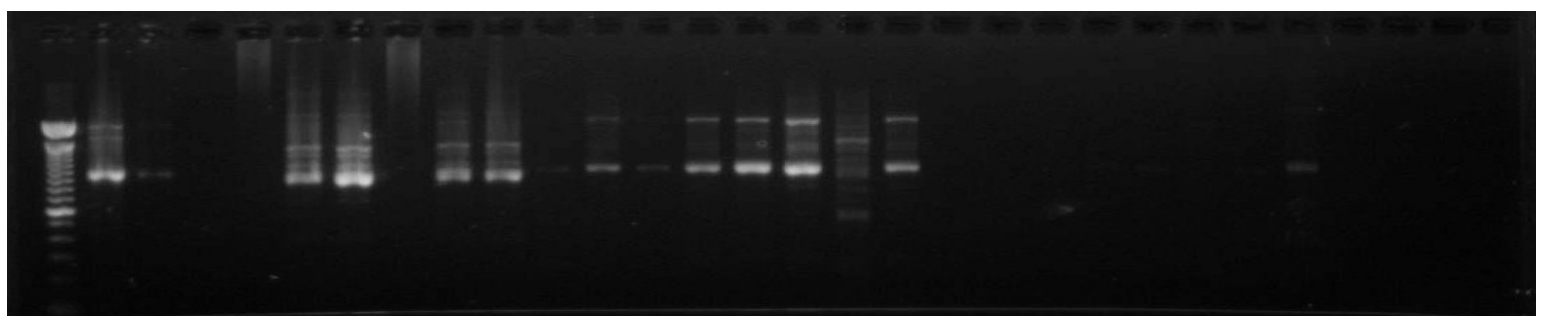




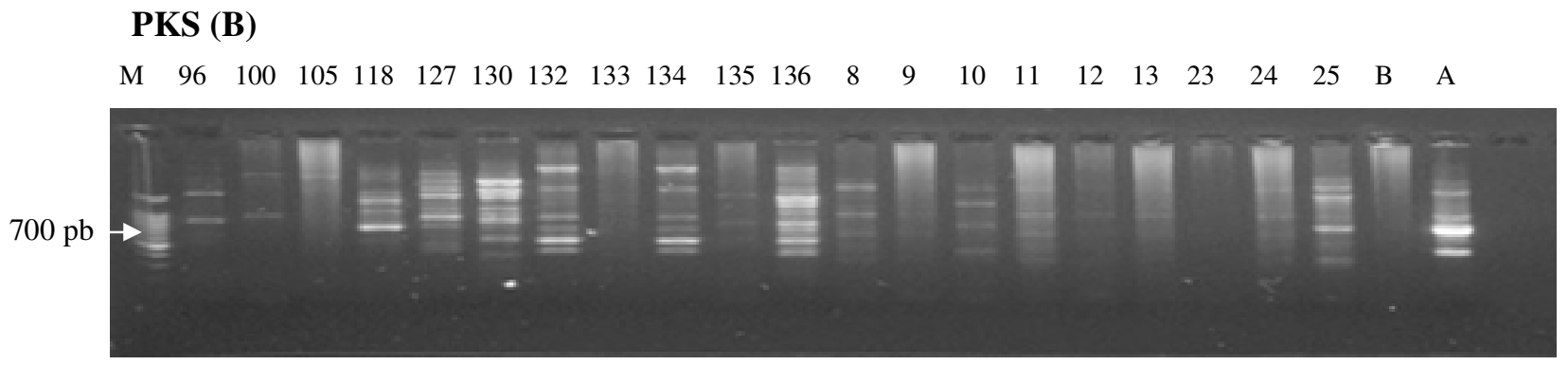

$\begin{array}{llllllllllllllllllllllllllllll}\mathrm{M} & \mathrm{A} & 1 & 2 & 3 & 4 & 5 & 6 & 7 & 13 & 14 & 15 & 16 & 17 & 18 & 19 & 20 & 21 & 22 & 26 & 27 & 28 & 29 & 30 & 31 & 32 & 33 & 34 & 35 & 36\end{array}$

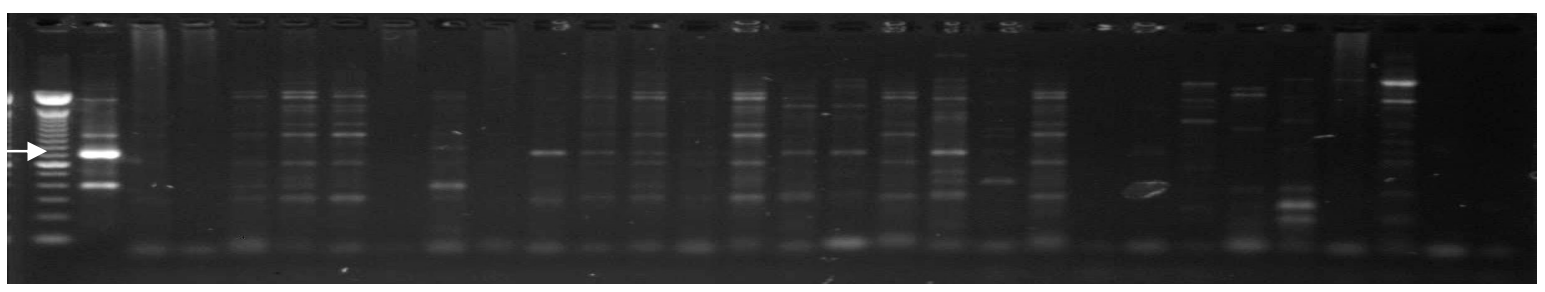

M $37 \begin{array}{llllllllllllllllllllllllllll}38 & 39 & 40 & 41 & 42 & 43 & 44 & 45 & 46 & 47 & 48 & 49 & 50 & 51 & 52 & 53 & 54 & 55 & 56 & 57 & 58 & 59 & 60 & 61 & 62 & 63 & 64 & 65\end{array}$
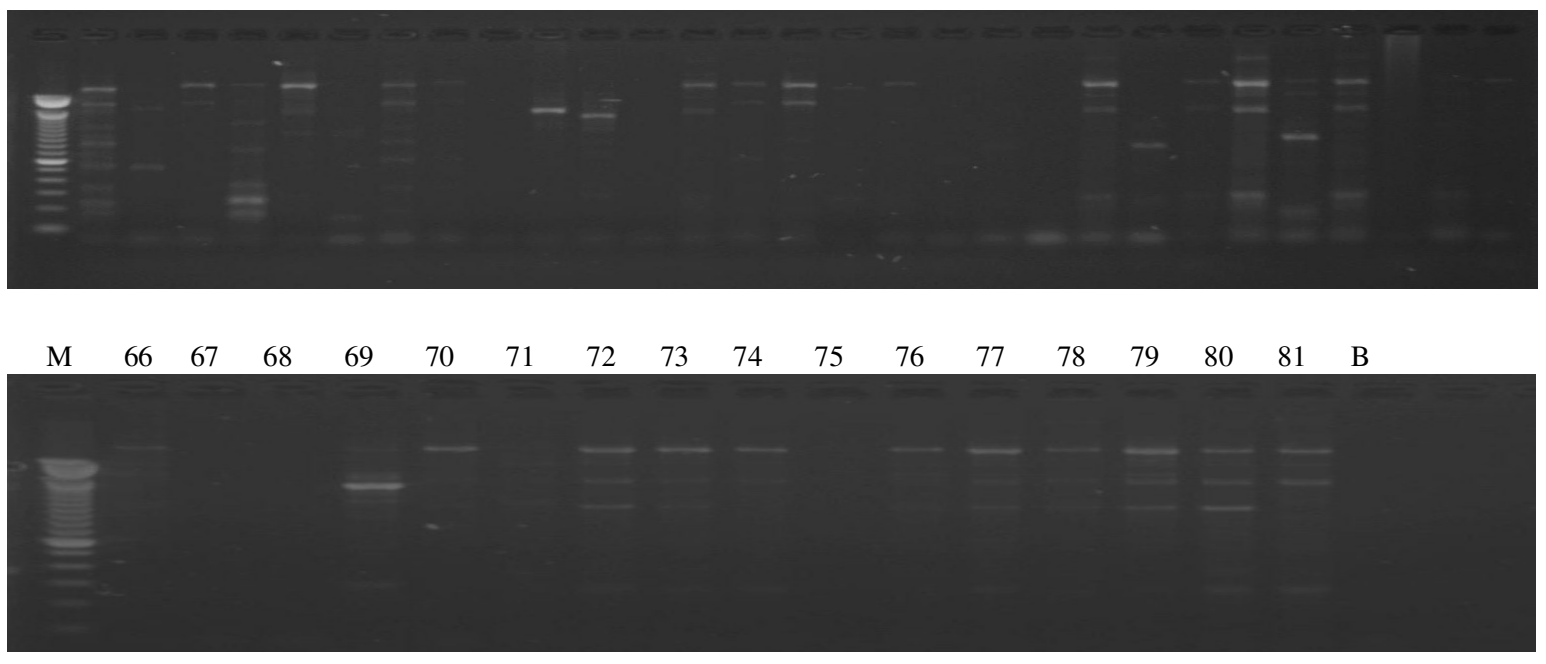

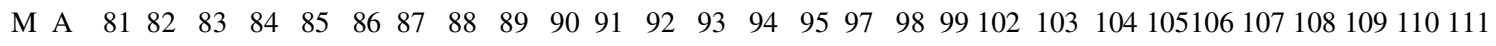

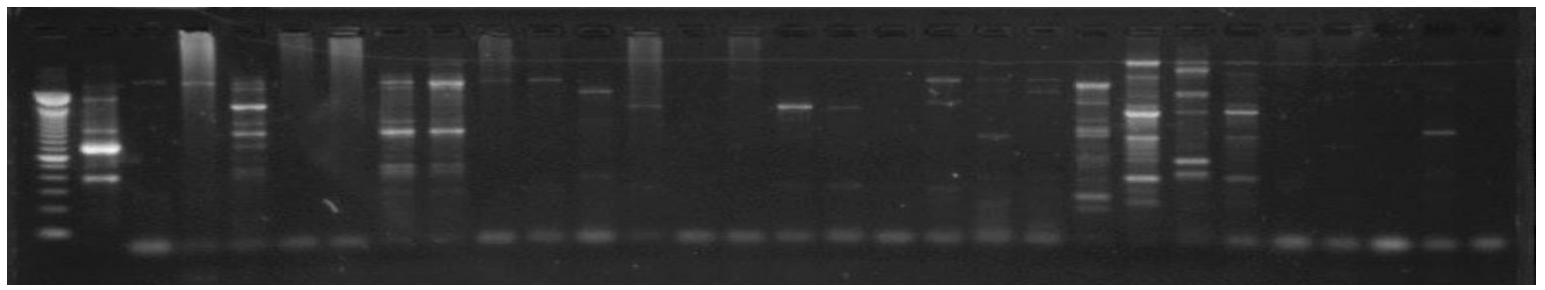

M A 112113114115116117119120121122123124125126128129131137138139140141142143 B

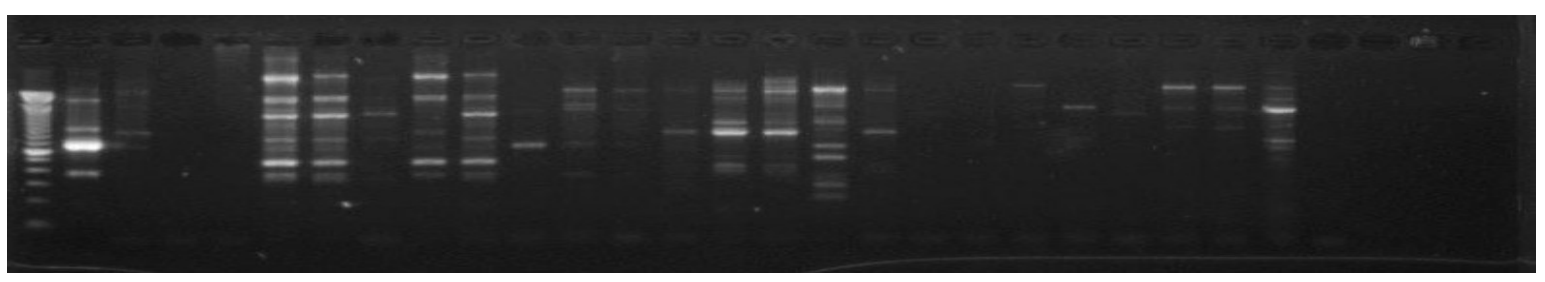

Figura 13. Produtos amplificados para o gene NRPS (A) e PKS (B). M) Marcador Ladder 100 pb DNA; B) Controle negativo (sem DNA); A) Controle positivo (Fischerella sp CENA19). Os números acima das canaletas correspondem às amostras indicadas na Tabela 2. 
A Figura 14 apresenta a diversidade das bactérias presentes em TPA e solos adjacente em relação a presença dos genes que codificam para as enzimas NRPS e PKS. Observa-se que a maioria das bactérias não apresentou esses genes. Isto sugere que a biossíntese desses compostos possa ser por outra via, tal como a ribossomal, ou também devido a não otimização da PCR.

A

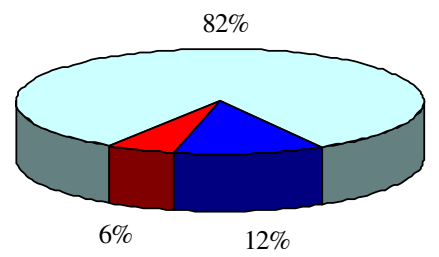

B

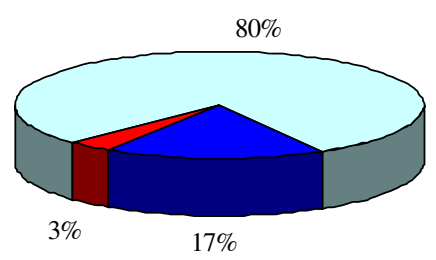

Figura 14. Distribuição de genes que codificam para NRPS e PKS dos isolados de TPA e solo adjacente. A) NRPS; B) PKS. Isolados que não apresentaram os genes $\square$ ). Isolados de TPA que apresentaram os genes $(\square)$. Isolados de solo adjacente que apresentaram os genes $(\square)$.

A Tabela 9 apresenta a distribuição das linhagens de acordo com a profundidade de onde foram isoladas das amostras dos solos em relação à produção de sideróforos e presença dos genes NRPS e PKS.

Tabela 9- Distribuição dos isolados (\%) em diferentes profundidades (cm) em TPA e solo adjacente de acordo com a produção de sideróforos e presença de NRPS e PKS.

\begin{tabular}{|l|c|c|c|c|c|c|c|c|c|}
\cline { 2 - 11 } \multicolumn{1}{c|}{} & \multicolumn{4}{c}{ TPA } & \multicolumn{4}{c|}{ Solo adjacente } \\
\cline { 2 - 10 } \multicolumn{1}{c|}{} & $\mathbf{1 0}$ & $\mathbf{0 - 1 \mathbf { 1 8 } ^ { \mathbf { a } }}$ & $\mathbf{1 5}$ & $\mathbf{3 0}$ & $\mathbf{4 5}$ & $\mathbf{0 - 1 0}$ & $\mathbf{1 0}-\mathbf{2 0}$ & $\mathbf{1 0}$ & $\mathbf{2 0}$ \\
\hline Sideróforo & 100 & 100 & 7 & 25 & 10 & 80 & 100 & 88 & 100 \\
\hline OS & 0 & 0 & 7 & 25 & 13 & 13 & 45 & 25 & 11 \\
\hline PKS & 0 & 0 & 15 & 0 & 2,5 & 46 & 27 & 37 & 22 \\
\hline $\begin{array}{l}\text { Total de } \\
\text { isolados }\end{array}$ & 1 & 1 & 27 & 4 & 40 & 15 & 11 & 35 & 4 \\
\hline
\end{tabular}

${ }^{\text {a }}$ Isolados de Rio Preto da Eva, AM. Os demais são derivados do Município de Presidente Figueiredo. 
De acordo com os resultados apresentados na Tabela 9, pôde-se observar que a produção de sideróforos foi detectada nas populações principalmente das amostras de solos adjacentes, já que houve uma representação maior dos isolados nestes solos.

\subsection{Produção de sideróforos em meio sólido}

A produção de sideróforos foi verificada cultivando os isolados em meio de cultura sem a presença de ferro. Os resultados mostraram que as linhagens analisadas foram capazes de crescer nestas condições (livre de ferro), sem inibição do crescimento (Figura 15). A reação positiva para sideróforo pelo método do CAS mostra a presença de um halo amarelo ao redor das colônias (SCHWYN; NEILANDS, 1987).

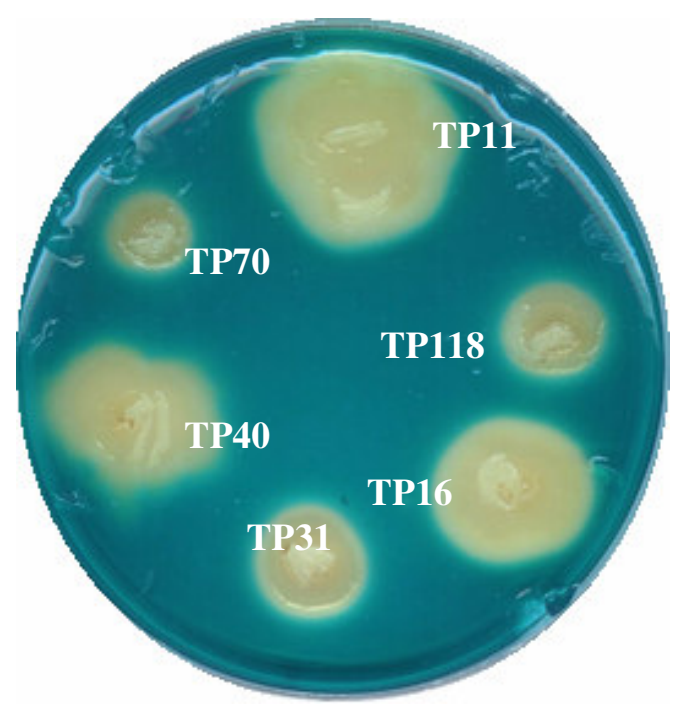

Figura 15. Crescimento das linhagens TP11, TP118, TP16, TP31, TP40 e TP70 em meio de cultivo contendo o complexo CAS, mostrando a formação de halos ao redor das colônias, indicando reação positiva para a produção de sideróforos.

Dos 143 isolados estudados, 72 apresentaram halos ao redor das colônias, as quais indicaram produção de sideróforos como descrito na Tabela 8. O tempo para a produção do 
halo foi diferente para cada colônia, apresentando halos entre 5 a 10 dias depois de inoculados em meio CAS.

RAJKUMAR et al. (2006) observou a produção de sideróforos e ácido acético indol (IAA) pelos isolados Pseudomonas sp. PsA4 e Bacillus sp. Ba32 em solos com diferentes concentrações de cromo, indicando que esses metabólitos protegem a planta contra os efeitos inibitórios do cromo, estimulando seu crescimento.

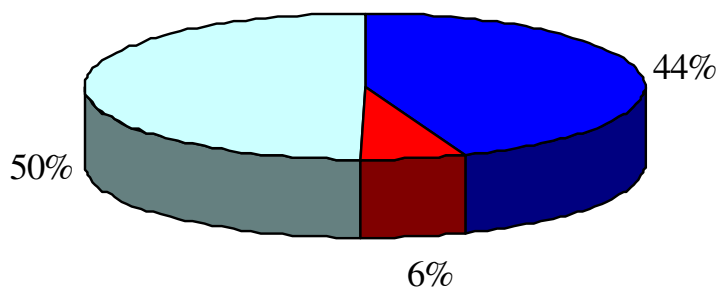

Figura 16. Produção de sideróforos (CAS-agar) de isolados de TPA e solo adjacente. Isolados que não formaram halos $(\square)$. Isolados de TPA que formaram halos ( $\square$ ). Isolados de solo adjacente que formaram halos ( $\square)$.

A Figura 16 indica a porcentagem de isolados que apresentaram produção de sideróforos (50\%). O estudo molecular indicou que a maioria dos isolados que foram positivos para a presença dos genes NRPS e PKS encontra-se em solo adjacente, o mesmo ocorrendo com o estudo bioquímico (CAS). A não produção de sideróforos dos outros $50 \%$ de isolados pode ser explicada pelo fato de que muitos dos microrganismos não expressaram os genes ou não se adaptaram ao meio de cultivo usado especialmente para estes testes, ou mesmo por problemas de otimização de cultivo. 


\subsection{Análise pelos métodos bioquímicos de Csácky e Arnow}

O teste de Csácky foi usado para a detecção de sideróforos do tipo hidroxamato enquanto que o teste de Arnow para a detecção de sideróforos do tipo catecol diretamente do sobrenadante da cultura de células cultivadas em meio MM9 sem ferro. A quantidade destas biomoléculas sintetizadas em condições de baixo ferro são apresentadas na Tabela 10.

Tabela 10- Produção de sideróforos do tipo catecol e hidroxamato pelos isolados de TPA e solo ajdacente.

\begin{tabular}{|c|c|c|}
\hline Isolado & $\begin{array}{c}\text { ácido benzóico equivalente }(\mu \mathrm{M}) \\
\text { (catecol) }\end{array}$ & $\begin{array}{c}\text { Hidroxilamina equivalente }(\mu \mathrm{M}) \\
\text { (hidroxamato) }\end{array}$ \\
\hline TP01 & 0 & 3,8 \\
\hline TP02 & 0 & 4,4 \\
\hline TP03 & 0 & 12,3 \\
\hline TP04 & 0 & 7,3 \\
\hline TP05 & 0 & 1,6 \\
\hline TP06 & 0 & 5,8 \\
\hline TP09 & 0 & 7,6 \\
\hline TP10 & 0 & 26,9 \\
\hline TP11 & 0 & 0 \\
\hline TP12 & 0 & 18,9 \\
\hline TP15 & 45,5 & 32,7 \\
\hline TP16 & 107,6 & 25,2 \\
\hline TP17 & 0 & 18,5 \\
\hline TP20 & 63,4 & 0 \\
\hline TP21 & 0 & 7,4 \\
\hline TP22 & 19 & 0 \\
\hline TP26 & 0 & 0 \\
\hline TP27 & 0 & 0 \\
\hline TP108 & 0 & 0 \\
\hline TP110 & 0 & 0 \\
\hline TP114 & 0 & 0 \\
\hline TP120 & 0 & 0 \\
\hline TP122 & 0 & 0 \\
\hline TP130 & 0 & 47,7 \\
\hline TP131 & 0 & 37,9 \\
\hline TP132 & 0 & 0 \\
\hline TP133 & 0 & 91,1 \\
\hline TP134 & 0 & 0 \\
\hline TP135 & 0 & 23,8 \\
\hline TP136 & 0 & 38,8 \\
\hline TP138 & 0 & 20,7 \\
\hline
\end{tabular}


Conclusão

\begin{tabular}{cll}
\hline TP139 & 0 & 90,9 \\
\hline TP140 & 0 & 63,0 \\
\hline TP141 & 0 & 28,5 \\
\hline TP143 & 0 & 40,1 \\
\hline \hline
\end{tabular}

As linhagens TP16 e TP20 foram as que produziram sideróforos do tipo catecol em maior quantidade, enquanto que a TP15 e TP22 foram as que menos produziram este composto. Baseado no teste de catecol e hidroxamato, as linhagens podem ser classificadas em três categorias: o primeiro grupo inclui aquelas que produzem elevada quantidade de sideróforo; o segundo grupo consiste de linhagens que produzem baixa concentração do composto; e o terceiro grupo formado por linhagens que não apresentaram nenhuma produção de sideróforo.

NAIK e SAKTHIVEL (2006) detectaram e caracterizaram sideróforos produzidos por um novo isolado chamado PVP6 do gênero das Pseudomonas sp usando o teste $\mathrm{FeCL}_{3}$ e o teste cromo azurol. A identificação das classes hidroxamato, fenolato e carboxila foram realizadas através do teste Arnow. Os resultados indicaram a presença dos sideróforos.

\subsection{Estudo da linhagem Pseudomonas putidaTP11}

Os espectros de massas das amostras de $P$. putida TP11 foram obtidos por inserção direta no equipamento. O espectro foi obtido na faixa de 100 a $2000 \mathrm{Da}$ (Figura 17 A e B) e apresenta o íon molecular $[\mathrm{M}+\mathrm{H}]^{+} 697$, o qual é o único íon que difere do controle (meio de cultura MM9 extraído em acetato de etila). 


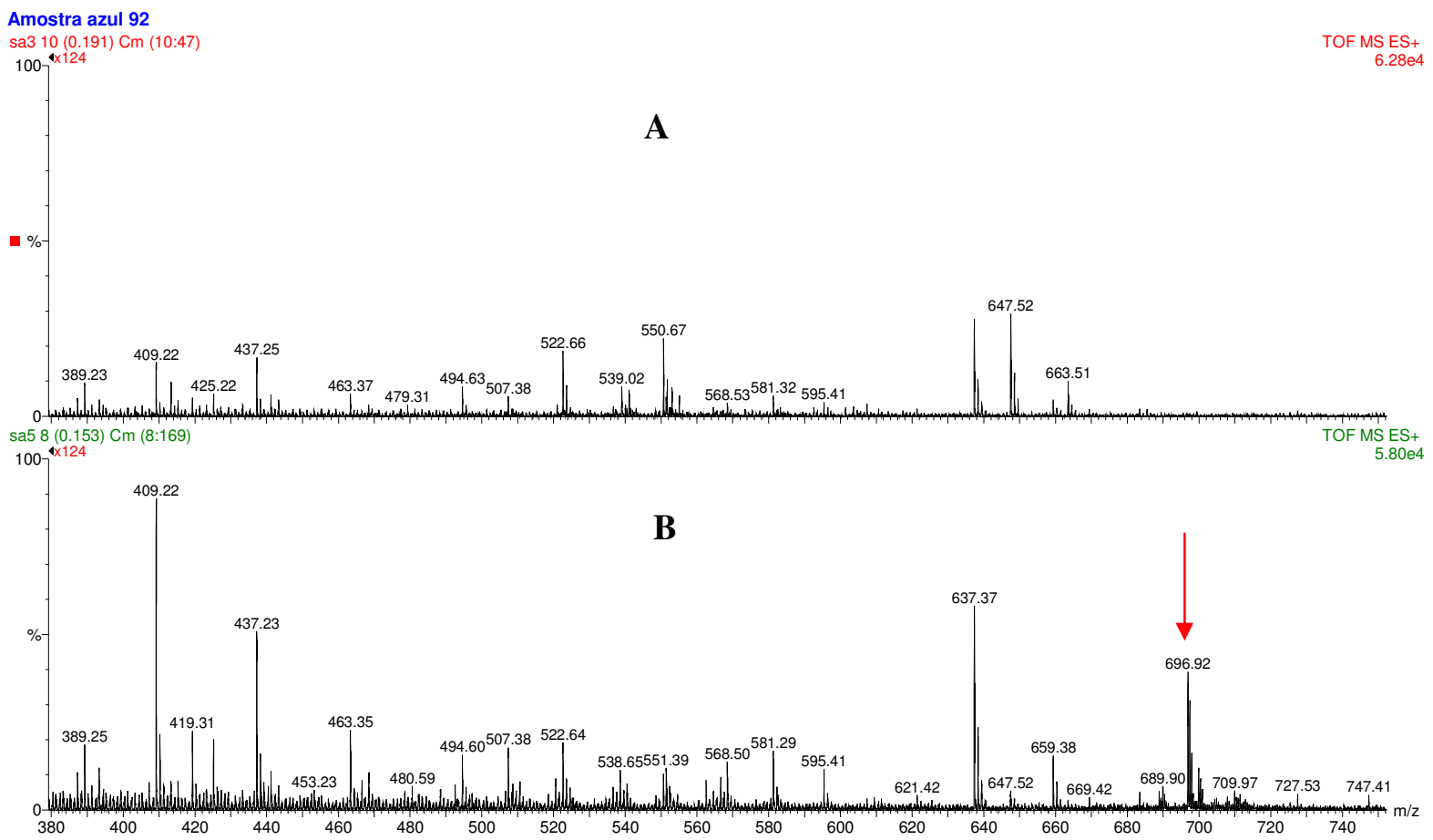

Figura 17. Espectros de massas em modo positivo de ionização por "electrospray" (ESI). A) Amostra de $P$. putida TP11 (região de formação de halo) ( $\mathrm{m} / \mathrm{z}$ 697); B) Amostra do controle (sem formação de halo).

A fragmentação do íon 697 foi realizada para a elucidação estrutural da molécula encontrada, possivelmente um sideróforo, já que as análises determinaram a produção deste composto por este isolado, porém através da análise de Csácky e Arnow não foi possível determinar a que classe ele pertence. A fragmentação resultou em 3 fragmentos identificados como sendo a eliminação dos aminoácidos histidina (155 Da, MM do resíduo), valina (99 Da, massa molecular do resíduo) e alanina (71 Da, MM do resíduo). No mesmo espectro ainda pode-se observar o íon imônio para leucina/isoleucina $(\mathrm{m} / \mathrm{z} 86)$ (Figura 18$)$.

Mesmo com a fragmentação obtida por MS/MS não foi possível identificar o tipo de sideróforo produzido por este isolado, porém a presença do aduto de ferro sugere que esta molécula seja um quelante. 


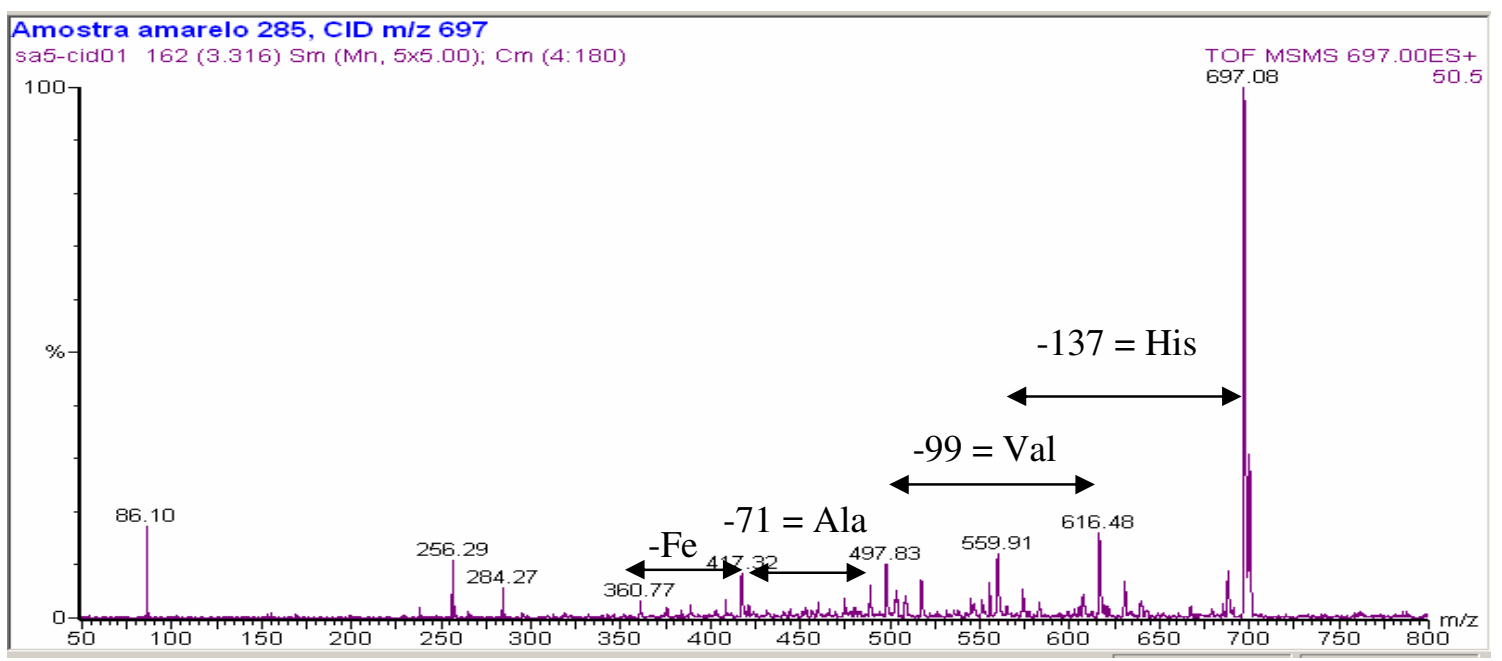

Figura 18. Espectros MS/MS de dissociação induzida por colisão (CID) do composto com $m / z 697$ da amostra de P. putida TP11 (região de formação de halo).

\subsection{Estudo da linhagem Pseudomonas putida TP16}

Um estudo mais aprofundado foi realizado com a linhagem TP16, por apresentar concentrações significativas de sideróforos dos tipos catecol e hidroxamato. Ensaios de bioatividade e de produção de sideróforos foram realizados e a biomolécula foi identificada. 


\subsubsection{Ensaio de Bioatividade}

Para este estudo, os resultados apresentados na Figura 19 mostram a capacidade dos solventes escolhidos (acetato de etila e clorofórmio) de extraírem os metabólitos antibacterianos.

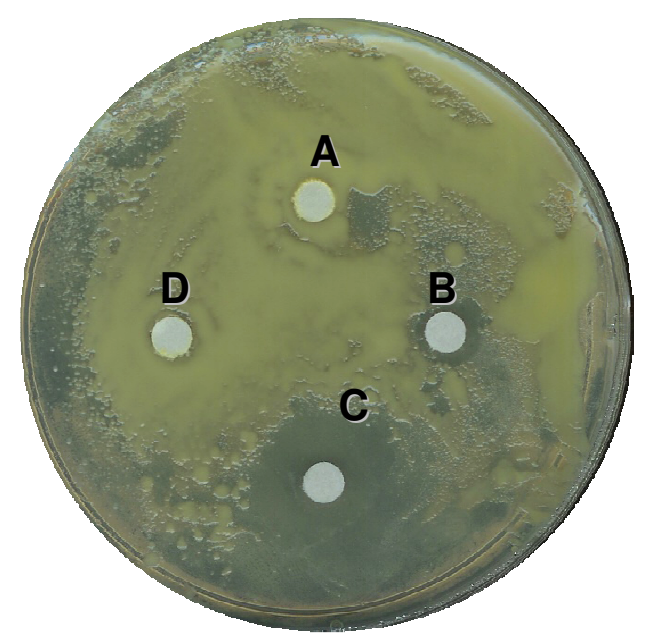

Figura 19. Teste de bioensaio. A) Meio MM9 extraído em clorofórmio; B) Meio MM9 extraído em acetato de etila; C) Sobrenadante de $P$. putida TP16 extraído em clorofórmio; D) Sobrenadante de P. putida TP16 extraído em acetato de etila. Microrganismo teste $=$ Micrococcus luteus .

Clorofórmio em comparação com acetato de etila foi o melhor solvente para extração dos compostos.

Os extratos obtidos com as extrações dos meios de cultura foram usados para a determinação qualitativa quanto à habilidade dos metabólitos extraídos de inibir o crescimento bacteriano de Micrococcus luteus.

Como pode ser observado na figura acima, o extrato em clorofórmio apresentou uma forte atividade contra o microrganismo teste. Esses resultados positivos levaram a um estudo mais profundo dos compostos químicos produzidos por este isolado. 
Um grande número de métodos químicos e biológicos tem sido desenvolvido e são muito efetivos na determinação de muitos antibióticos. Um exemplo disso é a bacitracina, a qual tem sido detectada por vários métodos, incluindo testes de bioatividade (SIN; WONG, 2003), teste por ELISA (Enzyme-linked immunosorbent assay) (BEIER; STANKER, 1996) e até uso de enzimas como a fosfatase (WILLIAMS et al., 1994) e peroxidase de nabo ("horseradish") (MATSUMOTO et al., 1997). Métodos químicos incluem cromatografia em camada delgada, cromatografia líquida de alta resolução, eletroforese capilar, métodos colorimétricos e mais recentemente cromatografia líquida acoplada a espectrometria de massas (SIN; WONG, 2003; SIN et al., 2005). Como demonstrado por PAVLI e SOKOLIC (1990) resultados obtidos por HPLC não foram consistentes com os testes de bioatividade, já que a análise por HPLC quantificou apenas bacitracina A e B. Isto pode ser explicado, pois neste caso, componentes individuais do complexo bacitracina são isolados e purificados, excluindo outros componentes que possam aumentar a atividade antimicrobiana deste antibiótico.

\subsubsection{Produção de sideróforo pela linhagem $P$. putida TP16}

A curva de crescimento (Figura 20) para o isolado P. putida TP16 foi realizada em meio MM9 sem a presença de ferro, porém o crescimento bacteriano não foi prejudicado pelo uso deste meio de cultura. A partir dos resultados da produção de sideróforo em meio sólido, que mostraram a elevada produção deste composto, decidiu-se estudar o crescimento bacteriano de $P$. putida TP16 concomitantemente com a produção de sideróforos, a fim de avaliar o melhor período para interromper o crescimento e obter a maior quantidade do composto. 
O crescimento do isolado $P$. putida TP16 foi mantido até a fase final logarítmica, quando a ocorre a produção máxima de sideróforo. O mesmo resultado foi obtido por SILVASTENICO et al. (2005), usando cultura de Xylella fastidiosa.

A Figura 20 apresenta a relação entre crescimento microbiano e produção de sideróforo.

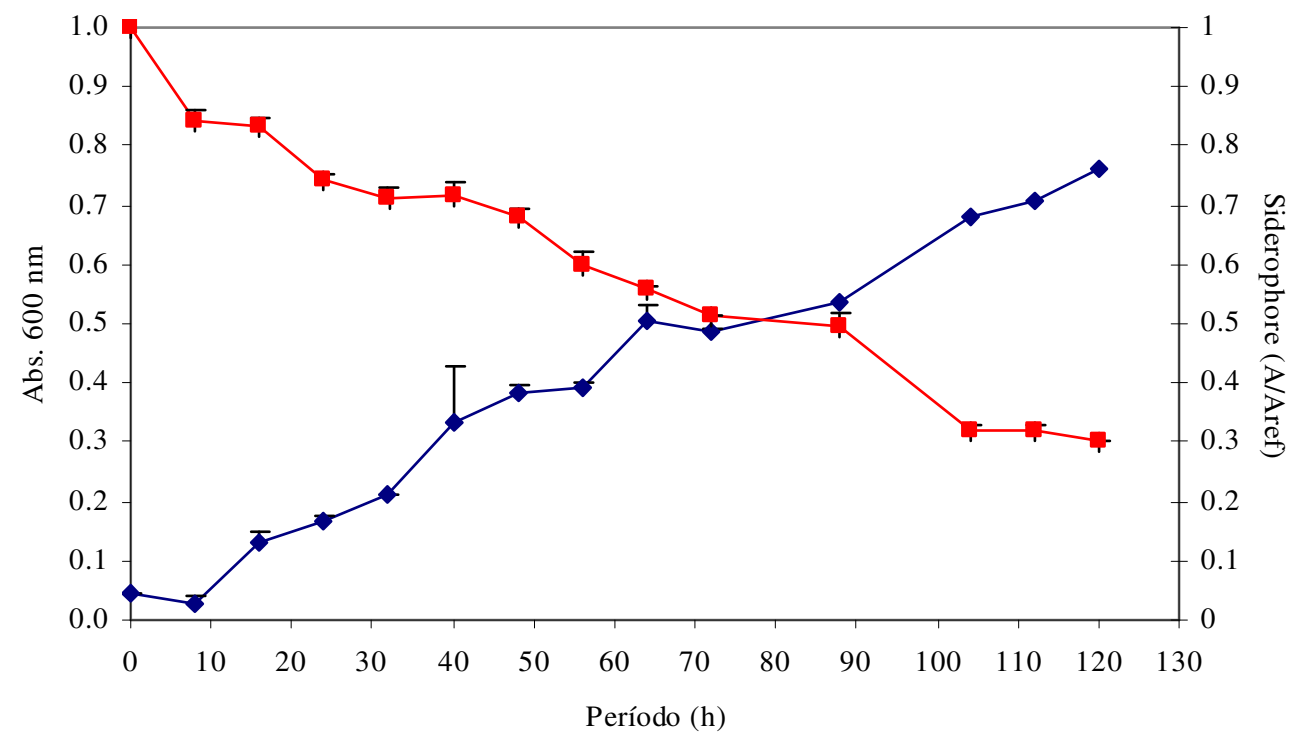

Figura 20. Curva de crescimento $(\diamond)$ de $P$. putida TP16 e produção de sideróforo $(\square)$.

Apesar da cultura ainda não ter atingido a fase estacionária, a detecção de sideróforos pôde ser confirmada através dos testes de CAS líquido (Figura 21). 


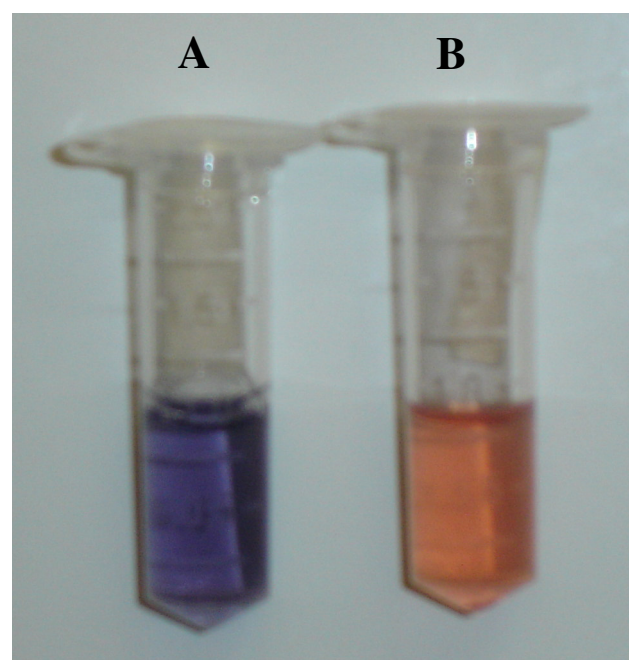

Figura 21. Detecção de sideróforo em sobrenadante de $P$. putida TP16 em solução de CAS. A) CAS + MM9 (controle); B) CAS + sobrenadante de P. putida TP16.

O complexo cromoazurol S-Fe ${ }^{3+}$ pode ser utilizado para detectar se houve produção de sideróforos, uma vez que o teste é baseado na troca competitiva por $\mathrm{Fe}^{3+}$ e as substâncias quelantes são detectáveis de acordo com a afinidade pelo metal. Dessa forma, quelantes fortes como os sideróforos reagem em uma proporção de 1:1, enquanto os quelantes fracos necessitam estarem presentes em excesso para a formação do complexo quelante com o ferro, que é indicado pela liberação do corante livre de ferro acompanhada de alteração da coloração (SCHWYN; NEILANDS, 1987).

\subsubsection{Cromatografia em camada delgada}

Os extratos foram submetidos à CCD na tentativa para otimização na separação dos compostos presentes (Figura 22 e 23). Na técnica de CCD pôde-se constatar a presença no extrato em acetato de etila de 1 "spot"; no extrato em clorofórmio também foi observado 1 "spot" diferentes dos extratos controle (meio de cultura MM9 extraído em acetato de etila e clorofórmio). Os "spots" foram visíveis sob lâmpada UV nos comprimentos de onda a $254 \mathrm{~nm}$ 
e $366 \mathrm{~nm}$. Os "spots" dos respectivos extratos foram visualizados e suas distâncias de migração calculadas (Tabela 11).

Tabela 11 - Rfs das frações dos extratos visualizados sob lâmpada UV com dois comprimentos de onda $(254 / 366 \mathrm{~nm})$.

\begin{tabular}{ccc}
\hline \hline Extratos & $\mathbf{3 6 6} \mathbf{~ n m}$ & $\mathbf{2 5 4} \mathbf{~ n m}$ \\
$\mathbf{R f}$ & $\mathbf{R f}$ \\
\hline $\begin{array}{c}\text { Controle } \\
\text { Acetato de etila }\end{array}$ & 0,9 & 0,9 \\
\hline $\begin{array}{c}\text { Controle } \\
\text { clorofórmio }\end{array}$ & 0 & 0 \\
\hline $\begin{array}{c}\text { sobrenadante } \\
\text { Acetato de etila }\end{array}$ & 0 & 0,3 \\
\hline sobrenadante \\
clorofórmio
\end{tabular}

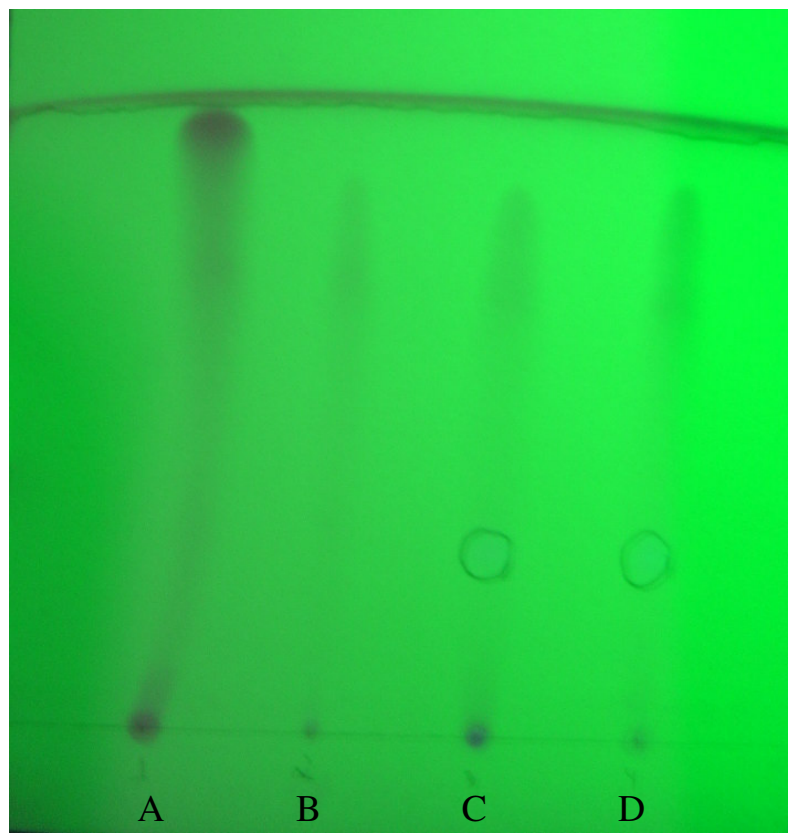

Figura 22. CCD dos extratos de P. putida TP16. A) MM9 em acetato de etila (controle); B) MM9 em clorofórmio (controle); C) P. putida TP16 em acetato de etila; D) $P$. putida TP16 em clorofórmio. Solvente de eluição: hexano:acetato de etila:ácido acético (55:45:0.1) (v/v). $366 \mathrm{~nm}$. 
A maioria dos catecolatos são derivados do ácido 2,3-dihidroxibenzóico (2,3-DHBA) e consistem de 2,3-DHBA mais um resíduo de aminoácido (XIE et al., 2006). Muitas bactérias incluindo Pseudomonas stutzeri, Azotobacter vinelandii, Rhizobium trifolii, Bacillus spp., etc., são capazes de excretar sideróforos do tipo catecol (HÖFTE, 1993; CARRERO et al., 2002). Algumas linhagens produzem mais do que um sideróforo do tipo catecol (HÖFTE, 1993; GAITATZIS et al., 2005; RABSCH et al., 2003).

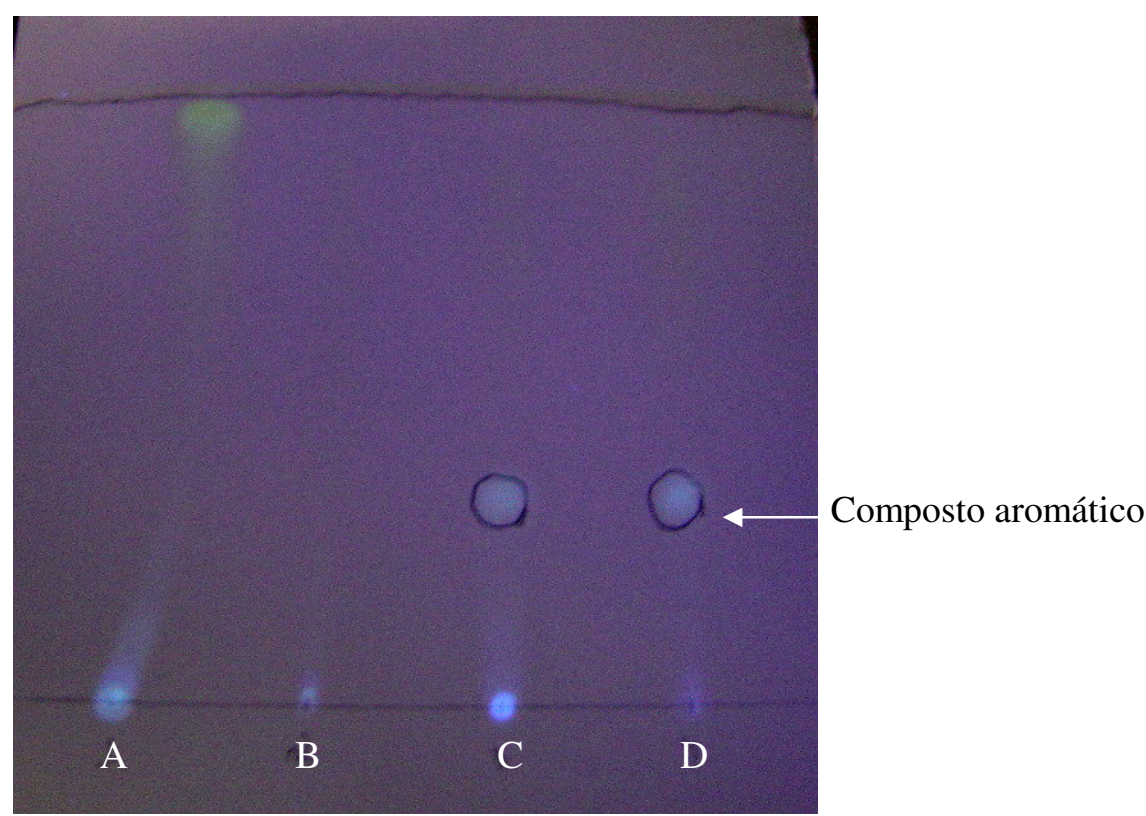

Figura 23. CCD dos extratos de $P$. putida TP16. A) MM9 em acetato de etila (controle); B) MM9 em clorofórmio (controle); C) P. putida TP16 em acetato de etila; D) $P$. putida TP16 em clorofórmio. Solvente de eluição: hexano:acetato de etila:ácido acético (55:45:0.1) (v/v). $254 \mathrm{~nm}$.

CCD em silica é comumente usada para analisar compostos catecólicos simples, tais como 2,3-DHBA e catecol, porém é ineficiente para distinguir misturas complexas de sideróforos do tipo catecol. O grupo de XIE et al. (2006) sugere o uso de CCD em poliamida, pois esta tem um material absorvente para este tipo de sideróforo superior ao da sílica. 
Sideróforos foram identificados de isolados de Erwinia sp, através de análise de CCD. Os resultados indicaram que o isolado produz três diferentes tipos de sideróforos do tipo catecol (XIE et al., 2006).

\subsubsection{Espectrometria de massas}

Os resultados obtidos pela técnica de espectrometria de massas estão representados nas Figura 24 A e B. As análises por Q-TOF foram feitas usando ambos extratos de acetato de etila e clorofórmio, tanto das amostras quando dos controles. Essa estratégia é utilizada para a separação de produtos diversos e são também usadas como técnica de identificação, quando o composto já é conhecido.

A identificação do metabólito presente nos extratos foi feita por ESI através da comparação de suas massas com dados de um dicionário químico de compostos (CHEMICAL DICTIONARY, 1997), o qual contém informações sobre substâncias químicas. Através desta busca pôde-se encontrar um metabólito conhecido por pseudomonina, produzido pela bactéria P. fluorescens AH2 (ANTHONI et al., 1995) com atividade quelante (sideróforo positiva).

O isolado P. putida TP16 estudado neste trabalho foi eficiente na produção de metabólitos secundários quando crescido em meio de cultura líquido MM9 sem ferro. Geralmente o meio MM9 estimula a grande produção de sideróforos comparados com outros meios estudados. Os espectros de massas obtidos para pseudomonina estão apresentados na Figura 24, visando a sua identificação via Q-TOF. 


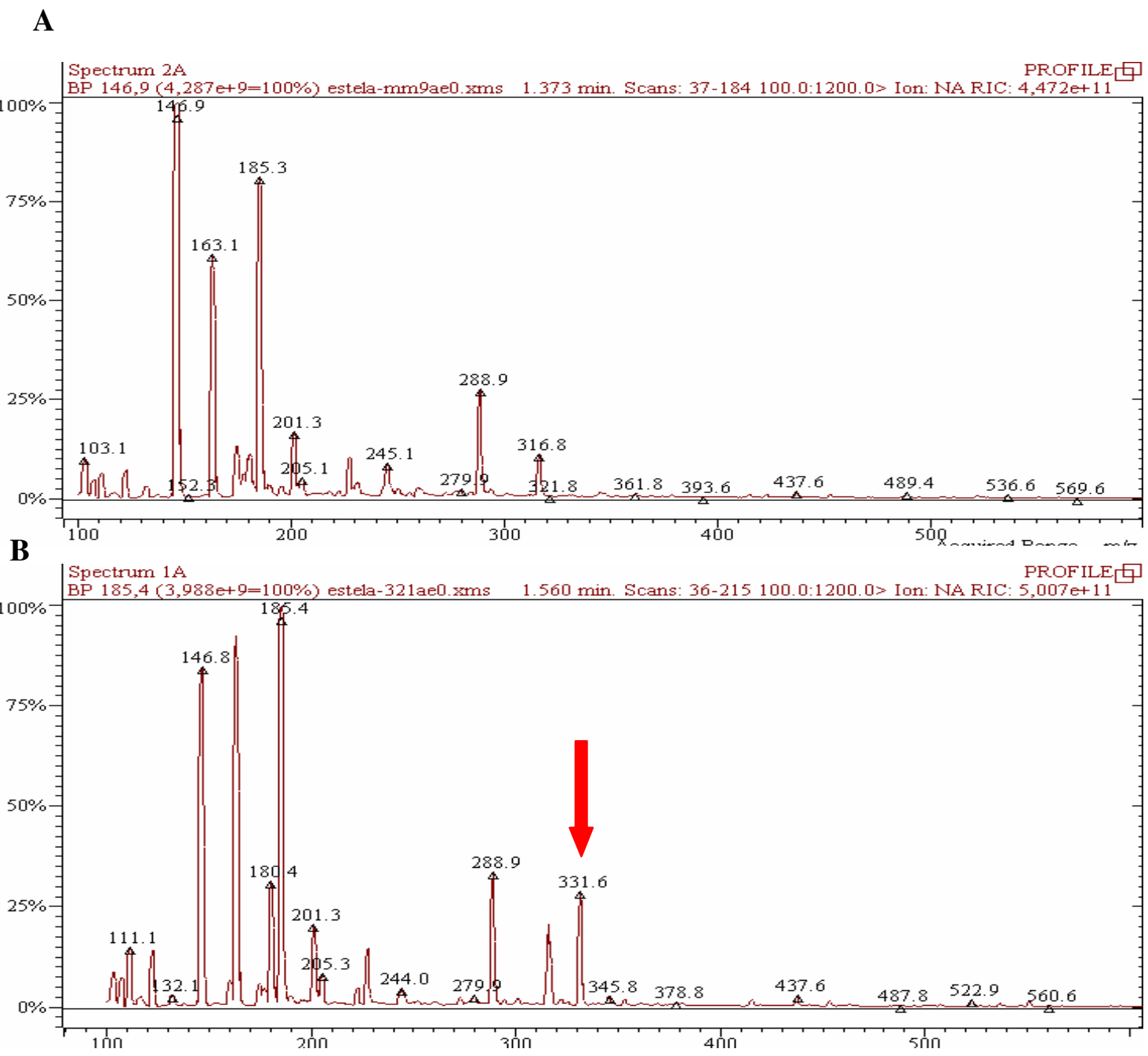

Figura 24. Espectros de electrospray (ESI) de pseudomonina em modo positivo. A) MM9 em acetato de etila (controle) e B) extrato de P. putida TP16 em acetato de etila.

Depois de obtido o espectro buscou-se em literaturas específicas a estrutura do composto, pseudomonina. A estrutura pode ser observada de acordo com a Figura 25.<smiles>CC1ON(CCc2c[nH]cn2)C(=O)C1NC(=O)c1ccccc1O</smiles>

Figura 25. Estrutura química do sideróforo pseudomonina (ANTHONI et al., 1995). 
ANTHONI et al. (1995) isolaram a pseudomomina, um alcalóide com atividade de sideróforo de culturas de $P$. fluorescens AH2. Foi o primeiro estudo a relatar esse sideróforo. A fórmula molecular deste composto é $\mathrm{C}_{16} \mathrm{H}_{18} \mathrm{~N}_{4} \mathrm{O}_{4}$ e foi caracterizada por estes autores possuindo MM de 330 Da. Esse sideróforo provavelmente tem um papel na supressão de doenças em plantas (CROSA; WALSH, 2002).

GRAM et al. (1999) avaliaram a inibição de Vibrio anguillarum por P. fluorescens $\mathrm{AH} 2$, sendo um possível probiótico no tratamento de peixes. Os testes in vitro e in vivo apresentaram os mesmos resultados. O ferro é um importante fator para a virulência e interações bacterianas. Em condições com baixo ferro $P$. putida inibiu o crescimento de $V$. anguillarum, o que não ocorreu em meio rico em ferro. O probiótico combinado ao tratamento resultou na redução de $46 \%$ da mortalidade sendo que nos peixes não tratados com o probiótico a mortalidade foi de $47 \%$.

MERCADO-BLANCO et al. (2001) analisaram o gene pmsCEAB envolvidos na biossíntese de ácido salicílico e do sideróforo pseudomonina do isolado $P$. fluorescens WCS374. O sideróforo foi analisado no modo positivo usando ESI-Q-TOF. O mesmo espectro foi obtido por ANTHONI et al. (1995), uma molécula protonada foi observada a $\mathrm{m} / \mathrm{z}$ 331. MERCADO-BLANCO et al. (2001) obtiveram informação estrutural desta molécula através de fragmentação onde o íon a $\mathrm{m} / z 331$ foi submetido à dissociação induzida por colisão (CID). A molécula fracionada (Figura 26) apresenta o perfil de fragmentação. De acordo com os autores, o fragmento do íon mais abundante observado foi a $\mathrm{m} / \mathrm{z} 211$ e corresponde a perda do grupo ácido salicílico (AS). O fragmento do grupo AS foi observado à $m / z$ 121. O íon a $m / z 110$ corresponde ao íon imônium histidina, o qual é derivado de parte da histamina, enquanto os íons a $\mathrm{m} / \mathrm{z} 82$ e 95 também aparecem pela quebra da cadeia de 
hidrocarboneto de parte da histamina. $\mathrm{O}$ íon a $\mathrm{m} / \mathrm{z} 138$ corresponde à quebra de parte da ciclotreonina com retenção de carga sobre a parte da molécula contendo histamina. O íon a $m / z 204$ derivou da porção da molécula que contém AS e é gerado pela quebra da ciclotreonina. Este íon é complementado por um íon à $\mathrm{m} / z 128$ que aparece através de uma quebra semelhante à ciclotreonina, mas sem a retenção de carga da parte da molécula que contém histamina.

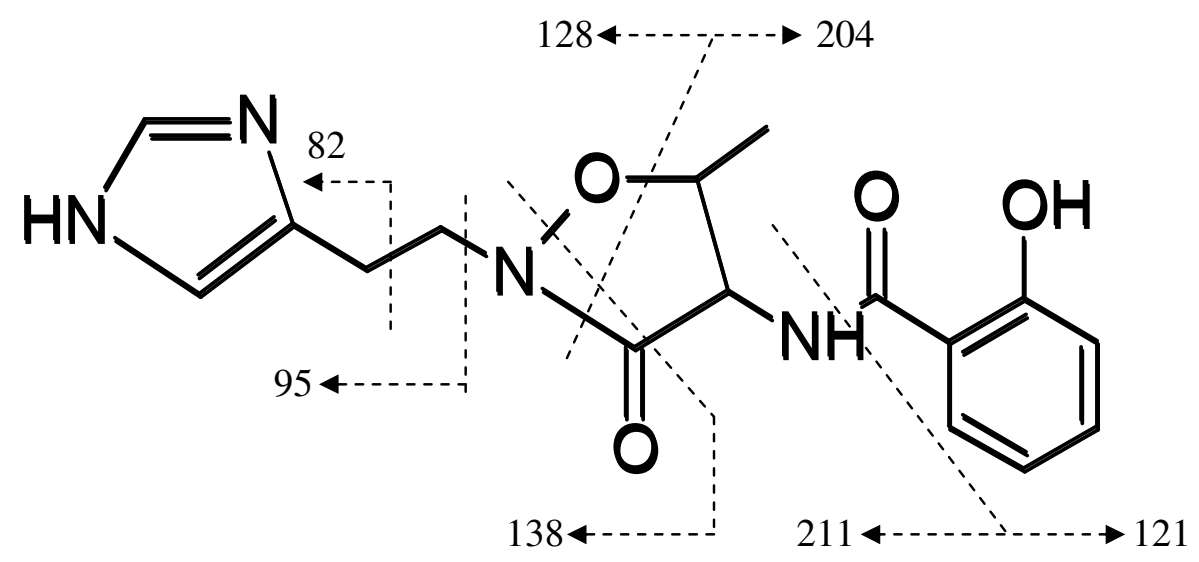

Figura 26. Esquema de fragmentação para o íon $[\mathrm{M}+\mathrm{H}]^{+}$a $\mathrm{m} / z 331$ do presente estudo, modificado a partir de MERCADO-BLANCO et al. (2000). Os números indicam os fragmentos de massas dos íons obtidos. 


\section{CONCLUSÕES}

Há muitas razões para que se aprofundem os estudos com microrganismos de Terra Preta Antropogênica. Primeiro, a falta de informações para elucidar a diversidade biológica desse bioma. Segundo, porque devido ao TPA ser um solo muito fértil, torna-a vantajosa, pois muitos benefícios para o solo têm sido atribuídos, já que a maioria dos microrganismos deste solo tem um potencial para produzir uma diversidade de metabólitos secundários com várias aplicações em biotecnologia, incluindo o de drogas de uso farmacêutico como os antibióticos e agentes anticancerígenos. Neste estudo, foram isoladas 143 bactérias de solos TPA e adjacência, estas agrupadas em 8 diferentes gêneros. Com base nos resultados apresentados pode-se concluir que:

A maioria dos isolados que produziram sideróforos e apresentaram os genes NRPS e PKS foram provenientes de profundidades que variaram de 0 a $20 \mathrm{~cm}$, tanto em TPA com em solo adjacente. Os genes que codificam para as enzimas NRPS e PKS aparecem em 55\% dos isolados e estão distribuídos com maior concentração nas linhagens isoladas de solos adjacentes à TPA.

Foi constatado o potencial dos isolados para produção de sideróforos, os quais têm um papel importante em termos ecológicos e biotecnológicos, principalmente quanto ao gênero Pseudomonas e Bacillus, mais freqüentemente encontrados nos solos adjacentes à TPA.

Os isolados TP11 e TP16 correspondem ao gênero Pseudomonas, identificados pelos testes pela produção distinta de sideróforos, o primeiro sem identificação clara da classe de sideróforo e o segundo, produzindo ambas as classes - hidroxamato e catecol. Através da 
espectrometria de massas foi possível identificar um composto conhecido como pseudomonina com MM de 330 Da produzido pelo isolado $P$. putida TP16, um sideróforo com atividade antimicrobiana, identificada anteriormente em Pseudomonas.

Os resultados obtidos através da utilização de técnicas bioquímicas e moleculares em conjunto permitiram correlacionar a produção de sideróforos e antimicrobianos com a presença dos genes de NRPS e PKS, sugerindo que a produção destes compostos pode ocorrer pela via não ribossomal. 


\section{REFERÊNCIAS BLIOGRÁFICAS}

ALTSCHUL, S.F.; GISH, W.; MILLER, W.; MEYERS, E.W.; LIPMAN, D.J. Basic local alignment search tool. Journal of Molecular Biology, London, v.215, p.403-410, 1990.

ANDERSON, T. H.; DOMSCH, K. H. The metabolic quotient for $\mathrm{CO}_{2}(\mathrm{qCO} 2)$ as a specific activity parameter to assess the effects of environmental conditions, such as $\mathrm{pH}$, on the microbial biomass of forest soils. Soil Biology \& Biochemistry, Oxford, v. 25, p. 393-395. 1993.

ANSARI, M. Z.; YADAV, G.; GOKHALE, R. S.; MOHANTY, D. NRPS-PKS: a knowledge-based resource for analysis of NRPS/PKS megasynthases. Nucleic Acids Research, London, v. 32, p.405-413, 2004.

ANTHONI, U.; CHRISTOPHERSEN, C.; NIELSEN P.H.; GRAM L., PETERSEN B.O. Pseudomonine, an isoxazolidone with siderophoric activity from Pseudomonas fluorescens AH2 isolated from lake Victorian nile perch. Journal of Natural Products, Pittsburgh, v.58, p.11, p.1786-1789, 1995.

ARNOW, L.E. Colorimetric determination of the components of 3,4-dihydroxyphenylalaninetyrosine mixtures. Journal of Biological Chemistry, Baltimore, v.118, p. 531-537, 1937.

BANERJEE, S.; HANSEN, J.N. Structure and expression of a gene encoding the precursor of subtilin, a small protein antibiotic. Journal of Biological Chemistry, Baltimore, v.263, p.9508-9514, 1988.

BEIER, R.C.; STANKER, L.H. Immunoassays for residue analysis: Food safety, American Chemical Society, Symposium Series 621, Washington DC, USA, 1996.

BENITE, A. M.; MACHADO, S. P.; MACHADO, B. C. Sideróforos: Uma resposta dos microrganismos. Química Nova, São Paulo, v.25, n.6B, p.1155-1164, 2002.

BEYER, S.; KUNZE, B.; SILKOWSKI, B.; MÜLLER, R. Metabolic diversity in myxobacteria: identification of the myxalamid and the stigmatellin biosynthetic gene cluster of Stigmatella aurantiaca Sg a15 and a combined polyketide-(poly)peptide gene cluster from the epthilone producing strain Sorangium cellulosum So ce90. Biochimica et Biophysica Acta, Amsterdam, v. 1445, p.185-195, 1999.

BENTON, M.J.; AYALA, F. J. Dating the Tree of Life. Science, Washington, v.300, p.1698-1700, 2003. 
BERTANI, G. Studies on lysogenesis. I. The mode of phage liberation by lysogenic Escherichia coli. Journal of Bacteriology, Baltimore, v.62, p.293-300, 1951.

BICKEL, H.; FECHTIG, B.; HALL, G.E.; KELLERSCHIERLEIN, W.; PRELOG, V.; VISCHER, E. Stoffwechselprodukte von actinomyceten .24. uber die isolierung und synthese des 1-amino-5-hydroxylamino-pentans, eines wesentlichen hydrolyseproduktes der ferrioxamine und der ferrimycine helvetica. Chimica Acta, Amsterdan, v.43, p.901-904, 1960.

BIEDERMANN, G.; SCHINDLER, P. On the solubility of precipitated iron (III) hydroxide. Acta Chemica Scandinavica, Copenhagen, vol. 11, p. 731-740, 1957.

BORNEMAN, J.; TRIPLETT, E. W. Molecular microbial diversity in soils from eastern Amazonia: Evidence for unusual microorganisms and microbial population shifts associated with deforestation. Applied and Environmental Microbiology, Baltimore, v.63, p. 26472653, 1997.

BRAUD, A.; JEZEQUEL, K.; LEGER, M.A.; LEBEAU, T. Siderophore production by using free and immobilized cells of two pseudomonads cultivated in a medium enriched with $\mathrm{Fe}$ and/or toxic metals $(\mathrm{Cr}, \mathrm{Hg}, \mathrm{Pb})$. Biotechnology and Bioengineering, New York, v.94, p.1080-1088, 2006.

BUCHMAN, G.W.; BANERJEE, S.; HANSEN, J.N. Structure, expression, and evolution of a gene encoding the precursor of nisin, a small protein antibiotic. Journal of Biological Chemistry, Baltimore, v.263, p.16260-16266, 1988.

CARRERO, M.I.G.; SANGARI, F.J.; AGUERO, J. Brucella abortus strain 2308 produces brucebactin, a highly efficient catecholic siderophore. Microbiology, Reading, v.48, p.353$360,2002$.

CHALLIS, G.L.; NAISMITH, J.H. Structural aspects of non-ribosomal peptide biosynthesis Current Opinion in Structural Biology, London, v. 14 , p.748-756, 2004.

CHEN. S.; VON BAMBERG, D.; HALE, V. Biosynthesis of ansatrienin (mycotrienin) and naphthomycin - Identification and analysis of two separate biosynthetic gene clusters in Streptomyces collinus Tu 1892. European Journal of Biochemistry, Oxford, v.261, p.98107, 1999.

CHEMICAL DICTIONARY. Chapman \& Hall Chemical Dictionaries on Natural Products 1982-97. 1 CD-ROM, 1997. 
COX, C.D.; RINEHART, K.L.; MOORE, M.L. Pyochelin - Novel structure of an ironchelating growth promoter for Pseudomonas aeruginosa. Proceedings of the National Academy of Sciences of the United States of America, Biological Science, Washington, v.78, p.4256-4260, 1981.

CROSA, J.H, WALSH, C.T. Genetics and assembly line enzymology of siderophore biosynthesis in bacteria. Microbiology and Molecular Biology Reviews, Washington, v.66, p.223-249, 2002.

CSÁKY, T. Z. On the estimation of bound hydroxylamine in biological materials. Acta Chemica Scandinavica, Copenhagen, v.2, p. 450-454, 1948.

CULLIMORE, D. R. Gram negative strictly aerobic rods and cocci. In: Pratical Atlas for Bacterial Identification. USA.ed. CRC Press LLC. 2000. p. 13-25.

DAVAGNINO, J.; HERRERO, M.; FURLONG, D.; MORENO, F.; KOUTE, R. The DNA replication inhibitor microcin B17 is a fourty-three amino- acid protein containing sixty percent glycine. Proteins, New York, v.1, p.230-238, 1986.

DAVIES, J. What are antibiotics? Archaic functions for modern activities. Molecular Microbiology, Oxford, v.4, p.1227-1232, 1990.

DEAN, C. R.; POOLE. K.. Cloning and characterization of the ferric enterobactin receptor gene ( $p f e A$ ) of Pseudomonas aeruginosa. Journal of Bacteriology, Baltimore. 175:317-324. 1993.

DEMAIN, A. Microbial secondary metabolism: a new theoretical frontier for academia, a new opportunity for industry. In: Secondary metabolites: their function and evolution. Chichester: J. Wiley, Nova York, 1992. p.3-23.

DIEKMANN, H. Metabolic products of microorganisms .81. Occurrence and structures of coprogen-b and dimerum acid. Archives fur Mikrobiologie, Heidelberg, v.73, p. 75, 1970.

DONADIO, S.; MONCIARDINI, P.; ALDUINA, R.; MAZZA, P.; CHIOCCHINI, C.; CAVALETTI, L.; SOSIO, M.; PUGLIA, A. M. Microbial technologies for the discovery of novel bioactive metabolites. Journal of Biotechnology, Amsterdam, v. 99, p. 187-198, 2002.

DOYLE, J. J. T.; DOYLE, J. L. Isolation of plant DNA from fresh tissue. Focus, Rochester, v. 12, p. 13-18, 1990. 
DU, L.C.; SHEN, B. Identification and characterization of a type II peptidyl carrier protein from the bleomycin producer Streptomyces verticillus ATCC 15003. Chemical Biology, London, vol. 6, p. 507-517, 1999.

DUBEY, S. K.; TRIPATHI, A. K., UPADHYAY, S. N. Exploration of soil bacterial communities for their potential as bioresource. Bioresource Technology, New York, v.97, p.2217-2224, 2006.

DUITMAN, E. H.; HAMOEN, L. W.; REMBOLD, VENEMA, G.; SEITZ, H.; SAENGER, W.; BERNHARD, F.; REINHARDT, R.; SCHMIDT, M.; ULLRICH, C.; STEIN, T.; LEENDERS, F.; VATER, J. The mycosubtilin synthetase of Bacillus subtilis ATCC6633: a multifunctional hybrid between a peptide synthetase, an amino transferase, and a fatty acid synthase. Proceedings of the National Academy of Sciences of the USA, Washington, v. 96, p.13294-13299, 1999.

ERNST, J.F.; BENNETT, R.L.; ROTHFIELD, L.I. Constitutive expression of the ironenterochelin and ferrichrome uptake systems in a mutant strain of Salmonella typhimurium Journal of Bacteriology, Baltimore, vol. 135, p. 928-934, 1978.

ERWIN, T. L. The tropical forest canopy-the heart of biotic diversity, p. 123-129. In: WILSON, E. O. (Ed.). Biodiversity. Washington, D.C.: National Academy Press, 1988.

ETCHEGARAY, A. Biossíntese de antibióticos peptídicos em microrganismos. In: MELO, I.S.; AZEVEDO, J.L. Ecologia Microbiana. Jaguariúna: Embrapa-CNPMA, 1998. p.393419.

ETCHEGARAY, A.; RABELO, E.; DIECKMANN, R.; MOON, D.H. Algicide production by filamentous cyanobacterium Fischerella sp. CENA 19. Journal of Applied Phycology, Dordrecht, v.16, p.237-243, 2004a.

EWING, B.; GREEN, P. Base-calling of automated sequencer traces using phred. II. Error probabilities. Genome Research, Woodbury, v. 8, n. 3, p. 186-194, 1998.

EWING, B.; HILLIER, L.; WENDL, M. C.; GREEN, P. Base-calling of automated sequencer traces using phred. I. Accuracy assessment. Genome Research, Woodbury, v. 8, p. 175-185, 1998.

FERNANDEZ-MORENO, M.A.; VALLIN, C.; MALPARTIDA, F. Streptothricin biosynthesis is catalyzed by enzymes related to nonribosomal peptide bond formation. Journal of Bacteriology, Baltimore, vol. 179, p. 6929-6936, 1997. 
FIERER, N.; JACKSON, R. B. The diversity and biogeography of soil bacterial communities. Proceedings of the National Academy of Sciences of the USA, Washington, v. 103, n. 3, p. 626-631, 2006.

GAITATZIS, N.; KUNZE, B.; MULLER, R. Novel insights into siderophore formation in myxobacteria. Chembiochem, New York, v.6, p.365-374, 2005.

GARCIA, C.E. Isolamento e identificação de actinobactérias em solos de Terra Preta Antropogênica (TPA) da Amazônia Central por ARDRA e seqüenciamento do gene 16S rRNA. 106 p. Tese (Doutorado em Ciência de Alimentos) - Faculdade de Engenharia de Alimentos, Universidade Estadual de Campinas, 106 f., Campinas, 2006.

GEHRING, A.M.; MORI, I.; WALSH, C.T. Reconstitution and characterization of the Escherichia coli enterobactin synthetase from EntB, EntE, and EntF. Biochemistry, New York, v. 37, p. 2648-2659, 1998.

GHYSELS, B., U.; OCHSNER, U.; MOLLMAN, L.; HEINISCH, M.; VASIL, P.; CORNELIS, S. M. The Pseudomonas aeruginosa pirA gene encodes a second receptor for ferrienterobactin and synthetic catecholate analogues. FEMS Microbiology Letters, Birmingham, v.246, p.167-174, 2005.

GLASER, B.; GUGGENBERGER, G.; HAUMAIER, L.; ZECH, W. Persistence of soil organic matter in archaeological soils (Terra Preta) of the Brazilian Amazon region. In: REES, R. M.; BALL B. C.; CAMPBELL, C. D.; WATSON, C. A. (Ed.). Sustainable management of soil organic matter. Wallingford, 2001. p. 190-194.

GORDON, D.; ABAJIAN, C.; GREEN, P. Consed: a geographical tool for sequence finishing. Genome Research, Woodbury, v. 8, p. 195-202, 1998.

GRAM, L.; BUNDVAD, A.; MELCHIORSEN, J.; JOHANSEN, C.; VOGEL, B.F. Occurrence of Shewanella algae in Danish coastal water and effects of water temperature and culture conditions on its survival. Applied and Environmental Microbiology, Baltimore, v.65, p.3896-3900, 1999.

GRIFFITHS, G.L.; SIGEL, S.P.; PAYNE, S.M.; NEILANDS, J.B. Ibriobactin, a siderophore from Vibrio-cholerae. Journal of Biological Chemistry, Bethesda, .v.259, p.383-385, 1984.

HALL, T. BioEdit - version 5.0.6 Raleigh: North Caroline State University, Department of Microbiology, 2001. 192p. 
HACKL，E.; ZECHMEISTER-BOLTENSTERN， S.; BODROSSY，L.; SESSITSCH, A. Comparison of diversities and compositions of bacterial populations inhabiting natural forest soils. Applied and Environmental Microbiology, Baltimore, v.70, p.5057-5065.

HÖFTE, M. Classes of microbial siderophores. In: Barton, Larry.L. (Eds.), Iron Chelation in Plants and Soil Microrganisms, Academic Press, San Diego, 1993, p.3-26.

HOWELL, C. R. Stipanovic, Control of Rhizoctonia solani on cotton seedlings by Pseudomonas fluorescens and and antibiotic produced by the bacterium. Phytopathology, Saint Paul, v.69, p.480-482, 1980.

JACKSON, R.B.; LINDER, C.R.; LYNCH, M. Linking molecular insight and ecological research. Trends in Ecology \& Evolution, Amsterdam, v.17, p.409-414, 2002.

JENKE-KODAMA, H.; DANDMANN, A.; MULLER, R.; DITTMANN, E. Evolutionary implications of bacterial polyketide synthases. Molecular Biology and Evolution, Chicago, v. 22, n. 10, p. 2027-2039, 2005.

JORGENSEN, R.A.; CLUSTER, P.D. Modes and temps in the evolution of nuclear ribossomal DNA: new characters for evolutionary studies and new markers for genetic and population studies. Annual Missouri Botanical Garden, Saint Louis, v.75, p.1238-1247, 1989.

KERN, D. C.; KÄMPF, N. Antigos assentamentos indígenas na formação de solos com Terra Preta Arqueológica na região de Oriximiná, Pará. Revista Brasileira de Ciência do Solo, Viçosa, v. 13, p. 219-225, 1989.

KIRK, J.L.; BEAUDETTE, L.A.; HART, M.; MOUTOGLIS, P.; KLIRONOMOS, J.N.; LEE, H; TREVORS, J.T. Methods of studying soil microbial diversity. Journal of Microbiological Methods, Dordrecht, v.58, p.169-188, 2004.

KLEINKAUF, H; VONDOHREN, H. Biosynthesis of peptide antibiotics. Annual Review of Microbiology, Palo Alto, v.41, p.259-289, 1987.

KLEINKAUF, H.; VON DÖHREN, H. Nonribosomal biosyntesis of peptide antibiotics. European Journal of Biochemistry, Oxford, v. 192, p. 1-9, 1990.

KLEINKAUF, H.; VON DÖHREN, H. A nonribosomal system of peptide biosynthesis European Journal of Biochemistry, Oxford, vol. 236, p.335-351, 1996. 
KOLTER, R.; MORENO, F. Genetics of ribosomally synthesized peptide antibiotics. Annual Review of Microbiology., Palo Alto, v. 46, p.141-163, 1992.

KUMAR, S.; TAMURA, K.; NEI, M. MEGA 3: Integrated Software for Molecular Evolutionary Genetics Analysis and Sequence Alignment. Briefings in Bioinformatics, Oxford, vol. 5, p. 150-163, 2004.

LAMBAIS, M. R.; CROWLEY D. E; CURY J.; C., BULL, R. C.; RODRIGUES, R. R. Bacterial diversity in tree canopies of the Atlantic forest. Science, Washington, v. 312, p. 1917, 2006.

LEHMANN, J.; KERN, D. C.; GLASER, B.; WOODS, W. I. (Ed.). Amazonian Dark Earth: Origin, properties \& management. Kluwer Academic Publishers, Dordrecht, 2003. 505 p.

LINDUM, P.W.; ANTHONI, U.; CHRISTOPHERSEN, C.; EBERL, L.; MOLIN, S.; GIVSKOV, M. N-acyl-L-homoserine lactone autoinducers control production of an extracellular lipopeptide biosurfactant required for swarming motility of Serratia liquefaciens MG1. Journal of Bacteriology, Baltimore, v.180, p.6384-6388, 1998.

LIPMANN, F. Attempts to map a process evolution of peptide. Biosynthesis Science, London, v.173, p.875, 1971.

LIU, W.T.; MARSH, T.L.; CHENG, H.; FORNEY, L.J. Characterization of microbial diversity by determining terminal restriction fragment length polymorphisms of genes encoding 16S rRNA. Applied and Environmental Microbiology, Baltimore, v.63, p.45164522, 1997.

LLAMAS, M. A.; SPARRIUS, M.; KLOET, R.; JIME`NEZ, C. R.; VANDENBROUCKEGRAULS C.; BITTER, W. The heterologous siderophores ferrioxamine B and ferrichrome activate signaling pathways in Pseudomonas aeruginosa. Journal of Bacteriology, Baltimore. v.188, p. 1882-1891, 2006.

LOUWS, F. J.; RADEMAKER, J. L. W.; BRUIJN, F. J. The three Ds of PCR-based genomic analysis of phytobacteria: diversity, detection, and disease diagnosis. Annual Review of Phytopathology, Palo Alto, v. 37, p. 81-125, 1999.

LUCA, DE N. G.; WEXLER, M.; PEREIRA, M.J.; YEOMAN, K.H.; JOHNSTON, A.W.B. Is the fur gene of Rhizobium leguminosarum essential? FEMS Microbiology Letters, Amsterdam, v.168, p.289-295, 1988.

MARAHIEL, M.A. Multidomain enzymes involved in peptide-synthesis FEBS LETTERS, Amsterdam, v.307, p.40-43, 1992. 
MARTIN, J.F.; DEMAIN, A.L. Control of antibiotic synthesis. Microbiological Reviews, Amsterdam, v.44, p.230-251, 1980.

MARTIN-LAURENT, F.; PHILIPPOT, L.; CHAUSSOD, R.; GERMON, J. C.; SOULAS, G.; CATROUX, G. DNA Extraction from soils: old bias for new microbial diversity analysis methods. Applied and Environmental Microbiology, Baltimore, v. 76, p. 2354-2359, 2001.

MATSUMOTO, M.; TSUNEMATSU, K.; TSUJI, A.; KIDO, Y. Enzyme immunoassay using peroxidase as a label and a dip-strip test for monitoring residual bacitracin in chicken plasma. Analytica Chimica Acta, Amsterdam, vol.346, n.2, p.207-213, 1997.

MERCADO-BLANCO, J.; VAN DER DRIFT, K.M.G.M.; OLSSON, P.E.; THOMASOATES, J.E.; VAN LOON, L.C.; BAKKER, P.A.H.M. Analysis of the pmsCEAB gene cluster involved in biosynthesis of salicylic acid and the siderophore pseudomonine in the biocontrol strain Pseudomonas fluorescens WCS374. Journal of Bacteriology, Baltimore, v.183, p.1909-1920, 2001.

NAIK, P. R.; SAKTHIVEL, N. Functional characterization of a novel hydrocarbonoclastic Pseudomonas sp. Strain PUP6 with plant-growth-promting trats and antifungal potential. Research in Microbiology, Paris, v. 157, p. 538-546, 2006.

NEILAN, B.A. ; DITTMANN, E. ; ROUHIAINEN, L. ; BASS, R.A. ; SCHAUB, V. ; SIVONEN, K. ; BÖRNER, T. Nonribosomal peptide synthesis and toxigenicity of cyanobacteria. Journal of Bacteriology, Baltimore, v.181, p.4089-4097, 1999.

NEILANDS, J.B. Iron absorption and transport in microorganisms. Annual Review of Nutrition, Palo Alto, v.1, p.27-46, 1981.

NEILANDS, J.B. Isolation and assay of 2,3-dihydroxybenzoyl derivatives of polyamines - the siderophores agrobactin and parabactin from Agrobacterium tumefaciens and Paracoccus denitrificans. Methods in Enzymology, New York, v.94, p.437-441, 1983.

NEILANDS, J. B. Siderophores of bacteria and fungi. Microbiological Sciences, Oxford, v. 1, p. 9-14, 1984.

NEILANDS, J. B. Siderophores - structure and function of microbial iron transport compounds. Journal of Biological Chemistry, Baltimore, v.270, p. 26723-26726, 1995. 
OHRA, J.; MORITA, K.; TSUJINO, Y.; TAZAKI, H.; FUJIMORI, T.; GOERING, M.; EVANS, S.; ZORNER, P. Production of the phytotoxic metabolite, ferricrocin, by the fungus Colletotrichum gloeosporioides. Bioscience Biotechnology and Biochemistry, Tokyo, v.59, p.113-114, 1995.

OMURA, S. Trends in the search for bioactive microbial metabolites. Journal of Industrial Microbiology, Heildelberg, v.10, p. 135-156, 1992.

OVREAS, L.; JENSEN, S.; DAAE, F.L.; TORSVIK, V. Microbial community changes in a perturbed agricultural soil investigated by molecular and physiological approaches. Applied and Environmental Microbiology, Baltimore, v. 64, p.2739-2742, 1998.

PABST, E. Critérios de distinção entre terra preta e latossolo na região de Belterra e os seus significados para a discussão pedogenética. Boletim do Museu Paraense Emílio Goeldi. Série Antropologia, Belém, v. 7, p. 5-19, 1992.

PACE, N.R. A molecular view of microbial diversity and the biosphere. SCIENCE, Washington, v. 276, p.734-740, 1997.

PAGE, W.J.; VONTIGERSTROM, M. Aminochelin, a catecholamine siderophore produced by Azotobacter vinelandii. Journal of General Microbiology, Reading, v.134, p.453-460, 1988.

PAITAN, Y.; ALON, G.; ORR, E.; RON, E.Z.; ROSENBERG, E. The first gene in the biosynthesis of the polyketide antibiotic TA of Myxococcus xanthus codes for a unique PKS module coupled to a peptide synthetase. Journal Molecular Biology, London, v.286, p.465474, 1999.

PATRIARCA, E.J.; TATÈ, R.; IACCARINO, M..Key Role of Bacterial $\mathrm{NH}_{4}{ }^{+}$metabolism in Rhizobium-Plant Symbiosis. Microbiology and Molecular Biology Review, Washington, v. 66, p.203-222, 2002.

PAVLI, V.; SOKOLIC, M. Comparative determination of bacitracin by HPLC and microbiological methods in some pharmaceuticals and feed grade preparations. Journal of Liquid Chromatography, New York, v.13, n.2, p.303-318, 1990.

PAYNE, S.M. Detection, isolation and characterization of siderophores. Methods in Enzymology, New York, v. 235, p. 329-344, 1994.

PERSMARK, M.; EXPERT, D.; NEILANDS, J.B. Isolation, characterization, and synthesis of chrysobactin, a compound with siderophore activity from erwinia-chrysanthemi. Journal of Biological Chemistry, Baltimore, v.264, p.3187-3193, 1989. 
POLE, K.; YOUNG, L.; NESSHAT, S. Enterobactin-mediated iron transport in Pseudomonas aeruginosa. Journal of Bacteriology, Baltimore, v.172, p.6991-6996, 1990.

POPPE, K.; TARAZ, K.; BUDZIKIEWICZ, H. Pyoverdine Type Siderophores from Pseudomonas fluorescens. Tetrahedron, London, v.43, p.2261-2272, 1987.

QUADRI, L.E.N.; KEATING, T.A.; PATEL, H. M.; WALSH, C.T. Assembly of the Pseudomonas aeruginosa nonribosomal peptide siderophore pyochelin: In vitro reconstitution of aryl-4,2-bisthiazoline synthetase activity from PchD, PchE, and PchF. Biochemistry, v. 38, p. 14941-14954, 1999.

RABSCH, W.; VOIGT, W.; REISSBRODT, R.; TTSOLIS, R.M.; BAUMLER, A.J. Salmonella typhimirium tron and fepa proteins mediated uptake of enterobactin but differ in their specificity for other siderophores. Journal of Bacteriology, Baltimore, v.181, p. 36103612. 1999.

RABSCH, W.; METHNER, U.; VOIGT, W. Role of receptor proteins for enterobactin and 2,3-dihydroxybenzoylserine in virulence of Salmonella enterica Infection and Immunity, Baltimore, v. 71, p.6953-6961, 2003.

RAJKUMAR, M.; NAGENDRAN, R.; LEE, K.; LEE, W. H.; KIM, S.Z. Influence of plant growth promoting bacteria and $\mathrm{Cr} 6+$ on the growth of Indian mustard. Chemosphere, Oxford, v.62, p.741-748, 2006.

ROMBEL, I.T; McMORRAN, B.J.; LAMONT, I L. Identification of a DNA sequence motif required for expression of iron-regulated genes in pseudomonads. Molecular and General Genetics, Heidelberg, v.246, p.519-528, 1995.

RONDON, M.R.; GOODMAN, R.M.; HANDELSMAN, J. The Earth's bounty: assessing and accessing soil microbial diversity. Trends in Biotechnology, Cambridge, v. 17, p. 403-409, 1999.

RONDON, M.R.; AUGUST, P.R.; BETTERMANN, A.D.; BRADY, S.F.; GROSSMAN, T.H.; LILES, M.R.; LOIACONO, K.A.; LYNCH, B.A.; MACNEIL, I.A.; MINOR, C.; TIONG, C.L.; GILMAN, M.; OSBURNE, M.S.; CLARDY, J.; HANDELSMAN, J.; GOODMAN, R.M. Cloning the soil metagenome: a strategy for accessing the genetic and functional diversity of uncultured microorganisms. Applied and Environmental Microbiology, Baltimore, vol. 66, p. 2541-2547, 2000. 
RONDON M.R., BALLERING K.S.; THOMAS M.G. Identification and analysis of a siderophore biosynthetic gene cluster from Agrobacterium tumefaciens C58. Microbiology, Reading, v.150, p.3857-3866, 2004.

SÁ, E.L.S. Diversidade fenotípica e genética de rizóbios isolados de feijoeiro (Phaseolus vulgaris) em solos ácidos de Cunha-SP. p. Tese (Doutorado em Ciências) - Centro de Energia Nuclear na Agricultura, Universidade de São Paulo, Piracicaba, 109 f., 2001.

SAITOU, N.; NEI, M. The neighbour-joining method: a new method for reconstructing phylogenetic trees. Molecular Biology and Evolution, Chicago, v. 4, p. 406-425, 1987.

SCHWYN, B.; NEILANDS, J.B. Universal chemical assay for the detection and determination of siderophores. Analytical Biochemistry, New York, v. 160, p. 47-56, 1987.

SILAKOWSKI, B.; SCHAIRER, H.U.; EHRET, H.; KUNZE, B.; WEINIG, S.; NORDSIEK, G.; BRANDT, P.; BLOCKER, H.; HO£E, G.; BEYER, S.; MULLER, R. New lessons for combinatorial biosynthesis from myxobacteria. The myxothiazol biosynthetic gene cluster of Stigmatella aurantiaca dw4/3-1. Journal Biological Chemistry, Baltimore, v. 274, p.3739137399, 1999.

SILVA-STENICO, M.E.; PACHECO, F.T.H.; CARRILHO, E.; RODRIGUES, J.L.M.; TSAI, S.M. Growth and siderophore production of Xylella fastidiosa under iron-limited condition. Microbiological Research, Amsterdam, v. 160, n. 4, p. 429-436, 2005.

SIN, D.W.-M.; WONG, Y.-C. Analytical methodologies for identifying a polypeptide antibiotic. Trends in Analytical Chemistry, Amsterdam, vol. 22, p.799-809, 2003.

SIN, D.W.-M.; HO, C.; WONG, Y.-C.; HO, S.-K.; CHUN-BONG IP, A. Analysis of major components of residual bacitracin and colistin in food samples by liquid chromatography tandem mass spectrometry. Analytica Chimica Acta, Amsterdam, v.535, n. 1-2, p.23-31, 2005 .

SMITH, N.J.H. Anthrosols and human carrying capacity in Amazonia. Annals of the Association of American Geographers, Washington, v. 70, p. 553-566, 1980.

SMITH, M.J.; SHOOLERY, J.N.; SCHWYN, B. Rhizobactin, a structurally novel siderophore from Rhizobium meliloti. Journal of the American Chemical Society, Salt Lake City, v.107, p.1739-1743, 1985.

SMITH, J.J.; TOW, L.A.; STAFFORD, W.; CARY, C.; COWA, D.A. Bacterial diversity in three different Antarctic cold desert mineral soils. Microbial Ecology, New York, v. 51, n. 4, p. 413-421, 2006. 
SOMBROEK, W.G. Amazon Soils: A reconnaissance of the soils of the Brazilian Amazon region. Wageningen: Center for Agricultural Publications and Documentation, 1966.

STACHELHAUSS, T.; MARAHIEL, E. Modular structure of genes encoding multifuncional peptide synthetases required for non-ribosomal peptide synthesis. FEMS Microbiology Letters, Amsterdam, v. 125, p. 3-14, 1995.

STACHELHAUSS, T.; SCNEIDER, A.; MARAHIEL, E. Engineered biosynthesis of peptide antibiotics. Biochemical Pharmacology, London, v. 52, p. 177-186, 1996.

STELLER, S.; VOLLENBROICH, D.; LEENDERS, F. Structural and functional organization of the fengycin synthetase multienzyme system from Bacillus subtilis b213 and A1/3 Chemistry \& Biology, Tokyo, v.6, p.31-41, 1999.

SWOFFORD, D.; OLSEN, G.; WADDEL, P.; HILLIS, M. Phylogenetic inference. In: HILliS, D.M.; MORTIZ, C.; MABLE, B.K. (Ed.). Molecular Systematics. $2^{\mathrm{a}}$ ed. Sunderland: Sinauer Association, 1996. p. 407-514.

TEINTZE, M.; LEONG, J.; HOSSAIN, M.B.; BARNES, C.L.; VANDERHELM, D. Structure of ferric pseudobactin - a siderophore from a plant growth-promoting pseudomonas. Phytopathology, Lancaster, v.71, p.908-908, 1981.

THOMASHOW, L.S.; WELLER, D.M.; BONSALL, R.F. Production of the antibiotic phenazine-1-carboxylic acid by fluorescent pseudomonas species in the rhizosphere of wheat. Applied and Environmental Microbiology, Baltimore, v.56, p.908-912, 1990.

THOMPSON, J.D.; HIGGINS, D.G.; GIBSON, T.J.; CLUSTAL, W. Improving the sensitivity of progressive multiple sequence alignment through sequence weighting, position specific-gap penalties and weigh matrix choice. Nucleic Acids Research, London, v. 22, p. 4673-4680, 1994.

TORSVIK, V.; OVREAS, L.; THINGSTAD, T. F. Prokaryotic diversity--magnitude, dynamics, and controlling factors. Science, Washington, v.296, p.1064-1066, 2002.

TORTORA, G. J.; FUNKE, B. R.; CASE, C.L. Microbiologia. In: Genética Microbiana. $8^{\text {a }}$ ed. São Paulo: Artmed Editora, 2005. p. 210-247.

TRIPATHI, M.; MUNOT, H. P.; SHOUCHE, Y.; MEYER, J. M.; GOEL, R. Isolation and functional characterization of siderophore-producing lead- and cadmium-resistant Pseudomonas putida KNP9. Current Microbiology, New York, v.50, p.233-237, 2005. 
VAN-WAGENINGEN, A.M.A.; KIRKPATRICK, P.N.; WILLIAMS, D.H.; HARRIS, B.R.; KERSHAW, J.K.; LENNARD, N.J.; JONES, M.; JONES, S.J.M.; SOLENBERG, P.J. Sequencing and analysis of genes involved in the biosynthesis of a vancomycin group antibiotic. Chemical Biology, London, v.5, p.155-162, 1998.

VENTER, J.C.; REMINGTON, K.; HEIDELBERG, J.F.; HALPERN, A.L.; RUSCH, D.; EISEN, J.A.; WU, D.Y.; PAULSEN, I.; NELSON, K.E.; NELSON, W.; FOUTS, D.E.; LEVY, S.; KNAP, A.H.; LOMAS, M.W.; NEALSON, K.; WHITE, O.; PETERSON, J.; HOFFMAN, J.; PARSONS, R.; BADEN-TILLSON, H.; PFANNKOCH, C.; ROGERS, Y.H.; SMITH, H. O. Environmental genome shotgun sequencing of the sargasso sea. Science, Washington, v. 304, p. 66-74, 2004.

VINCENT, J.M. Manual for the Practical Study of Root Nodule Bacteria. Oxford: Blackwell, Oxford, 1970. (IBP Handbook, 15).

WAWRIK, B.; KERKHOF, L.; ZYLSTRA, J.; KUKOR, J.J. Identification of unique type II polyketide synthase genes in soil. Applied and Environmental Microbiology, Baltimore, v. 71, p. 2232-2238, 2005.

WEI, H. L., ZHANG, L. Q. Quorum-sensing system influences root colonization and biological control ability in Pseudomonas fluorescens 2P24. Antonie van Leeuwenhoek. Dordrecht, v.89, p. $267-280,2006$.

WEISBURG, W.G.; BARNS, S.M.; PELLETIER, D.A.; GENE-TRAK, D.J.L. $16 \mathrm{~S}$ ribossomal DNA amplification for phylogenetic study. Journal of Bacteriology, Baltimore, v. 173, n. 2, p. 697-703, 1991.

WILliAMS, C.; PATEL, I.; WILlER, C.J.; CROSBY, N.T. Competitive enzyme-linkedimmunosorbent-assay for the determination of zinc bacitracin in animal feedingstuffs. Analyst, Cambridge, v.119, n.3, p.427-430, 1994.

WOESE, C.R., KANDLER, O.; WHEELIS, M.L.. 1990. Towards a natural system of organisms: proposal for the domains Archaea, Bacteria, and Eucarya. Proceedings of the National Academy of Sciences of the USA, Washington, 87:4576-4579.

XIE, X.; WANG, J.; YUAN, H. High-resolution analysis of catechol-type siderophores using polyamide thin layer chromatography. Journal of Microbiological Methods, Amsterdam, v.67, p.390-393, 2006.

XU, J. Microbial ecology in the age of genomics and metagenomics: concepts, tools, and recent advances. Molecular Ecology, New York, v.15, p. 1713-1731, 2006. 
ZHANG, J.H.; QUIGLEY, N.B.; GROSS, D.C. Analysis of the $s y r B$ and $s y r C$ genes of Psuedomonas syringae PV syringae indicates that syringomycin is synthesised by a thiotemplate mechanism. Journal of Bacteriology, Baltimore, v.177, p. 4009-4020, 1995. 